Supporting Information

\title{
Identification of an $\alpha$-Oxoamine Synthase and a One-Pot Two-Step Enzymatic Synthesis of $\alpha$-Amino Ketones
}

Ting Zhou, ${ }^{\ddagger a, b}$ Du Gao, ${ }^{\ddagger a}$, b Jia-Xin Li, ${ }^{b}$ Min-Juan $\mathrm{Xu},{ }^{\mathrm{b}}$ and Jun $\mathrm{Xu}{ }^{* a}$

aState Key Laboratory of Microbial Metabolism, School of Life Sciences and Biotechnology, Shanghai Jiao Tong University, Shanghai 200240, P. R. China.

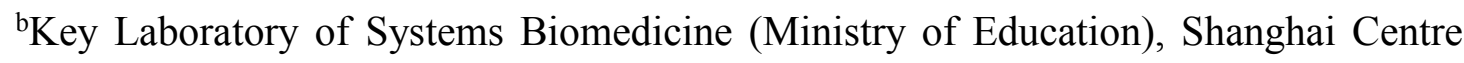
for Systems Biomedicine, Shanghai Jiao Tong University, Shanghai 200240, P. R. China.

$\ddagger$ T. Z. and D. G. contributed equally to this work.

Correspondence and requests could be addressed to J.X. (email: xujunn@sjtu.edu.cn) 


\section{Table of Contents}

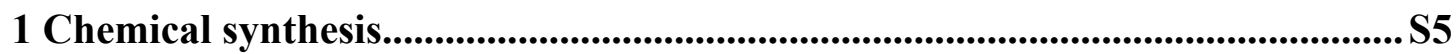

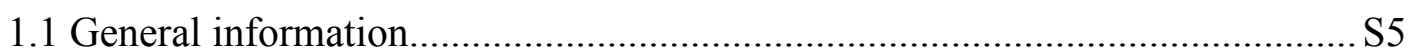

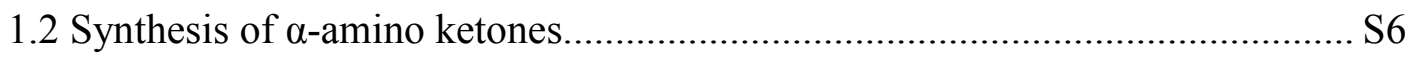

$1.3{ }^{1} \mathrm{H}$ NMR and ${ }^{13} \mathrm{C}$ NMR spectra of compounds............................................. S15

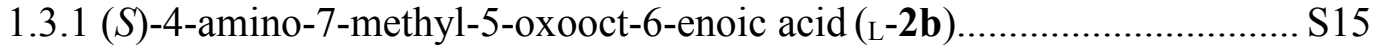

1.3.2 (R)-4-amino-7-methyl-5-oxooct-6-enoic acid (D-2b)............................ S18

1.3.3 (S)-4-amino-5-oxonon-8-enoic acid (L-7b) ....................................... S22

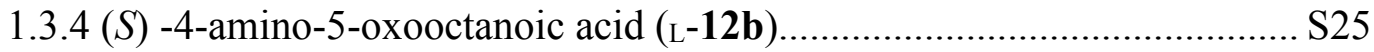

1.3.5 (S)-4-amino-5-oxononanoic acid (L-13b) ........................................... S29

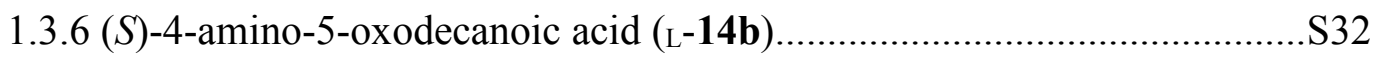

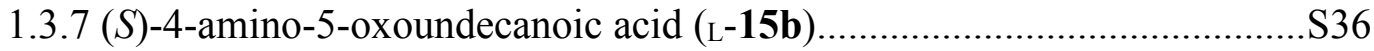

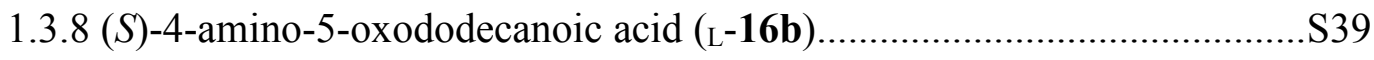

2 Supporting methods..............................................................................................543

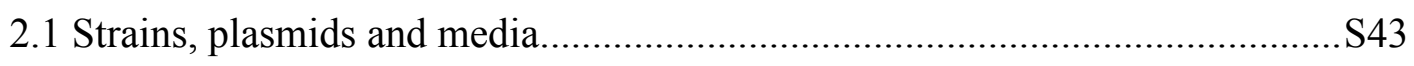

2.2 DNA manipulation and sequence analysis.............................................. S43

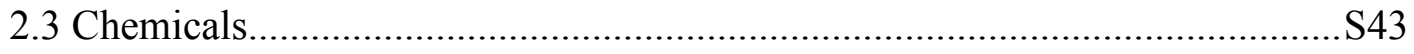

2.4 Gene inactivation, complementation and metabolites analysis..................... S44

2.5 Multiple sequence alignment and phylogenetic analysis............................... S45

2.6 Cloning, expression and purification of recombinant proteins.......................S46

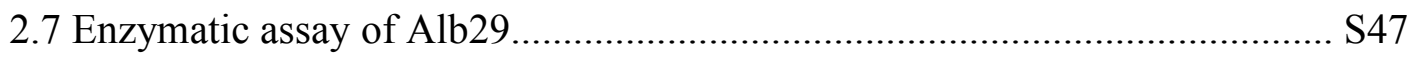

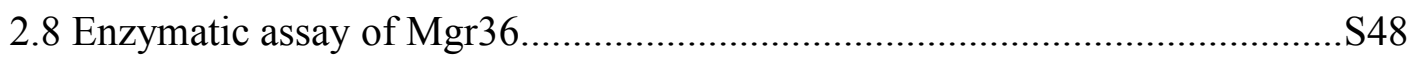

2.9 In vitro assay of one-pot two-step cascade reaction with Alb29 and Mgr36...S48

2.10 Derivatization of $\alpha$-amino ketones with Marfey's reagent........................... S48

2.11 Time-course analysis of $\mathbf{2 b}$, based on Marfey's reagent derivatization........ S49

2.12 Effects of temperature and buffer on the racemization of ${ }_{L}-\mathbf{2 b}$.................... S50

2.13 The analysis of Alb29 ultraviolet-visible spectra..................................... S50

2.14 Effect of $\mathrm{pH}$ on Alb29 enzymatic activity................................................ S5

2.15 Effect of temperature on Alb29 enzymatic activity................................... S51

2.16 Kinetic analyses of Alb29 towards ${ }_{L}-G l u, 2 a, 3 a, 4 a, 12 a, 14 a$ and 16a.......S51

2.17 The yields of products $\mathbf{2 b}, \mathbf{7 b}$, and $\mathbf{1 2 b}-\mathbf{1 6} \mathbf{b}$ in one-pot two-step cascade reaction. 
Figure S1. Multiple sequence alignment of Alb29.

Figure S2. Construction of the $\Delta$ alb29 mutant and alb29 complementation strain

Figure S3. Purification of $\mathrm{N}$-His 6 tagged Alb29.

Figure S4. HRMS (ESI-) spectra of Alb29-generated products.

Figure S5. The FDAA derivatives of $\mathbf{2 b}$ under different reaction conditions S61

Figure S6. Time-course analysis of enzymatic products taking L-2b-FDAA and D-2b-FDAA as authentic standards. S62

Figure S7. Effects of temperature and buffer on the racemization of $\mathrm{L}_{\mathrm{L}} \mathbf{- 2} \mathbf{b}$. S63

Figure S8. The UV-vis spectra of Alb29.... S64

Figure S9. The proposed mechanism of Claisen-like condensation catalyzed by Alb2911 S65

Figure S10. Phylogenetic analysis of Alb29. S66

Figure S11. SDS-PAGE analysis of purified N-His6 tagged Mgr36. S67

Figure S12. In vitro biochemical assays of Mgr36 with different substrates. S68

Figure S13. HRMS (ESI-) analysis of the Mgr36-generated acyl-CoA products (2a-16a, 20a-22a). S70

Figure S14. UPLC-MS analysis of the $\alpha$-ketoamine products from one-pot reaction S72

Figure S15. HRMS (ESI-) analysis of the $\alpha$-ketoamine products in stable isotope labeling experiments using $\mathrm{L}^{-13} \mathrm{C}_{5},{ }^{15} \mathrm{~N}$-glutamate in one-pot reaction. S73 Figure S16. HPLC analysis of the FDAA derivatives of the $\alpha$-ketoamine products from one-pot reaction. S74

Figure S17. Effect of $\mathrm{pH}$ on Alb29 activity.... S75

Figure S18. Effect of temperature on Alb29 activity..... S76

Figure S19. Kinetic parameters determination of Alb29 towards L-Glu and acyl-CoAs $2 \mathbf{a}, 3 \mathbf{3}, \mathbf{4 a}, \mathbf{1 2 a}, \mathbf{1 4} \mathbf{a}$ and 16a. S77

Figure S20. The UV-vis spectra of new albogrisin analogs S78

Figure S21. HRMS (ESI-) spectra of albogrisin analogs in stable isotope labeling experiments. S79 
Figure S22. Separation of albogrisin B (1) and $\mathrm{B}^{\prime}\left(\mathbf{1}^{\prime}\right)$ together with its analogs $\left(3 \mathbf{c} / \mathbf{3} \mathbf{c}^{\prime}, 7 \mathbf{c} / 7 \mathbf{c}^{\prime}, \mathbf{1 2 c} / \mathbf{1 2} \mathbf{c}^{\prime}\right)$ by SFC S80

Figure S23. (-) ESI-MS/MS fragmentations of albogrisin analogs by ionization of $[\mathrm{M}-\mathrm{H}]^{-}$and proposed mechanism. S84

Figure S24. The proposed structures of $\mathbf{3 c} / \mathbf{3} \mathbf{c}^{\prime}, \mathbf{7} \mathbf{c} / \mathbf{7} \mathbf{c}^{\prime}$ and $\mathbf{1 2 c} / \mathbf{1 2} \mathbf{c}^{\prime}$ S85 Figure S25. The standard curve showing the absorbance $(412 \mathrm{~nm})$ of different HS-CoA concentrations S86

Figure S26. The standard curves representing the relationship between the peak response value of UPLC-APCI-HRMS and different concentrations of $\mathbf{2 b}, \mathbf{7 b}$ and 12b-16b S87

\section{Supporting Tables.} S88

Table S1. The members of the $\alpha$-oxoamine synthases family found as stand-alone enzymes or components of multi-domain synthases S88

Table S2. The DNA sequence of alb29 and the amino acid sequence of Alb29... S89 Table S3. Amino acid sequence identity between Alb29 and other $\alpha$-oxoamine synthases $^{a}$ S90

Table S4. The DNA sequence of $m g r 36$ and the amino acid sequence of Mgr36.. S91

Table S5. HRMS data of the Mgr36-generated acyl-CoA products. S92

Table S6. HRMS data of the products synthesized by one-pot reaction of Mgr36 and Alb29 S93

Table S7. HRMS data and ratio of the FDAA derivatives of $\mathbf{2} \mathbf{b}$ analogs. S94

Table S8. Kinetic properties of Alb29. S95

Table S9. HRMS data of the new albogrisin analogs. S96

Table S10. The SFC-MS/MS fragment ions of albogrisin analogs in the negative mode.

Table S11. Strains and plasmids used in this study S100

Table S12. Primers used in this study and their sequence. S101

Table S13. The DNA sequence containing the promoter of orf 2284 . S102 Table S14. The accession numbers of the known AOSs used for phylogenetic analysis of Alb29 S103

References. $\mathbf{S 1 0 4}$ 


\section{Chemical synthesis}

\subsection{General information}

All reagents were used as received unless otherwise noted. Reactions were carried out under a nitrogen atmosphere unless otherwise noted. Reactions were monitored by thin layer chromatography using Merck Silica Gel 60 F254 (USA) precoated silica TLC plates $(0.25 \mathrm{~mm})$ which were visualized using UV, p-anisaldehyde, or iodine stain. Flash column chromatography was performed using 300-400 mesh silica gel. Preparative TLC $(0.9-1.0 \mathrm{~mm})$ was conducted with glass-precoated silica gel HSGF254 (Yantai, P. R. China). 5-OtBu- $N$-Boc-protected L-glutamate and 5-OtBu- $N$-Boc-protected D-glutamate were purchased from Shanghai Bide Pharmatech Ltd. (Shanghai, P. R. China). The other chemical reagents used for chemical synthesis were purchased from Shanghai Aladdin Biochemical Technology Co., Ltd. (Shanghai, P. R. China). Analytical High-performance liquid chromatography (HPLC) was carried out on an Agilent Extend-C18 column $(4.6 \times$ $150 \mathrm{~mm}, 5 \mu \mathrm{m})$, flow $1 \mathrm{~mL} / \mathrm{min}$, and UV detection. ${ }^{1} \mathrm{H}$ and ${ }^{13} \mathrm{C}$ NMR spectra were recorded with an Avance III $600 \mathrm{MHz}$ NMR spectroscopic (Bruker). The NMR spectra were recorded in DMSO- $d_{6}$ solution, chemical shifts were referenced to residual solvent signals $\left(\delta_{H} 2.49 / \delta_{C} 39.6\right.$ for DMSO- $\left.d_{6}\right)$. Optical rotations were measured in $\mathrm{MeOH}$ on a Jasco P-2000 polarimeter. High resolution mass spectrometry (HRMS) spectra were measured using a Waters ACQUITY ultra-performance liquid chromatography (UPLC) system equipped with a Micromass Q-TOF Premier mass spectrometer (Waters MS Technologies, Manchester, UK). 


\subsection{Synthesis of $\alpha$-amino ketones}<smiles>CN(C)C(=O)[C@H](N)CCC(=O)OC(C)(C)C</smiles>

S1<smiles>CON(C)C(=O)[C@H](N)CCC(=O)OC(C)(C)C</smiles>

S2

5-OtBu- $N$-Boc-protected L-glutamate Weinreb amide (S1) was synthesized from 5-OtBu- $N$-Boc-protected L-glutamate and 5-OtBu- $N$-Boc-protected D-glutamate Weinreb amide (S2) was synthesized from 5-OtBu- $N$-Boc-protected D-glutamate, respectively, according to the procedure described by Ducrot et al. ${ }^{1}$ Compounds S1 and $\mathbf{S 2}$ were confirmed by ultra-performance liquid chromatography-high resolution mass spectrometry (UPLC-HRMS). The synthetic methods of the following compounds were slightly modified, based on the procedure described by Chun and Tian et al. ${ }^{2}$

\section{OtBu- $N$-Boc-protected L-glutamate 2-methyl-1-propenyl ketone (S3):}

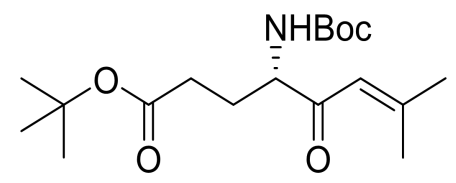

S3

To a solution of 5-OtBu- $N$-Boc-protected L-glutamate Weinreb amide (S1, $140 \mathrm{mg}$, $0.405 \mathrm{mmol}, 1.0$ equiv) dissolved in tetrahydrofuran (THF, $2 \mathrm{~mL}$ ) was added a $0.5 \mathrm{M}$ solution of 2-methyl-1-propenyl magnesium bromide in THF (4.8 mL, $2.4 \mathrm{mmol}, 5.93$ equiv) at $-20{ }^{\circ} \mathrm{C}$. After stirring for $12 \mathrm{~h}$ at the same temperature, the reaction was poured into $4 \mathrm{~mL}$ of saturated $\mathrm{NH}_{4} \mathrm{Cl}$. The aqueous phase was extracted with EtOAc (3x). The organic layers were combined, washed with brine, dried over $\mathrm{Na}_{2} \mathrm{SO}_{4}$, filtered, and evaporated under reduced pressure to afford an oil. The crude residue was purified by preparative TLC (8:1 hexanes/EtOAc v/v) to afford $50.6 \mathrm{mg}$ of the title compound (36.6\% yield) as a light yellow oil.

S3: $\mathrm{R}_{f}=0.4(4: 1$ hexanes/EtOAc $\mathrm{v} / \mathrm{v}) ;$ HRMS (ESI) $\mathrm{m} / \mathrm{z}$ calculated for $\mathrm{C}_{18} \mathrm{H}_{31} \mathrm{NO}_{5} \mathrm{Na}^{+}[\mathrm{M}+\mathrm{Na}]^{+}$364.2100, found 364.2086. 


\section{(S)-4-amino-7-methyl-5-oxooct-6-enoic acid ( $\mathrm{L}-2 \mathrm{~b})$ :}<smiles>CC(C)=CC(=O)[C@@H](N)CCC(=O)O</smiles>

To a solution of OtBu- $N$-Boc-protected L-glutamate 2-methyl-1-propenyl ketone (S3, $34.1 \mathrm{mg}, 0.1 \mathrm{mmol}, 1.0$ equiv) dissolved in dichloromethane (DCM, $3 \mathrm{~mL}$ ) was added trifluoroacetic acid (TFA, $3 \mathrm{~mL}$ ) at room temperature (rt). After stirring for $3 \mathrm{~h}$, the reaction was concentrated by rotary evaporation. The residue was twice taken up in DCM and concentrated to remove TFA to afford $24.4 \mathrm{mg}$ of the title compound as a TFA salt with minor impurities (81.6\% yield) as a brown oil.

L-2b: $\mathrm{R}_{f}=0.1\left(1: 2\right.$ hexanes/EtOAc v/v); $[\alpha]_{\mathrm{D}}^{24}+69.5($ c $0.00164 \mathrm{~g} / \mathrm{mL}, \mathrm{MeOH})$; HRMS (ESI) $m / z$ calculated for $\mathrm{C}_{9} \mathrm{H}_{14} \mathrm{NO}_{3}{ }^{-}[\mathrm{M}-\mathrm{H}]^{-}$184.0974, found $184.0981 .{ }^{1} \mathrm{H}$ NMR and ${ }^{13} \mathrm{C}$ NMR data have been showed in $\mathbf{1 . 3}$.

\section{OtBu- $N$-Boc-protected D-glutamate 2-methyl-1-propenyl ketone (S4):}<smiles>CC(C)=CC(=O)C(CCC(=O)OC(C)(C)C)NC(C)C</smiles>

S4

To a solution of 5-OtBu- $N$-Boc-protected $\mathrm{D}_{\text {-glutamate }}$ Weinreb amide (S2, $175 \mathrm{mg}$, $0.506 \mathrm{mmol}, 1.0$ equiv) dissolved in THF $(2 \mathrm{~mL})$ was added a $0.5 \mathrm{M}$ solution of 2-methyl-1-propenyl magnesium bromide in THF (4.8 mL, $2.4 \mathrm{mmol}, 4.74$ equiv) at $-20{ }^{\circ} \mathrm{C}$. After stirring for $12 \mathrm{~h}$ at the same temperature, the reaction was poured into 4 $\mathrm{mL}$ of saturated $\mathrm{NH}_{4} \mathrm{Cl}$. The aqueous phase was extracted with EtOAc (3x). The organic layers were combined, washed with brine, dried over $\mathrm{Na}_{2} \mathrm{SO}_{4}$, filtered, and evaporated under reduced pressure to afford an oil. The crude residue was purified by preparative TLC $(8: 1$ hexanes/EtOAc $\mathrm{v} / \mathrm{v})$ to afford $71.0 \mathrm{mg}$ of the title compound (41.1\% yield) as a light yellow oil. 
S4: $\mathrm{R}_{f}=0.4(4: 1$ hexanes/EtOAc $\mathrm{v} / \mathrm{v}) ;$ HRMS (ESI) $\mathrm{m} / \mathrm{z}$ calculated for $\mathrm{C}_{18} \mathrm{H}_{31} \mathrm{NO}_{5} \mathrm{Na}^{+}[\mathrm{M}+\mathrm{Na}]^{+}$364.2100, found 364.2091.

(R)-4-amino-7-methyl-5-oxooct-6-enoic acid ( $\mathrm{D}-2 \mathrm{~b})$ :<smiles>CC(C)=CC(=O)[C@@H](N)CCC(=O)O</smiles>

To a solution of OtBu- $N$-Boc-protected D-glutamate 2-methyl-1-propenyl ketone (S4, $45.4 \mathrm{mg}, 0.133 \mathrm{mmol}, 1.0$ equiv) dissolved in DCM (4 mL) was added TFA (4 $\mathrm{mL}$ ) at $\mathrm{rt}$. After stirring for $3 \mathrm{~h}$, the reaction was concentrated by rotary evaporation. The residue was twice taken up in DCM and concentrated to remove TFA to afford $26.7 \mathrm{mg}$ of the title compound as a TFA salt with minor impurities (67.1\% yield) as a brown oil.

D-2b: $\mathrm{R}_{f}=0.1(1: 2$ hexanes/EtOAc $\mathrm{v} / \mathrm{v}) ;[\alpha]_{\mathrm{D}}^{24}-72.1(c 0.00113 \mathrm{~g} / \mathrm{mL}, \mathrm{MeOH}) ;$ HRMS (ESI) $m / z$ calculated for $\mathrm{C}_{9} \mathrm{H}_{14} \mathrm{NO}_{3}{ }^{-}[\mathrm{M}-\mathrm{H}]^{-}$184.0974, found 184.0981. ${ }^{1} \mathrm{H}$ NMR and ${ }^{13} \mathrm{C}$ NMR data have been showed in $\mathbf{1 . 3}$.

\section{OtBu- $N$-Boc-protected L-glutamate 3-butenyl ketone (S5):}

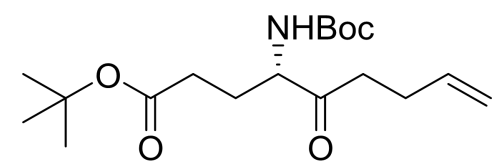

S5

To a solution of 5-OtBu- $N$-Boc-protected $\mathrm{L}$-glutamate Weinreb amide (S1, $45 \mathrm{mg}$, $0.13 \mathrm{mmol}, 1.0$ equiv) dissolved in THF $(1.5 \mathrm{~mL})$ was added a $0.5 \mathrm{M}$ solution of 3-butenyl magnesium bromide in THF (3.6 mL, $1.8 \mathrm{mmol}, 13.8$ equiv) at $-20{ }^{\circ} \mathrm{C}$. After stirring for $24 \mathrm{~h}$ at the same temperature, the reaction was poured into $5 \mathrm{~mL}$ of saturated $\mathrm{NH}_{4} \mathrm{Cl}$. The aqueous phase was extracted with EtOAc (3x). The organic layers were combined, washed with brine, dried over $\mathrm{Na}_{2} \mathrm{SO}_{4}$, filtered, and evaporated under reduced pressure to afford an oil. The crude residue was purified by preparative 
TLC (6:1 hexanes/EtOAc v/v) to afford $16.6 \mathrm{mg}$ of the title compound (37.4\% yield) as an oil.

S5: $\mathrm{R}_{f}=0.6(4: 1$ hexanes/EtOAc $\mathrm{v} / \mathrm{v}) ;$ HRMS (ESI) $\mathrm{m} / \mathrm{z}$ calculated for $\mathrm{C}_{18} \mathrm{H}_{31} \mathrm{NO}_{5} \mathrm{Na}^{+}[\mathrm{M}+\mathrm{Na}]^{+}$364.2100, found 364.2081.

(S)-4-amino-5-oxonon-8-enoic acid ( $L-7 b)$ :<smiles>C=CCCC(=O)[C@H](N)CCC(=O)O</smiles>

To a solution of OtBu- $N$-Boc-protected L-glutamate 3-butenyl ketone (S5, $16.6 \mathrm{mg}$, 0.049 mmol, 1.0 equiv) dissolved in DCM (2 mL) was added TFA (2 mL) at rt. After stirring for $3 \mathrm{~h}$, the reaction was concentrated by rotary evaporation. The residue was twice taken up in DCM and concentrated to remove TFA to afford $14.4 \mathrm{mg}$ of the title compound as a TFA salt with minor impurities (98.3\% yield) as an oil.

$\mathbf{L}-7 \mathbf{b}:[\alpha]_{\mathrm{D}}^{25}+25.5(c \quad 0.001 \mathrm{~g} / \mathrm{mL}, \mathrm{MeOH})$; HRMS (ESI) $\mathrm{m} / z$ calculated for $\mathrm{C}_{9} \mathrm{H}_{14} \mathrm{NO}_{3}{ }^{-}[\mathrm{M}-\mathrm{H}]^{-}$184.0974, found 184.0978. ${ }^{1} \mathrm{H} \mathrm{NMR}$ and ${ }^{13} \mathrm{C} \mathrm{NMR}$ data have been showed in 1.3.

OtBu-N-Boc-protected L-glutamate propyl ketone (S6):

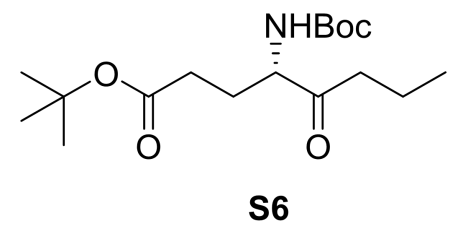

To a solution of 5-OtBu- $N$-Boc-protected ${ }_{\mathrm{L}}$-glutamate Weinreb amide (S1, $90 \mathrm{mg}$, $0.26 \mathrm{mmol}, 1.0$ equiv) dissolved in THF $(8.4 \mathrm{~mL})$ was added a $2 \mathrm{M}$ solution of propyl mangesium chloride in THF $(1.8 \mathrm{~mL}, 3.6 \mathrm{mmol}, 13.8$ equiv $)$ at $-20{ }^{\circ} \mathrm{C}$. After stirring for $24 \mathrm{~h}$ at the same temperature, the reaction was poured into $10 \mathrm{~mL}$ of saturated $\mathrm{NH}_{4} \mathrm{Cl}$. The aqueous phase was extracted with EtOAc $(3 \mathrm{x})$. The organic layers were combined, washed with brine, dried over $\mathrm{Na}_{2} \mathrm{SO}_{4}$, filtered, and evaporated under 
reduced pressure to afford an oil. The crude residue was purified by preparative TLC (8:1 hexanes/EtOAc v/v) to afford $8.9 \mathrm{mg}$ of the title compound (10.4\% yield) as an oil.

S6: $\mathrm{R}_{f}=0.3(6: 1$ hexanes/EtOAc $\mathrm{v} / \mathrm{v}) ;$ HRMS (ESI) $\mathrm{m} / \mathrm{z}$ calculated for $\mathrm{C}_{17} \mathrm{H}_{31} \mathrm{NO}_{5} \mathrm{Na}^{+}[\mathrm{M}+\mathrm{Na}]^{+}$352.2100, found 352.2098.

\section{(S)-4-amino-5-oxooctanoic acid ( $\mathrm{L}-12 \mathrm{~b})$ :}<smiles>CCCC(=O)[C@H](N)[14CH2][14CH3]</smiles>

To a solution of OtBu- $N$-Boc-protected L-glutamate propyl ketone (S6, $8.9 \mathrm{mg}$, 0.027 mmol, 1.0 equiv) dissolved in DCM $(1 \mathrm{~mL})$ was added TFA $(1 \mathrm{~mL})$ at rt. After stirring for $3 \mathrm{~h}$, the reaction was concentrated by rotary evaporation. The residue was twice taken up in DCM and concentrated to remove TFA to afford $6.0 \mathrm{mg}$ of the title compound as a TFA salt with minor impurities (77.4\% yield) as an oil.

L-12b: $\mathrm{R}_{f}=0.1\left(1: 2\right.$ hexanes/EtOAc v/v); $[\alpha]_{\mathrm{D}}^{28}+29.4(c 0.00096 \mathrm{~g} / \mathrm{mL}, \mathrm{MeOH})$; HRMS (ESI) $m / z$ calculated for $\mathrm{C}_{8} \mathrm{H}_{14} \mathrm{NO}_{3}{ }^{-}[\mathrm{M}-\mathrm{H}]^{-}$172.0974, found $172.0981 .{ }^{1} \mathrm{H}$ NMR and ${ }^{13} \mathrm{C}$ NMR data have been showed in $\mathbf{1 . 3}$.

OtBu-N-Boc-protected L-glutamate butyl ketone (S7):

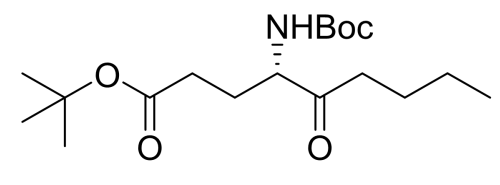

S7

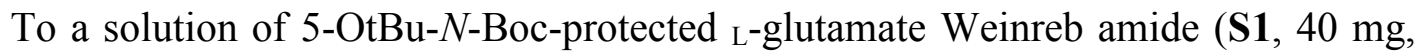
$0.116 \mathrm{mmol}, 1.0$ equiv) dissolved in THF $(4.2 \mathrm{~mL})$ was added a $2 \mathrm{M}$ solution of butyl magnesium chloride in THF ( $0.9 \mathrm{~mL}, 1.8 \mathrm{mmol}, 15.5$ equiv) at $-20{ }^{\circ} \mathrm{C}$. After stirring for $24 \mathrm{~h}$ at the same temperature, the reaction was poured into $5 \mathrm{~mL}$ of saturated $\mathrm{NH}_{4} \mathrm{Cl}$. The aqueous phase was extracted with EtOAc $(3 \mathrm{x})$. The organic layers were 
combined, washed with brine, dried over $\mathrm{Na}_{2} \mathrm{SO}_{4}$, filtered, and evaporated under reduced pressure to afford an oil. The crude residue was purified by preparative TLC (10:1 hexanes/EtOAc v/v) to afford $4.6 \mathrm{mg}$ of the title compound (11.6\% yield) as an oil.

S7: $\mathrm{R}_{f}=0.25(10: 1$ hexanes/EtOAc $\mathrm{v} / \mathrm{v})$; HRMS (ESI) $\mathrm{m} / \mathrm{z}$ calculated for $\mathrm{C}_{18} \mathrm{H}_{33} \mathrm{NO}_{5} \mathrm{Na}^{+}[\mathrm{M}+\mathrm{Na}]^{+}$366.2256, found 366.2242.

\section{(S)-4-amino-5-oxononanoic acid ( $\mathrm{L}-13 \mathrm{~b})$ :}<smiles>CCCCC(=O)[C@H](N)CCC(=O)O</smiles>

To a solution of OtBu- $N$-Boc-protected L-glutamate butyl ketone (S7, 4.6 mg, 0.013 mmol, 1.0 equiv) dissolved in DCM $(1 \mathrm{~mL})$ was added TFA $(1 \mathrm{~mL})$ at $\mathrm{rt}$. After stirring for $3 \mathrm{~h}$, the reaction was concentrated by rotary evaporation. The residue was twice taken up in DCM and concentrated to remove TFA to afford $2.5 \mathrm{mg}$ of the title compound as a TFA salt with minor impurities (63.9\% yield) as an oil.

L-13b: $[\alpha]_{\mathrm{D}}^{28}+37.2(c 0.00075 \mathrm{~g} / \mathrm{mL}, \mathrm{MeOH})$; HRMS (ESI) $m / z$ calculated for $\mathrm{C}_{9} \mathrm{H}_{16} \mathrm{NO}_{3}{ }^{-}[\mathrm{M}-\mathrm{H}]^{-}$186.1130, found 186.1127. ${ }^{1} \mathrm{H} \mathrm{NMR}$ and ${ }^{13} \mathrm{C}$ NMR data have been showed in 1.3.

\section{OtBu- $N$-Boc-protected ${ }_{L}$-glutamate pentyl ketone (S8):}

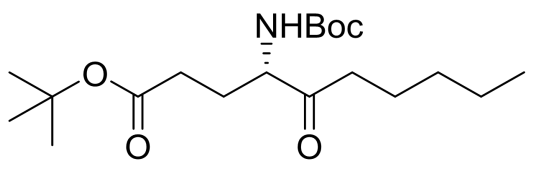

S8

To a solution of 5-OtBu- $N$-Boc-protected ${ }_{\mathrm{L}}$-glutamate Weinreb amide (S1, $40 \mathrm{mg}$, $0.116 \mathrm{mmol}, 1.0$ equiv) dissolved in THF $(3.3 \mathrm{~mL})$ was added a $1 \mathrm{M}$ solution of pentyl magnesium bromide in THF $\left(1.8 \mathrm{~mL}, 1.8 \mathrm{mmol}, 15.5\right.$ equiv) at $-20{ }^{\circ} \mathrm{C}$. After stirring for $24 \mathrm{~h}$ at the same temperature, the reaction was poured into $5 \mathrm{~mL}$ of 
saturated $\mathrm{NH}_{4} \mathrm{Cl}$. The aqueous phase was extracted with EtOAc $(3 \mathrm{x})$. The organic layers were combined, washed with brine, dried over $\mathrm{Na}_{2} \mathrm{SO}_{4}$, filtered, and evaporated under reduced pressure to afford an oil. The crude residue was purified by preparative TLC (10:1 hexanes/EtOAc v/v) to afford $3.9 \mathrm{mg}$ of the title compound ( $9.4 \%$ yield) as an oil.

S8: $\mathrm{R}_{f}=0.27(10: 1$ hexanes/EtOAc $\mathrm{v} / \mathrm{v})$; HRMS (ESI) $\mathrm{m} / \mathrm{z}$ calculated for $\mathrm{C}_{19} \mathrm{H}_{35} \mathrm{NO}_{5} \mathrm{Na}^{+}[\mathrm{M}+\mathrm{Na}]^{+}$380.2413, found 380.2392.

\section{(S)-4-amino-5-oxodecanoic acid (L-14b):}

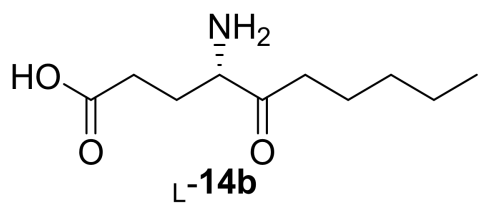

To a solution of OtBu- $N$-Boc-protected L-glutamate pentyl ketone (S8, $3.9 \mathrm{mg}$, $0.011 \mathrm{mmol}, 1.0$ equiv) dissolved in DCM $(1 \mathrm{~mL})$ was added TFA $(1 \mathrm{~mL})$ at $\mathrm{rt}$. After stirring for $3 \mathrm{~h}$, the reaction was concentrated by rotary evaporation. The residue was twice taken up in DCM and concentrated to remove TFA to afford $2.0 \mathrm{mg}$ of the title compound as a TFA salt with minor impurities (57.7\% yield) as an oil.

L-14b: $[\alpha]_{\mathrm{D}}^{28}+26.4(c 0.00079 \mathrm{~g} / \mathrm{mL}, \mathrm{MeOH})$; HRMS (ESI) $\mathrm{m} / \mathrm{z}$ calculated for $\mathrm{C}_{10} \mathrm{H}_{18} \mathrm{NO}_{3}{ }^{-}[\mathrm{M}-\mathrm{H}]^{-}$200.1287, found 200.1285. ${ }^{1} \mathrm{H}$ NMR and ${ }^{13} \mathrm{C}$ NMR data have been showed in 1.3.

\section{OtBu- $N$-Boc-protected L-glutamate hexyl ketone (S9):}

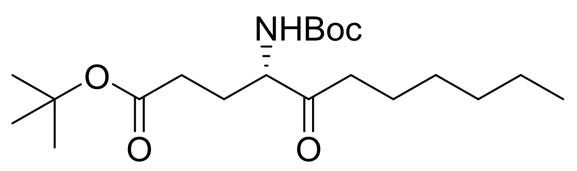

S9

To a solution of 5-OtBu- $N$-Boc-protected L-glutamate Weinreb amide (S1, $80 \mathrm{mg}$, $0.23 \mathrm{mmol}, 1.0$ equiv) dissolved in THF $(6.6 \mathrm{~mL})$ was added a $1 \mathrm{M}$ solution of hexyl magnesium bromide in THF (3.6 mL, $3.6 \mathrm{mmol}, 15.7$ equiv) at $-20{ }^{\circ} \mathrm{C}$. After stirring 
for $24 \mathrm{~h}$ at the same temperature, the reaction was poured into $10 \mathrm{~mL}$ of saturated $\mathrm{NH}_{4} \mathrm{Cl}$. The aqueous phase was extracted with EtOAc (3x). The organic layers were combined, washed with brine, dried over $\mathrm{Na}_{2} \mathrm{SO}_{4}$, filtered, and evaporated under reduced pressure to afford an oil. The crude residue was purified by preparative TLC (10:1 hexanes/EtOAc v/v) to afford $27.8 \mathrm{mg}$ of the title compound (32.6\% yield) as an oil.

S9: $\mathrm{R}_{f}=0.29(10: 1$ hexanes/EtOAc $\mathrm{v} / \mathrm{v})$; HRMS (ESI) $m / z$ calculated for $\mathrm{C}_{20} \mathrm{H}_{37} \mathrm{NO}_{5} \mathrm{Na}^{+}[\mathrm{M}+\mathrm{Na}]^{+}$394.2569, found 394.2569.

(S)-4-amino-5-oxoundecanoic acid ( $\mathrm{L}-15 \mathrm{~b})$ :<smiles></smiles>

To a solution of OtBu- $N$-Boc-protected L-glutamate hexyl ketone (S9, $27.8 \mathrm{mg}$, $0.075 \mathrm{mmol}, 1.0$ equiv) dissolved in DCM (3 mL) was added TFA (3 mL) at rt. After stirring for $3 \mathrm{~h}$, the reaction was concentrated by rotary evaporation. The residue was twice taken up in DCM and concentrated to remove TFA to afford $18.7 \mathrm{mg}$ of the title compound as a TFA salt with minor impurities $(75.8 \%$ yield) as an oil.

L-15b: $[\alpha]_{\mathrm{D}}^{28}+27.7(c 0.0011 \mathrm{~g} / \mathrm{mL}, \mathrm{MeOH})$; HRMS (ESI) $\mathrm{m} / z$ calculated for $\mathrm{C}_{11} \mathrm{H}_{20} \mathrm{NO}_{3}{ }^{-}[\mathrm{M}-\mathrm{H}]^{-}$214.1443, found 214.1440. ${ }^{1} \mathrm{H}$ NMR and ${ }^{13} \mathrm{C}$ NMR data have been showed in 1.3.

OtBu-N-Boc-protected L-glutamate heptyl ketone (S10):

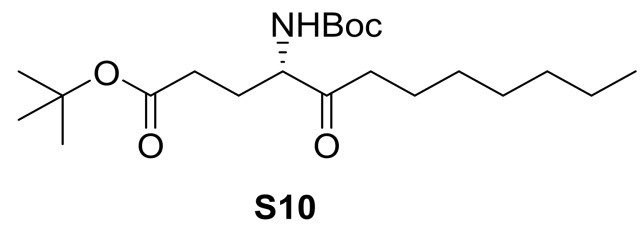

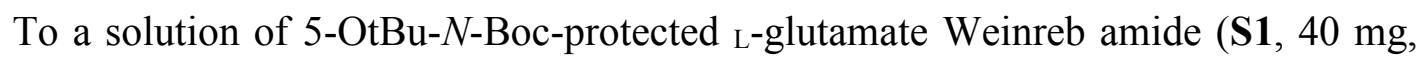
$0.116 \mathrm{mmol}, 1.0$ equiv) dissolved in THF $(3.3 \mathrm{~mL})$ was added a $1 \mathrm{M}$ solution of 
heptyl magnesium bromide in THF $\left(1.8 \mathrm{~mL}, 1.8 \mathrm{mmol}, 15.5\right.$ equiv) at $-20{ }^{\circ} \mathrm{C}$. After stirring for $24 \mathrm{~h}$ at the same temperature, the reaction was poured into $5 \mathrm{~mL}$ of saturated $\mathrm{NH}_{4} \mathrm{Cl}$. The aqueous phase was extracted with EtOAc $(3 \mathrm{x})$. The organic layers were combined, washed with brine, dried over $\mathrm{Na}_{2} \mathrm{SO}_{4}$, filtered, and evaporated under reduced pressure to afford an oil. The crude residue was purified by preparative TLC (10:1 hexanes/EtOAc v/v) to afford $4.6 \mathrm{mg}$ of the title compound (10.3\% yield) as an oil.

S10: $\mathrm{R}_{f}=0.3(10: 1$ hexanes/EtOAc $\mathrm{v} / \mathrm{v})$; HRMS (ESI) $m / z$ calculated for $\mathrm{C}_{21} \mathrm{H}_{39} \mathrm{NO}_{5} \mathrm{Na}^{+}[\mathrm{M}+\mathrm{Na}]^{+}$408.2726, found 408.2735.

\section{(S)-4-amino-5-oxododecanoic acid (L-16b):}

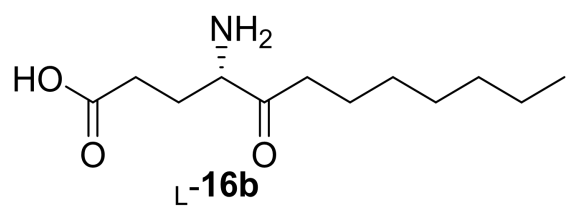

To a solution of OtBu- $N$-Boc-protected L-glutamate heptyl ketone (S10, $4.6 \mathrm{mg}$, 0.012 mmol, 1.0 equiv) dissolved in DCM $(1 \mathrm{~mL})$ was added TFA $(1 \mathrm{~mL})$ at rt. After stirring for $3 \mathrm{~h}$, the reaction was concentrated by rotary evaporation. The residue was twice taken up in DCM and concentrated to remove TFA to afford $3.1 \mathrm{mg}$ of the title compound as a TFA salt with minor impurities $(75.3 \%$ yield) as an oil.

L-16b: HRMS (ESI) $\mathrm{m} / \mathrm{z}$ calculated for $\mathrm{C}_{12} \mathrm{H}_{22} \mathrm{NO}_{3}^{-}[\mathrm{M}-\mathrm{H}]^{-}$228.1600, found 228.1596. ${ }^{1} \mathrm{H}$ NMR and ${ }^{13} \mathrm{C}$ NMR data have been showed in $\mathbf{1 . 3}$.

Besides, we also tried to synthesize the other five $\alpha$-amino ketone standards $(\mathrm{L}-\mathbf{3 b}$, ${ }_{L}-\mathbf{4 b}, L_{L}-\mathbf{5 b}, L_{L}-\mathbf{6 b}$ and $\left.{ }_{L}-\mathbf{8 b}\right)$ under the same condition, but we didn't observe the products. Probably because the yield of ${ }_{\mathrm{L}} \mathbf{- 3 \mathbf { b }}$ was too low to get the product. The corresponding Grignard reagent substrates for synthesizing $\mathrm{L}_{\mathbf{-}} \mathbf{4 b}$ and $\mathrm{L}_{\mathrm{-}} \mathbf{- 8 b}$ were not commercially available. In the deprotection step using TFA in the synthesis of ${ }_{L}-5 \mathbf{b}$ and $\mathrm{L}_{\mathrm{-}} \mathbf{- 6} \mathbf{b}$, the two $\alpha$-amino ketones seemed to be unstable. 


\section{$1.3{ }^{1} \mathrm{H}$ NMR and ${ }^{13} \mathrm{C}$ NMR spectra of compounds.}

The ${ }^{1} \mathrm{H}(600 \mathrm{MHz})$ and ${ }^{13} \mathrm{C}$ NMR (150 MHz) spectra of compounds, $\mathrm{L}-\mathbf{2} \mathbf{b}, \mathrm{D}_{\mathbf{2}} \mathbf{- 2} \mathbf{b}$, $\mathrm{L}-\mathbf{7 b},{ }_{\mathrm{L}}-\mathbf{1 2 b}, \mathrm{L}_{\mathrm{L}} \mathbf{- 1 3 b},{ }_{\mathrm{L}}-\mathbf{1 4 b},{ }_{\mathrm{L}}-\mathbf{1 5 b}$, and $\mathrm{L}_{\mathrm{L}}-\mathbf{1 6 b}$ were recorded in DMSO- $d_{6}$.

\subsection{1 (S)-4-amino-7-methyl-5-oxooct-6-enoic acid (L-2b)}

\begin{tabular}{|c|c|c|c|}
\hline \multirow[b]{2}{*}{$\begin{array}{l}\text { No. } \\
\text { position }\end{array}$} & \multicolumn{3}{|c|}{ 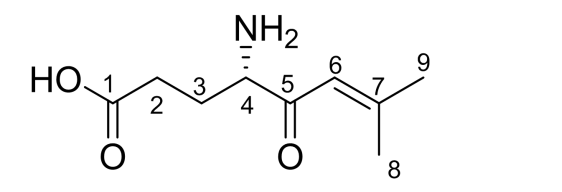 } \\
\hline & \multicolumn{3}{|c|}{$\begin{array}{l}{ }_{\mathrm{L}}{ }^{-2 \mathbf{b}} \\
\delta_{\mathrm{H}}, \text { multi }(J \text { in } \mathrm{Hz})\end{array}$} \\
\hline 1 & $173.4, \mathrm{C}$ & & \\
\hline 2 & $29.1, \mathrm{CH}_{2}$ & $2.41, \mathrm{~m}$ & $2.27, \mathrm{~m}$ \\
\hline 3 & 25.3, $\mathrm{CH}_{2}$ & $2.04, \mathrm{~m}$ & $1.85, \mathrm{~m}$ \\
\hline 4 & $57.5, \mathrm{CH}$ & $4.10, \mathrm{~m}$ & \\
\hline 5 & 194.7, C & & \\
\hline 6 & $120.1, \mathrm{CH}$ & $6.30, \mathrm{~s}$ & \\
\hline 7 & 161.1, C & & \\
\hline 8 & $21.1, \mathrm{CH}_{3}$ & $2.14, \mathrm{~s}$ & \\
\hline 9 & $27.7, \mathrm{CH}_{3}$ & $1.94, \mathrm{~s}$ & \\
\hline 10 & $\mathrm{NH}^{+}$ & $8.19, \mathrm{~s}$ & \\
\hline
\end{tabular}

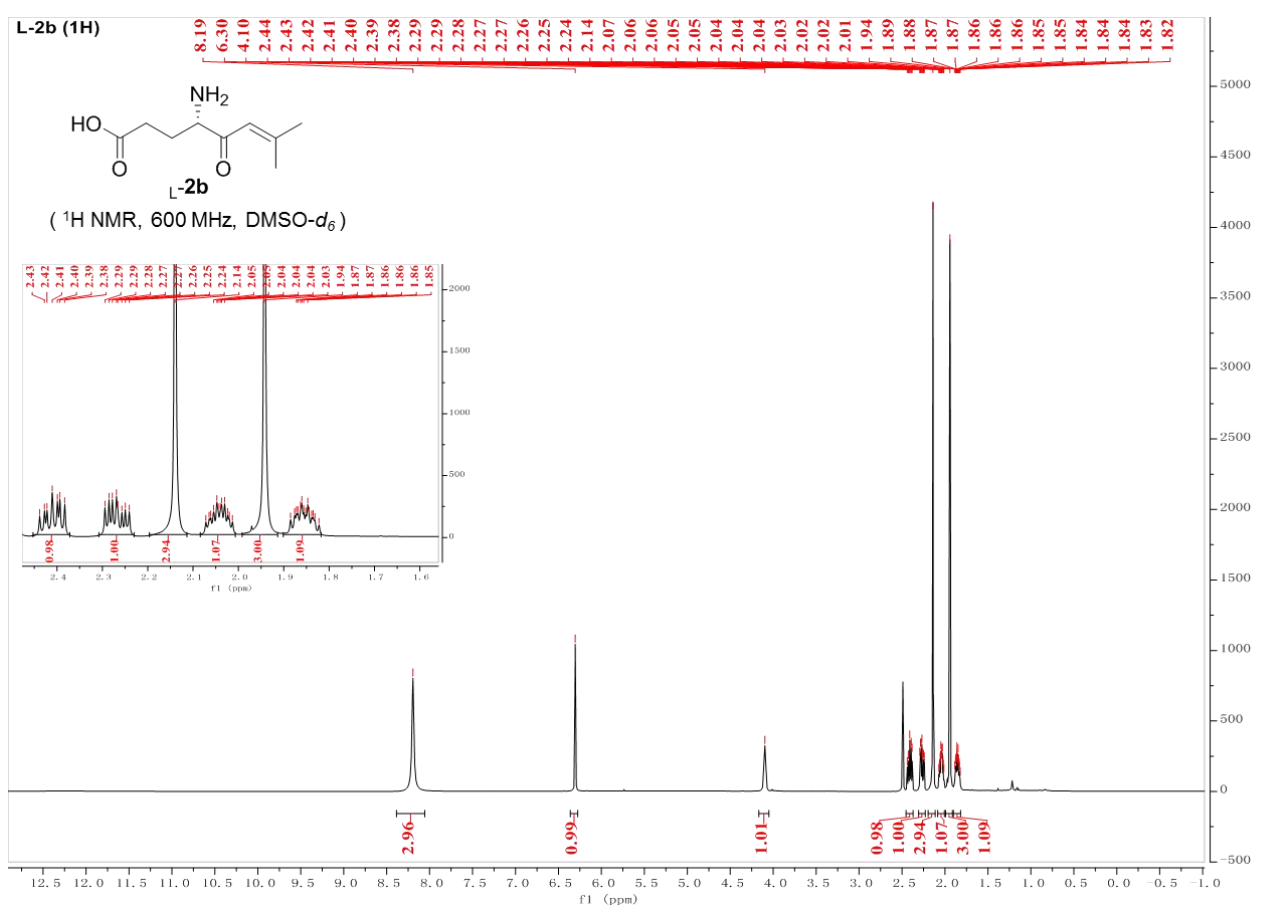



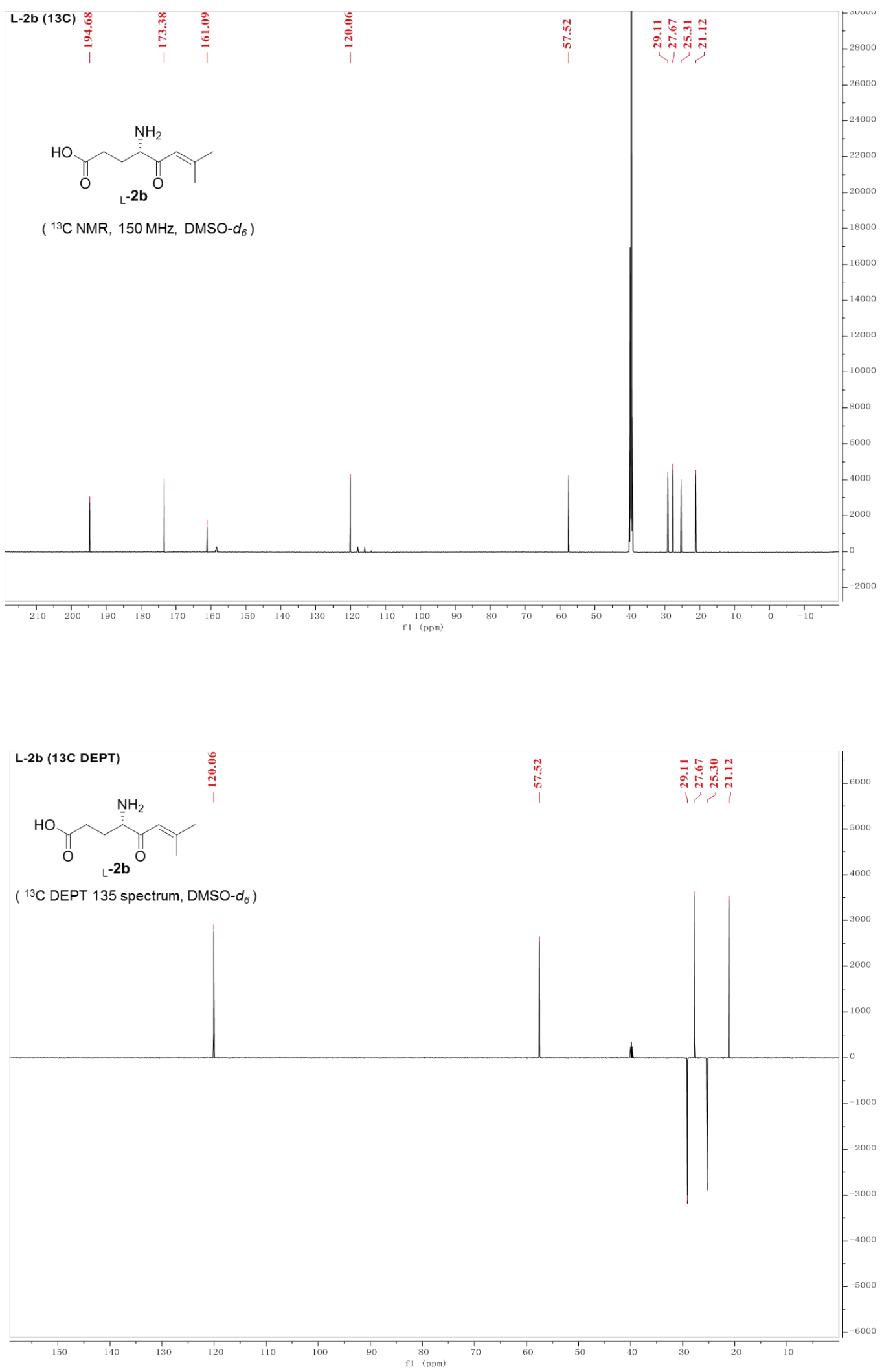

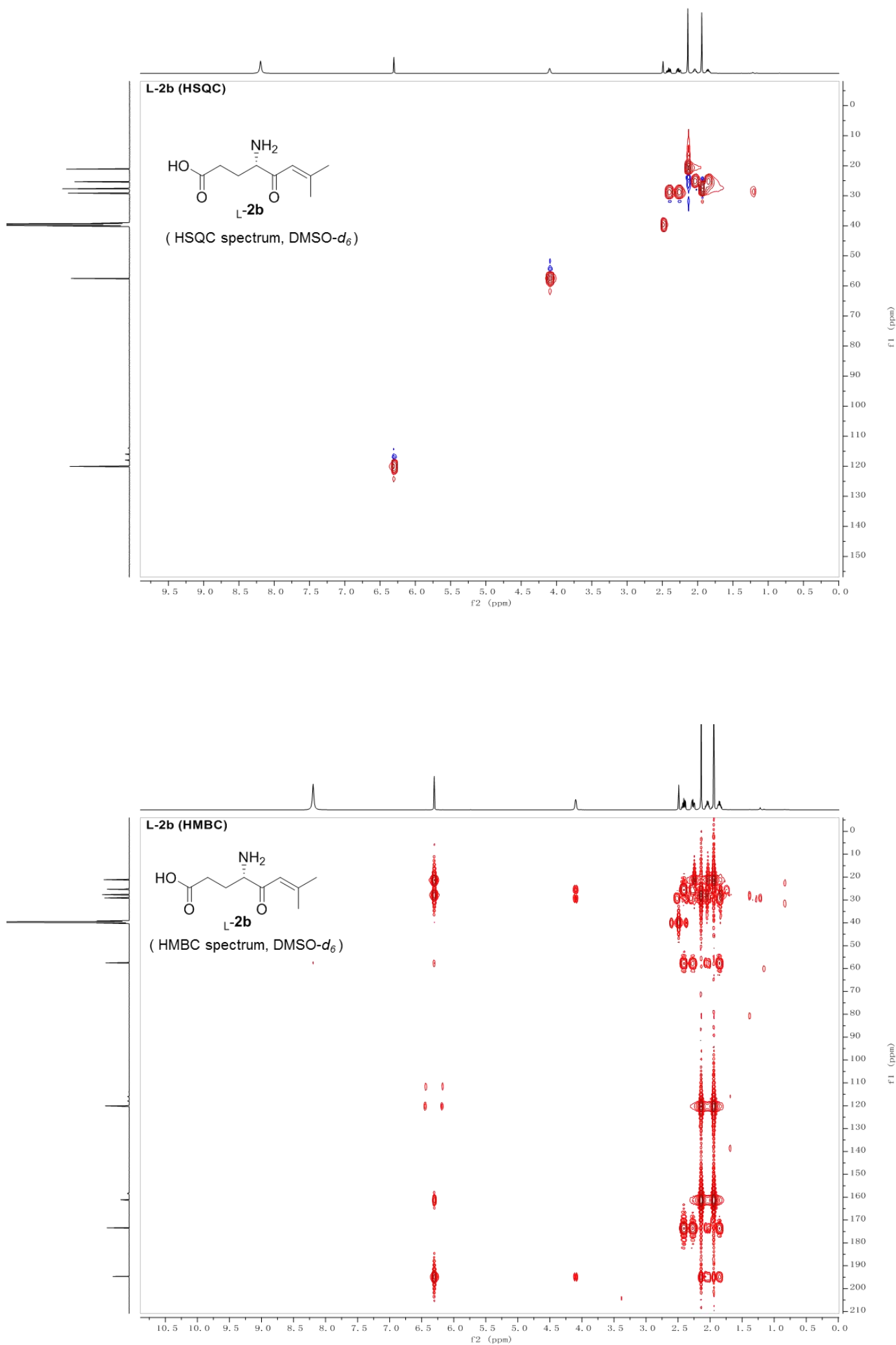


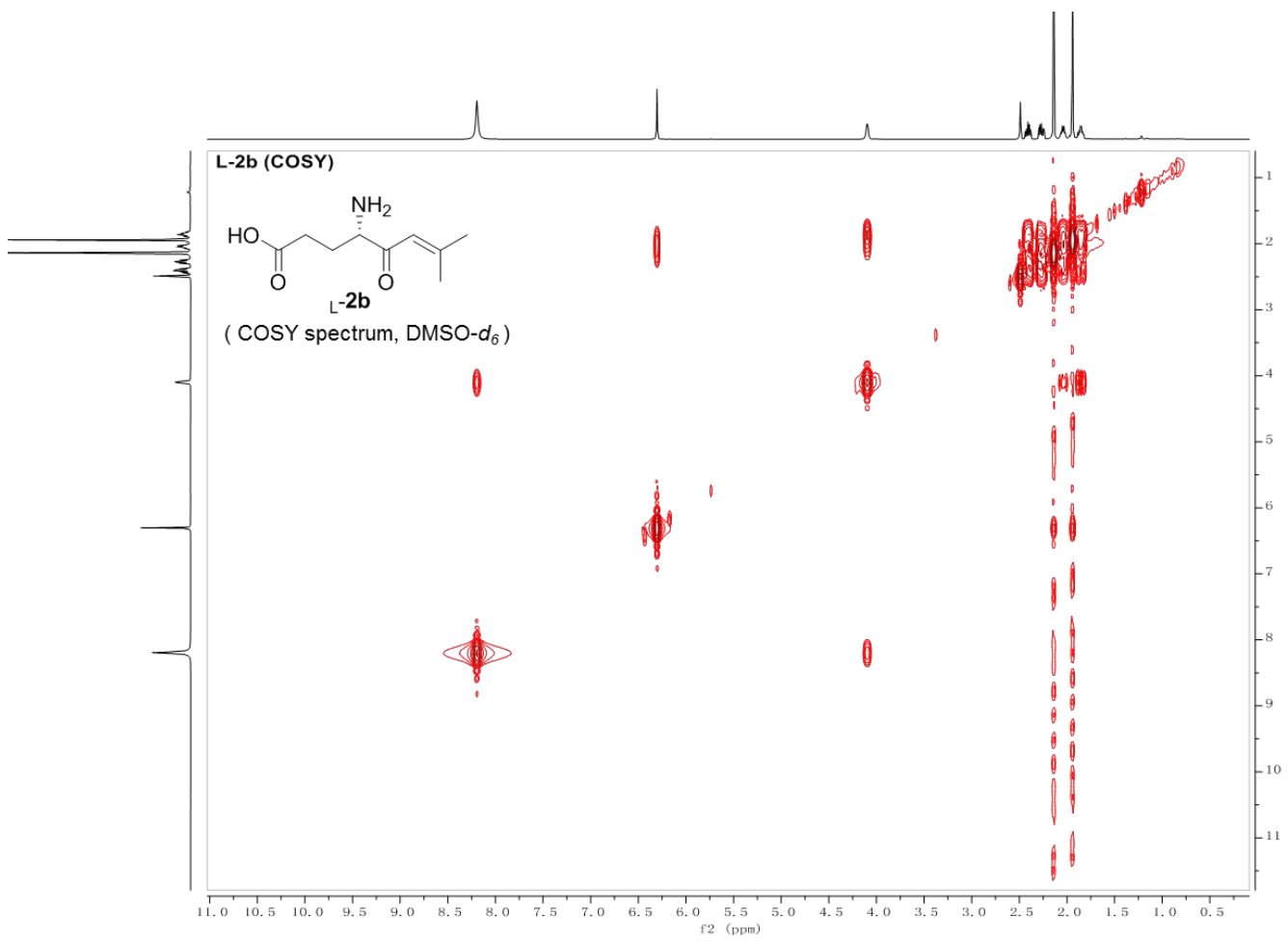

1.3.2 (R)-4-amino-7-methyl-5-oxooct-6-enoic acid (D-2b)<smiles>CC(C)=CC(=O)[C@H](N)CCC(=O)O</smiles>

\begin{tabular}{llll}
\hline $\begin{array}{l}\text { No. } \\
\text { position }\end{array}$ & $\delta_{\mathrm{C}}$, type & $\begin{array}{l}\mathrm{D}^{-2 \mathbf{b}} \\
\delta_{\mathrm{H}}, \text { multi }(J \text { in } \mathrm{Hz})\end{array}$ \\
\hline 1 & $173.4, \mathrm{C}$ & & \\
2 & $29.1, \mathrm{CH}_{2}$ & $2.41, \mathrm{~m}$ & $2.27, \mathrm{~m}$ \\
3 & $25.3, \mathrm{CH}_{2}$ & $2.04, \mathrm{~m}$ & $1.86, \mathrm{~m}$ \\
4 & $57.5, \mathrm{CH}$ & $4.10, \mathrm{~m}$ & \\
5 & $194.7, \mathrm{C}$ & & \\
6 & $120.1, \mathrm{CH}$ & $6.31, \mathrm{~s}$ & \\
7 & $161.1, \mathrm{C}$ & & \\
8 & $21.1, \mathrm{CH}_{3}$ & $2.14, \mathrm{~s}$ & \\
9 & $27.7, \mathrm{CH}_{3}$ & $1.94, \mathrm{~s}$ & \\
10 & $\mathrm{NH}^{+}$ & $8.19, \mathrm{~s}$ & \\
\hline
\end{tabular}



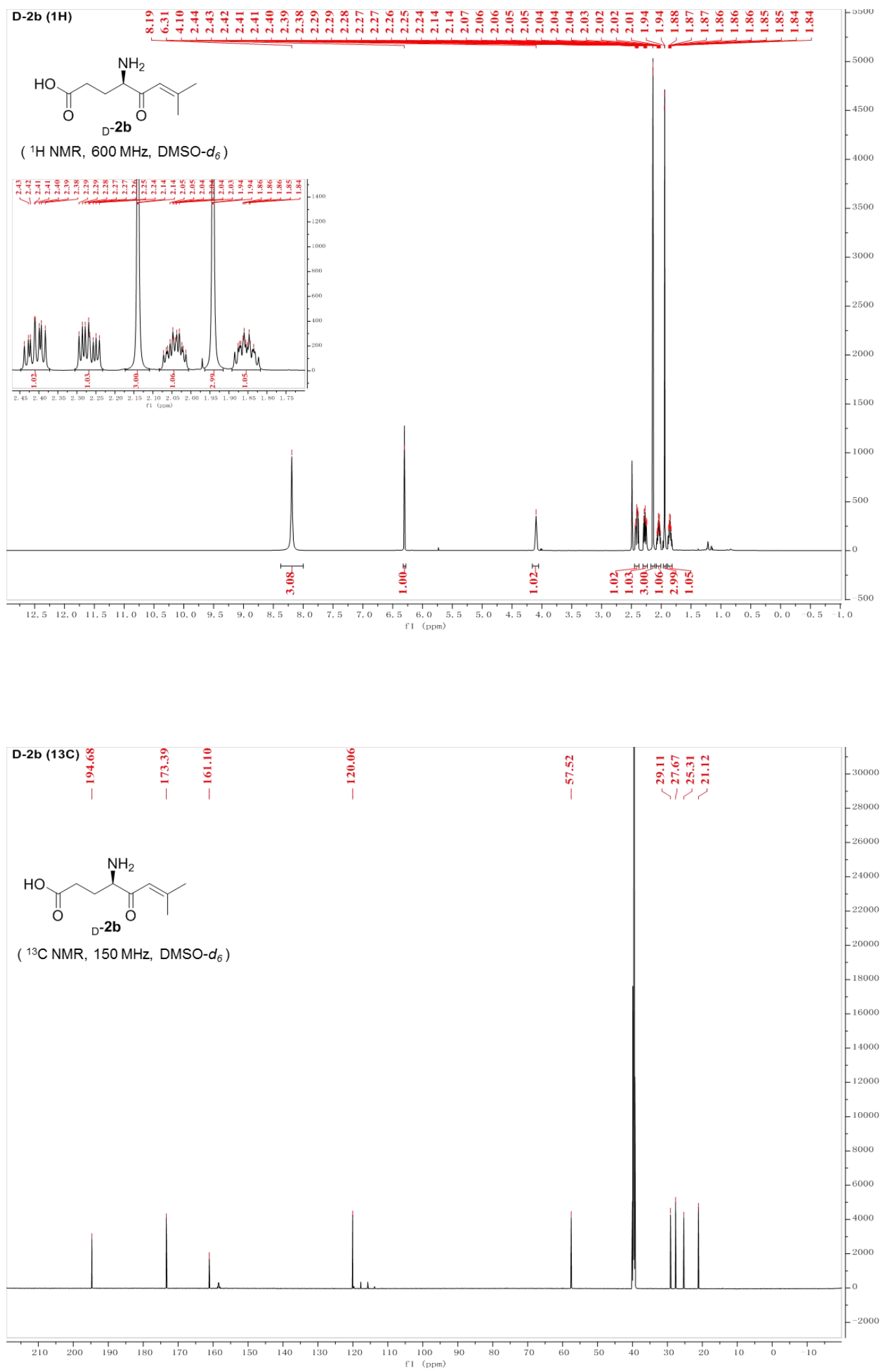

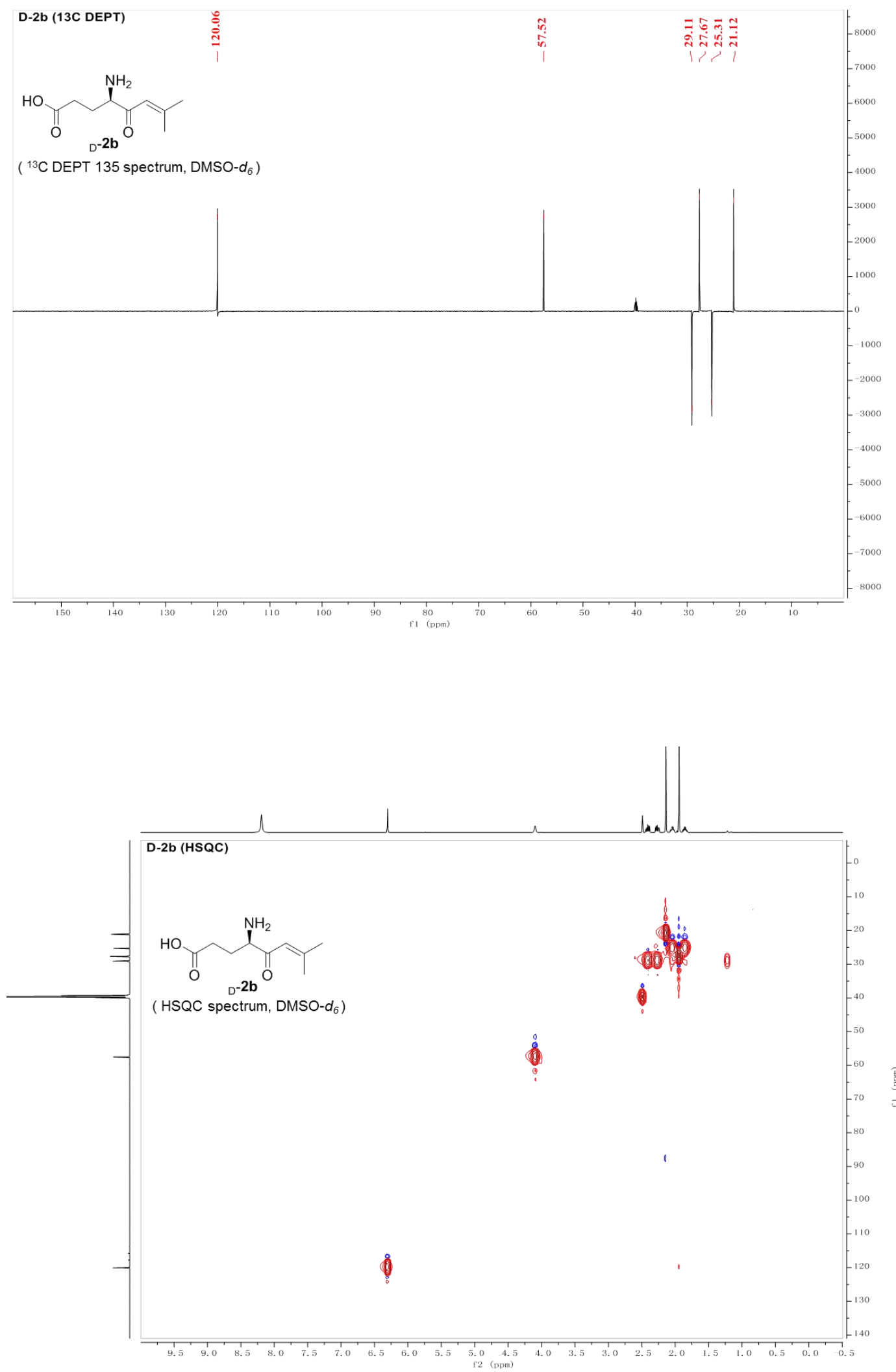

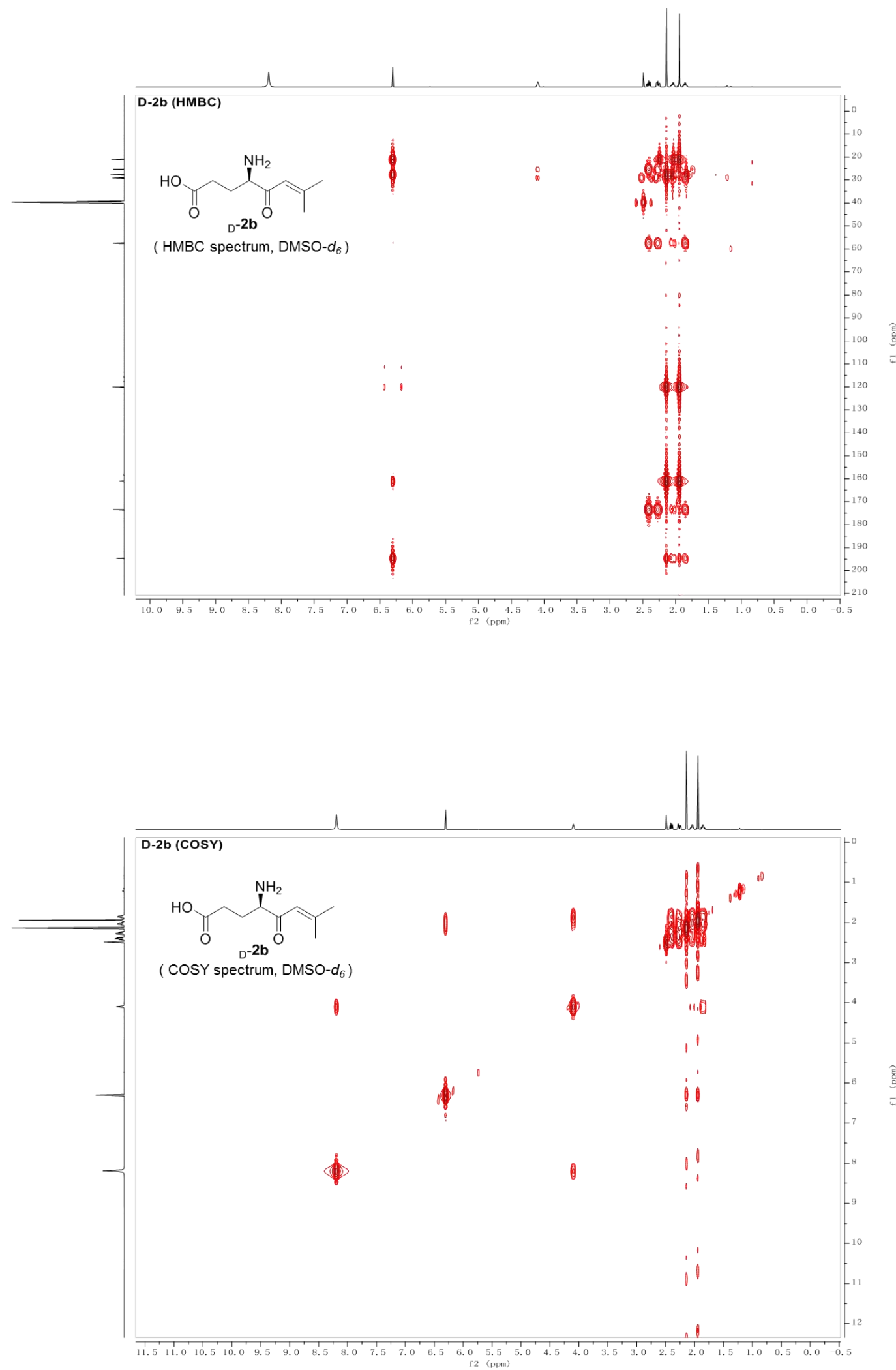


\subsection{3 (S)-4-amino-5-oxonon-8-enoic acid ( $\mathrm{L}-7 \mathrm{~b})$}

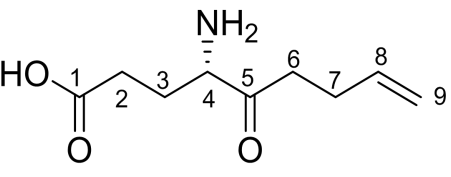

\begin{tabular}{llll}
\hline $\begin{array}{l}\text { No. } \\
\text { position }\end{array}$ & $\delta_{\mathrm{C}}$, type & \multicolumn{2}{c}{${ }^{-7 \mathbf{b}}$} \\
\hline 1 & $173.4, \mathrm{C}$ & & \\
2 & $28.9, \mathrm{CH}_{2}$ & $2.41, \mathrm{~m}$ & $2.31, \mathrm{~m}$ \\
3 & $24.5, \mathrm{CH}_{2}$ & $2.12, \mathrm{~m}$ & $1.89, \mathrm{~m}$ \\
4 & $57.3, \mathrm{CH}$ & $4.17, \mathrm{~m}$ & \\
5 & $205.7, \mathrm{C}$ & & \\
6 & $37.6, \mathrm{CH}_{2}$ & $2.79, \mathrm{~m}$ & $2.66, \mathrm{~m}$ \\
7 & $26.8, \mathrm{CH}_{2}$ & $2.25, \mathrm{~m}$ & \\
8 & $137.1, \mathrm{CH}$ & $5.79, \mathrm{~m}$ & \\
9 & $115.6, \mathrm{CH}_{2}$ & $5.05, \mathrm{~m}$ & $4.98, \mathrm{~m}$ \\
\hline
\end{tabular}

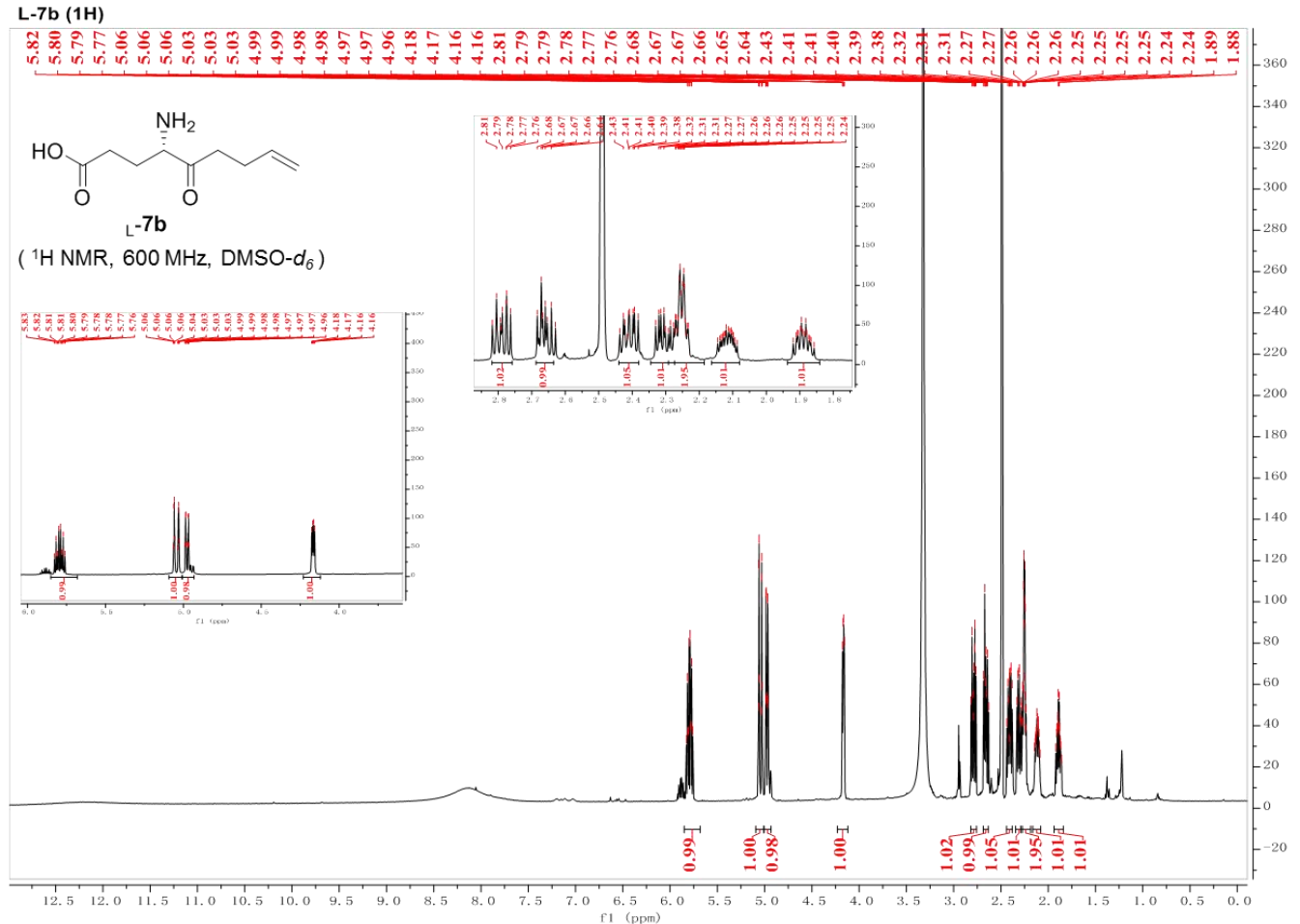



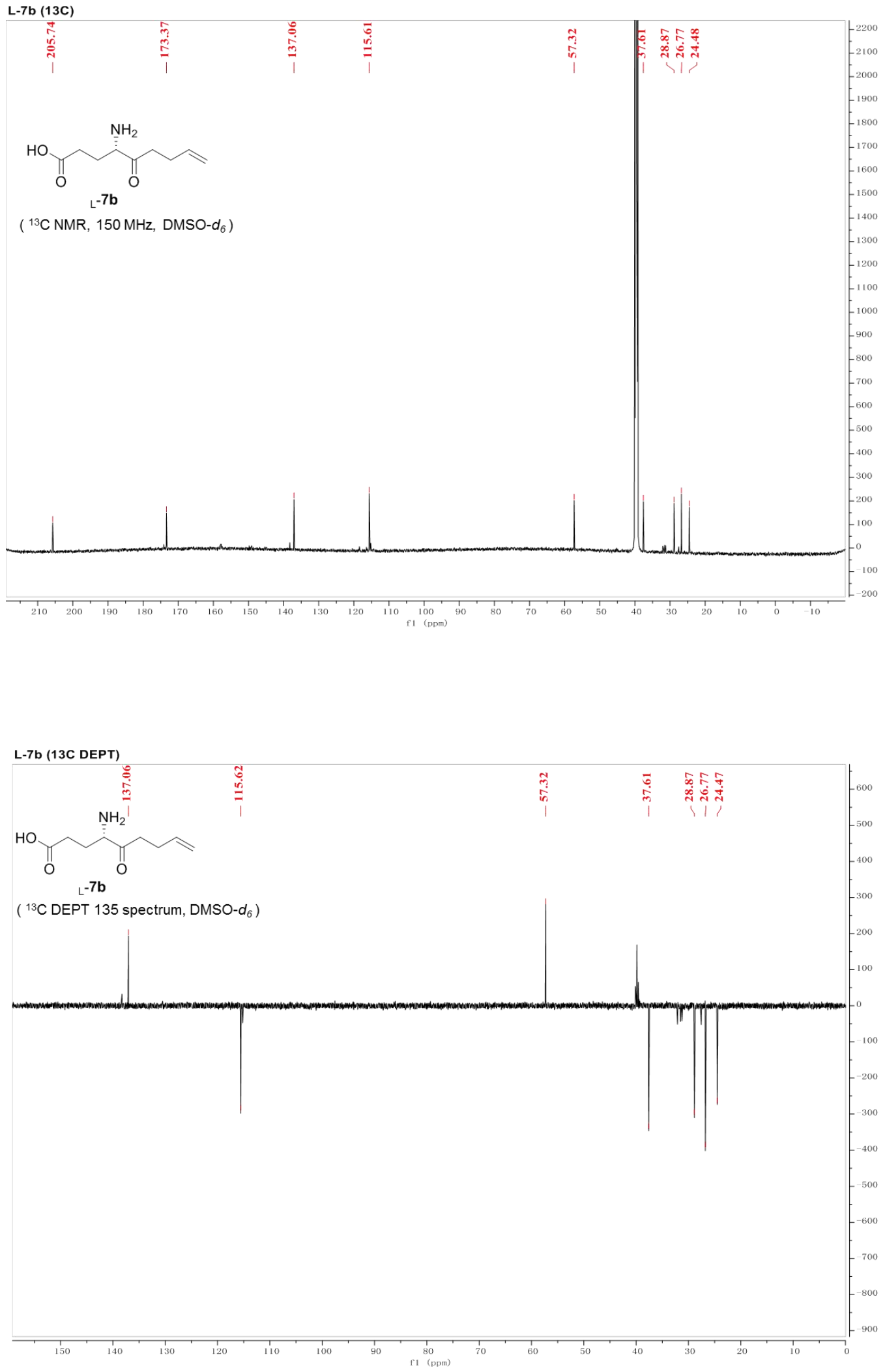

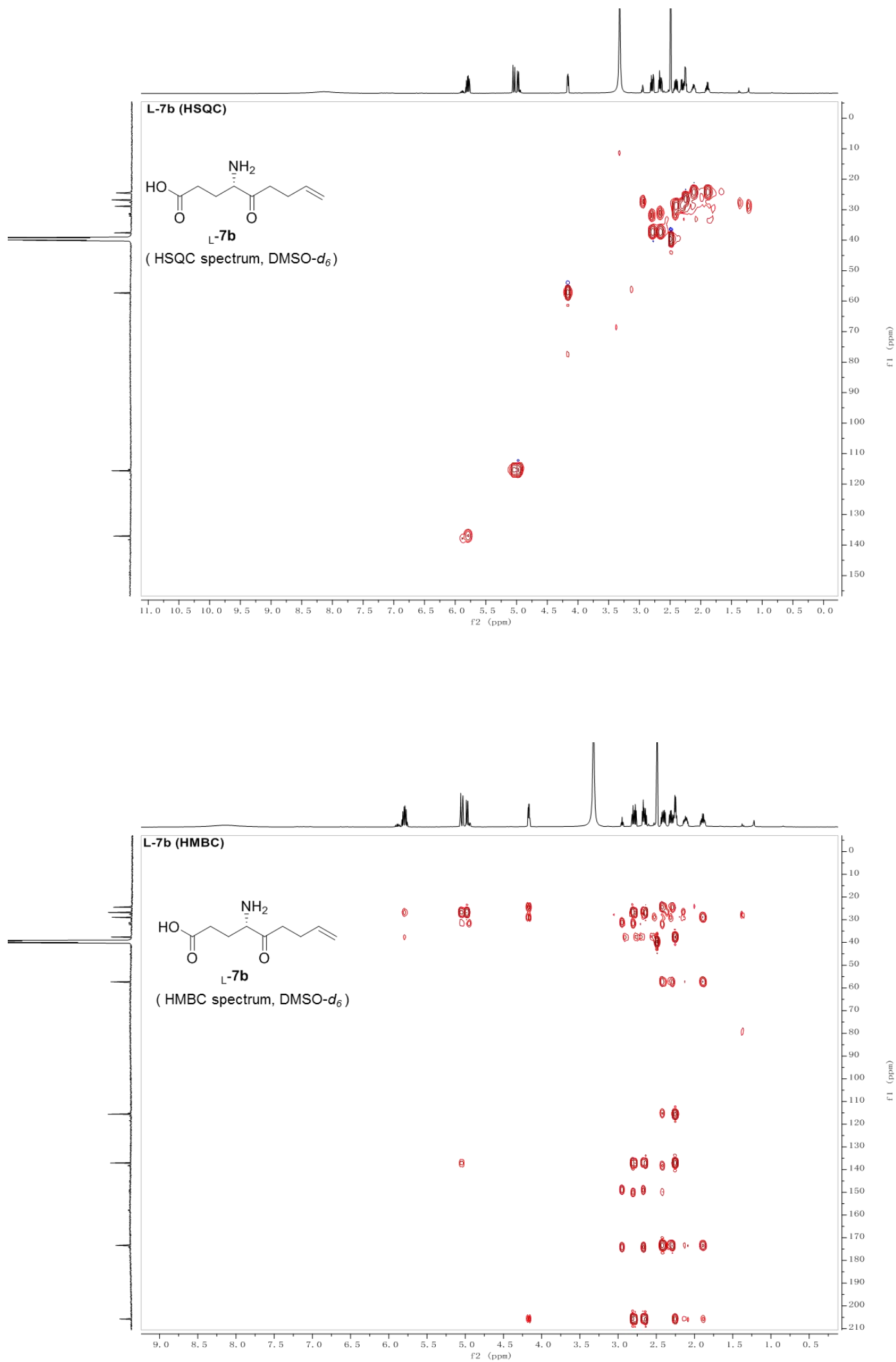


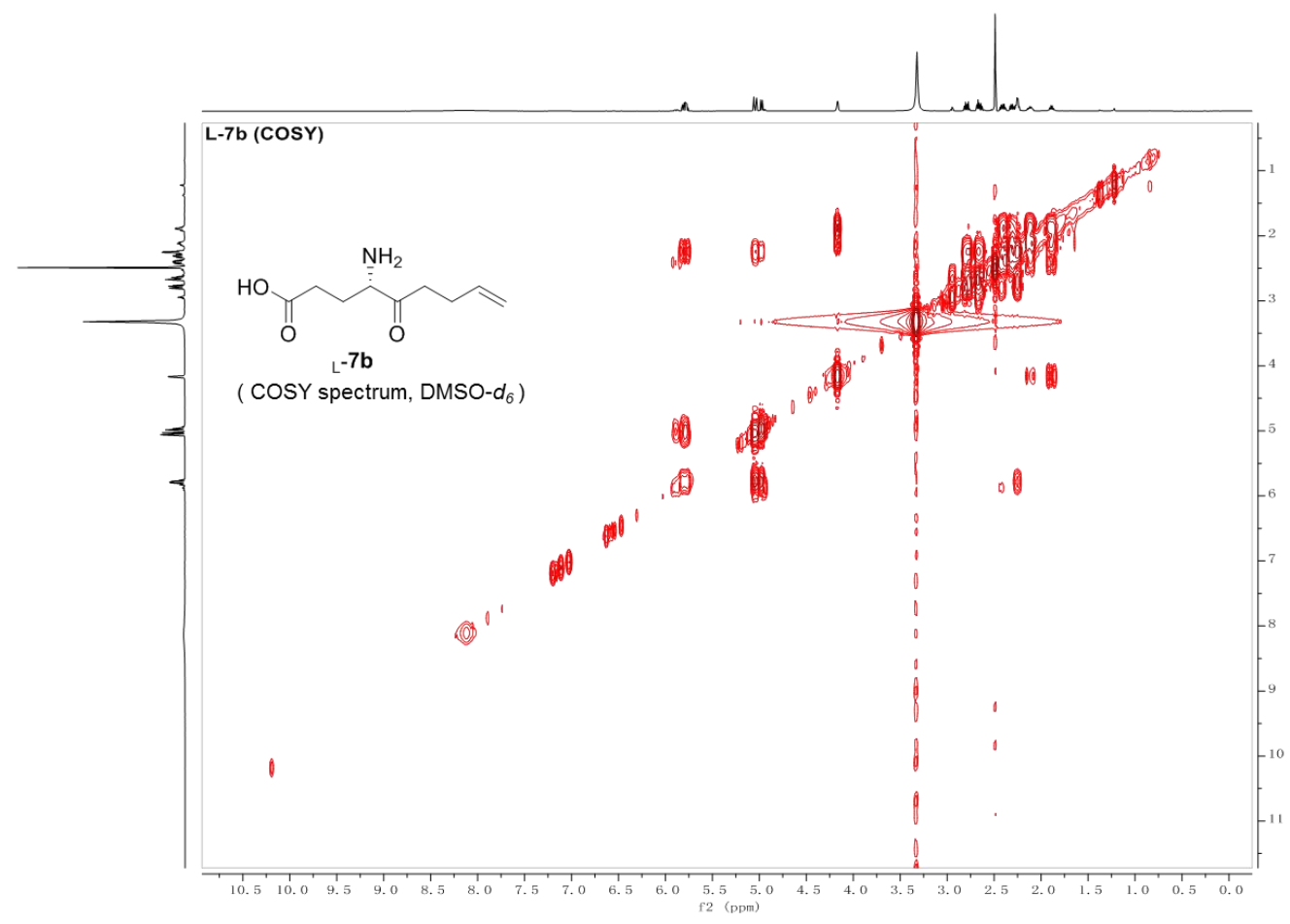

1.3.4 (S) -4-amino-5-oxooctanoic acid (L-12b)

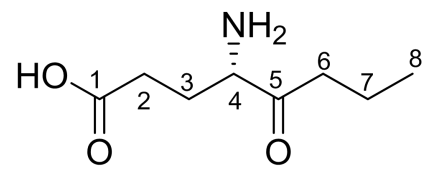

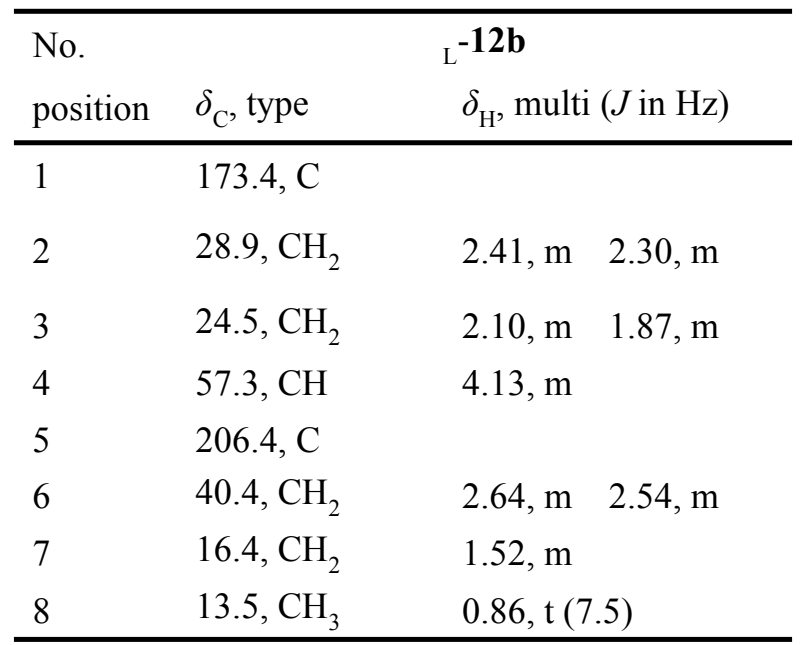



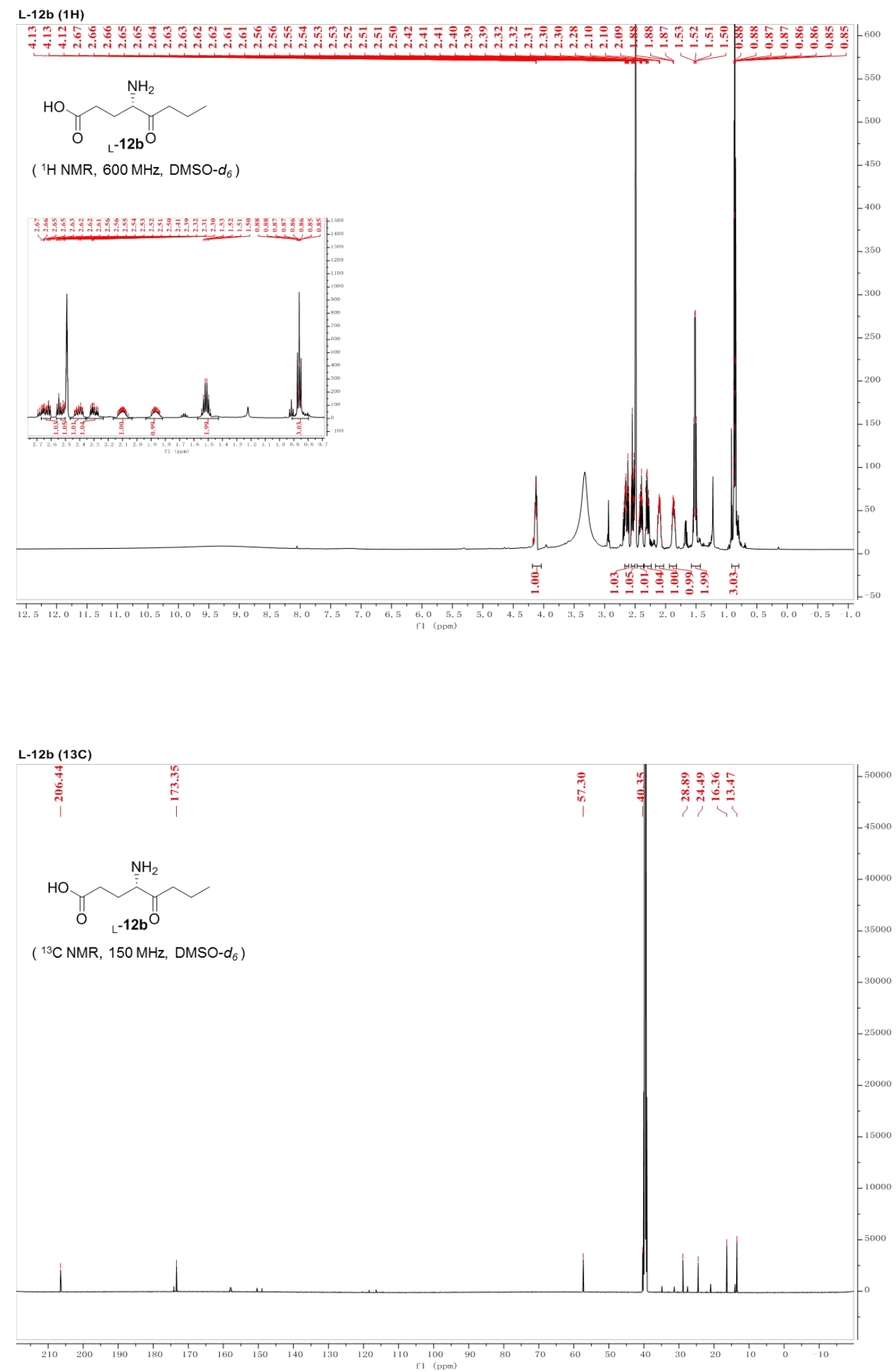

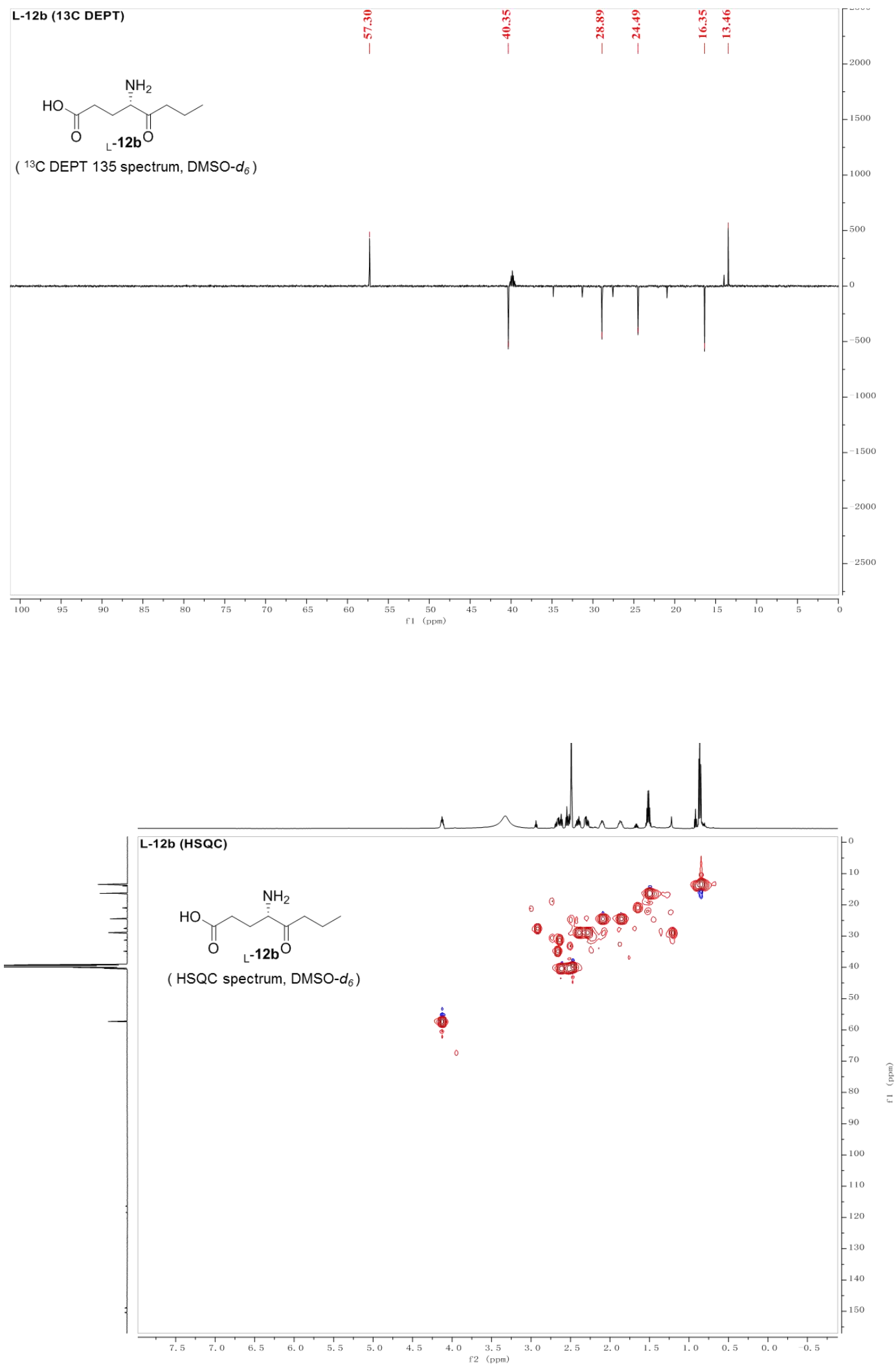

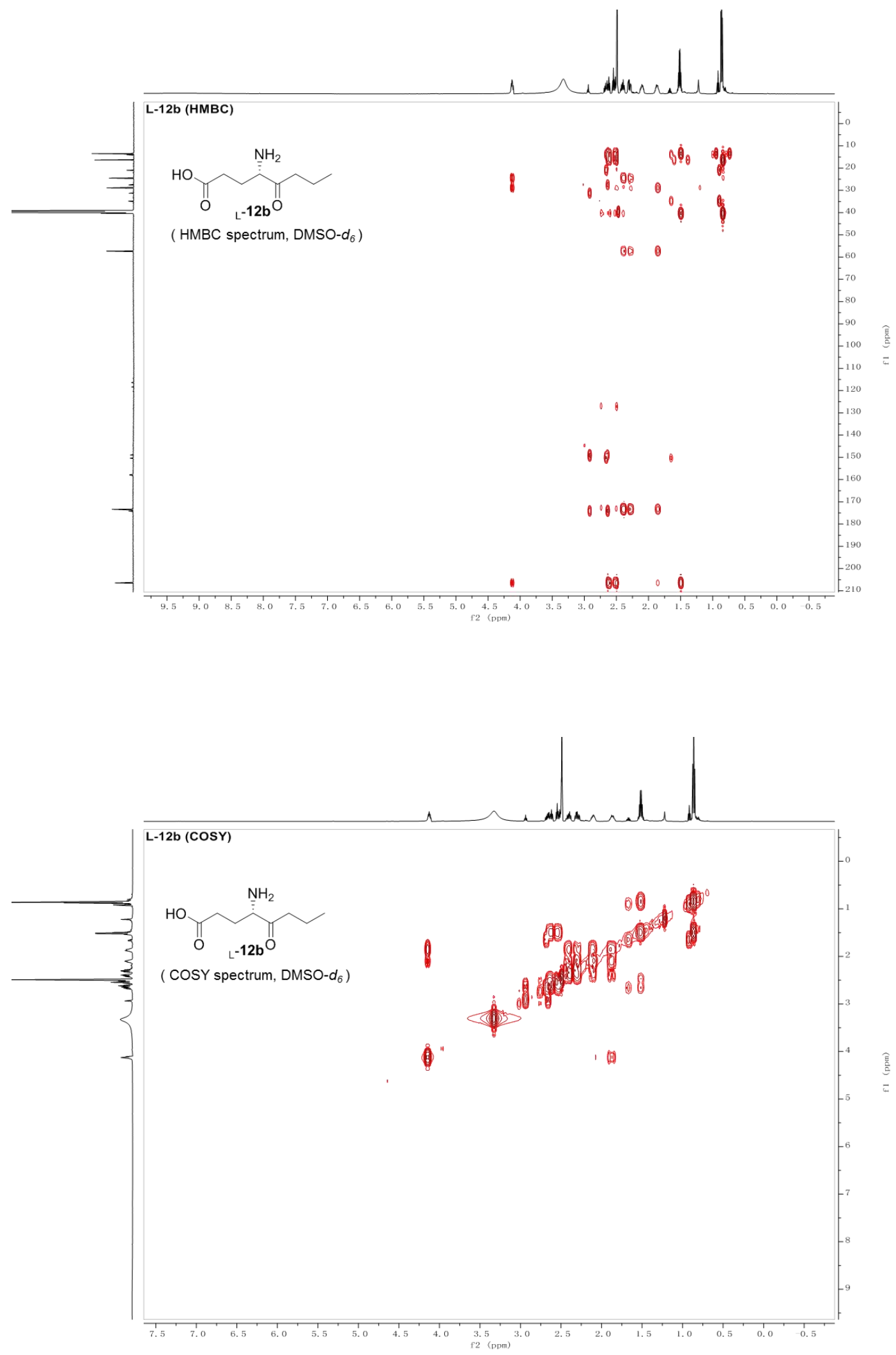
1.3.5 (S)-4-amino-5-oxononanoic acid ( $\mathrm{L}-13 \mathrm{~b})$<smiles>CCCCC(=O)[C@H](N)CCC(=O)O</smiles>

\begin{tabular}{|c|c|c|}
\hline $\begin{array}{l}\text { No. } \\
\text { position }\end{array}$ & $\delta_{\mathrm{C}}$, type & $\begin{array}{l}\mathrm{L}^{-\mathbf{1 3 b}} \\
\delta_{\mathrm{H}}, \text { multi }(J \text { in } \mathrm{Hz})\end{array}$ \\
\hline 1 & 173.2, C & \\
\hline 2 & 29.0, $\mathrm{CH}_{2}$ & $2.40, \mathrm{~m} \quad 2.30, \mathrm{~m}$ \\
\hline 3 & 24.6, $\mathrm{CH}_{2}$ & $2.10, \mathrm{~m} \quad 1.87, \mathrm{~m}$ \\
\hline 4 & $57.4, \mathrm{CH}$ & $4.11, \mathrm{~m}$ \\
\hline 5 & 206.8, C & \\
\hline 6 & $38.2, \mathrm{CH}_{2}$ & $2.65, \mathrm{~m} \quad 2.55, \mathrm{~m}$ \\
\hline 7 & $25.0, \mathrm{CH}_{2}$ & $1.47, \mathrm{~m}$ \\
\hline 8 & $21.6, \mathrm{CH}_{2}$ & $1.25, \mathrm{~m}$ \\
\hline 9 & $13.8, \mathrm{CH}_{3}$ & $0.86, \mathrm{t}(7.3)$ \\
\hline
\end{tabular}

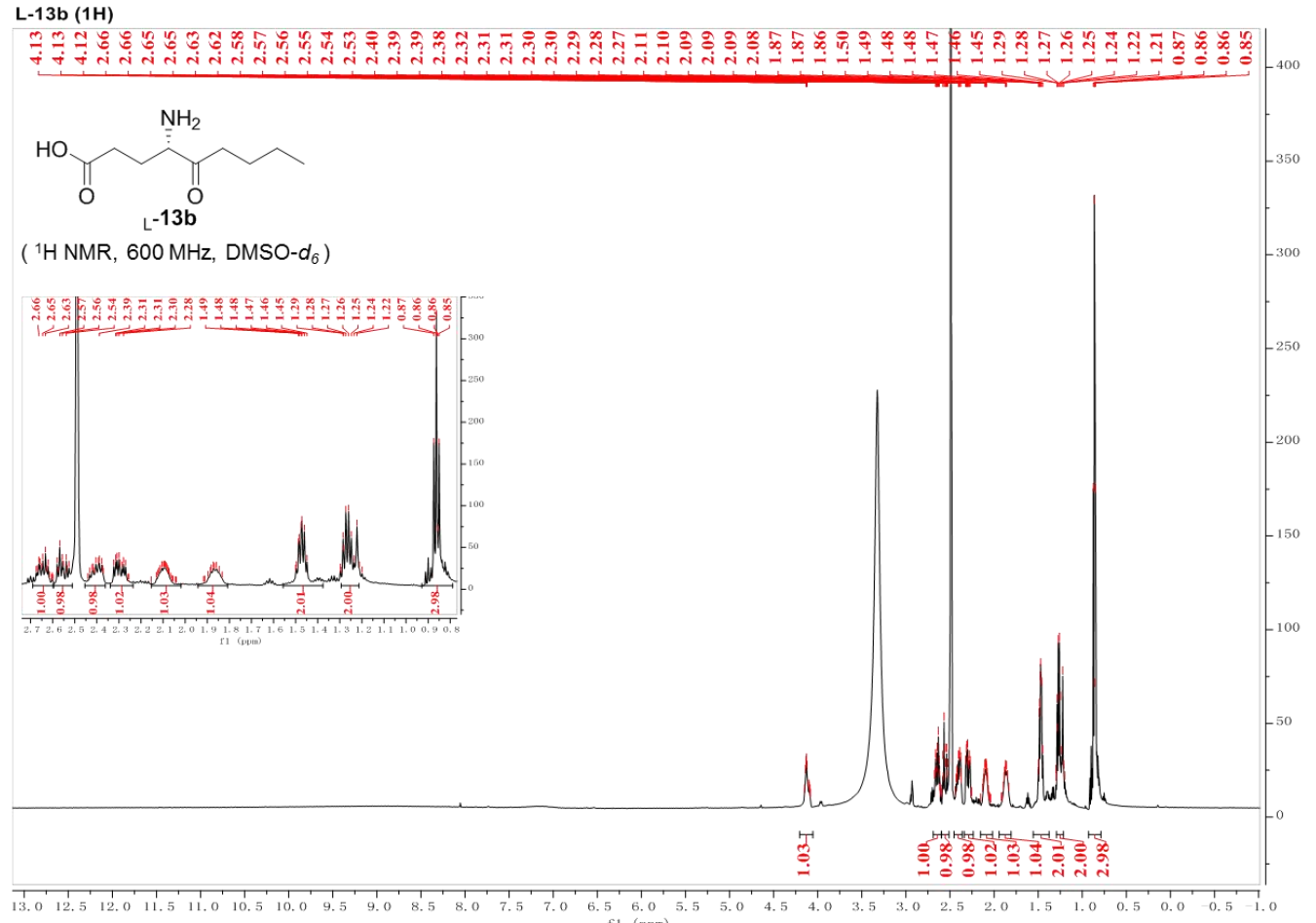



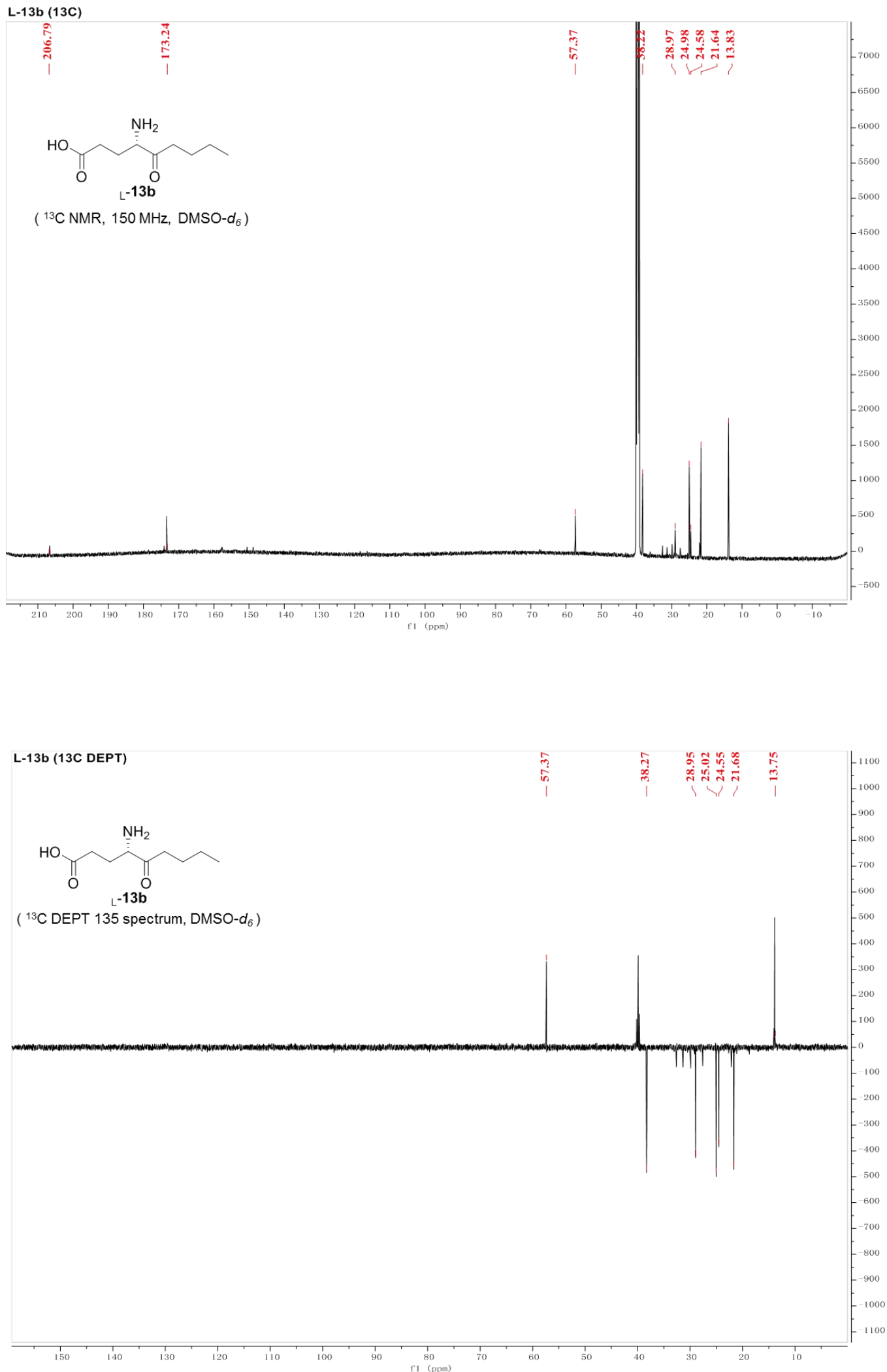

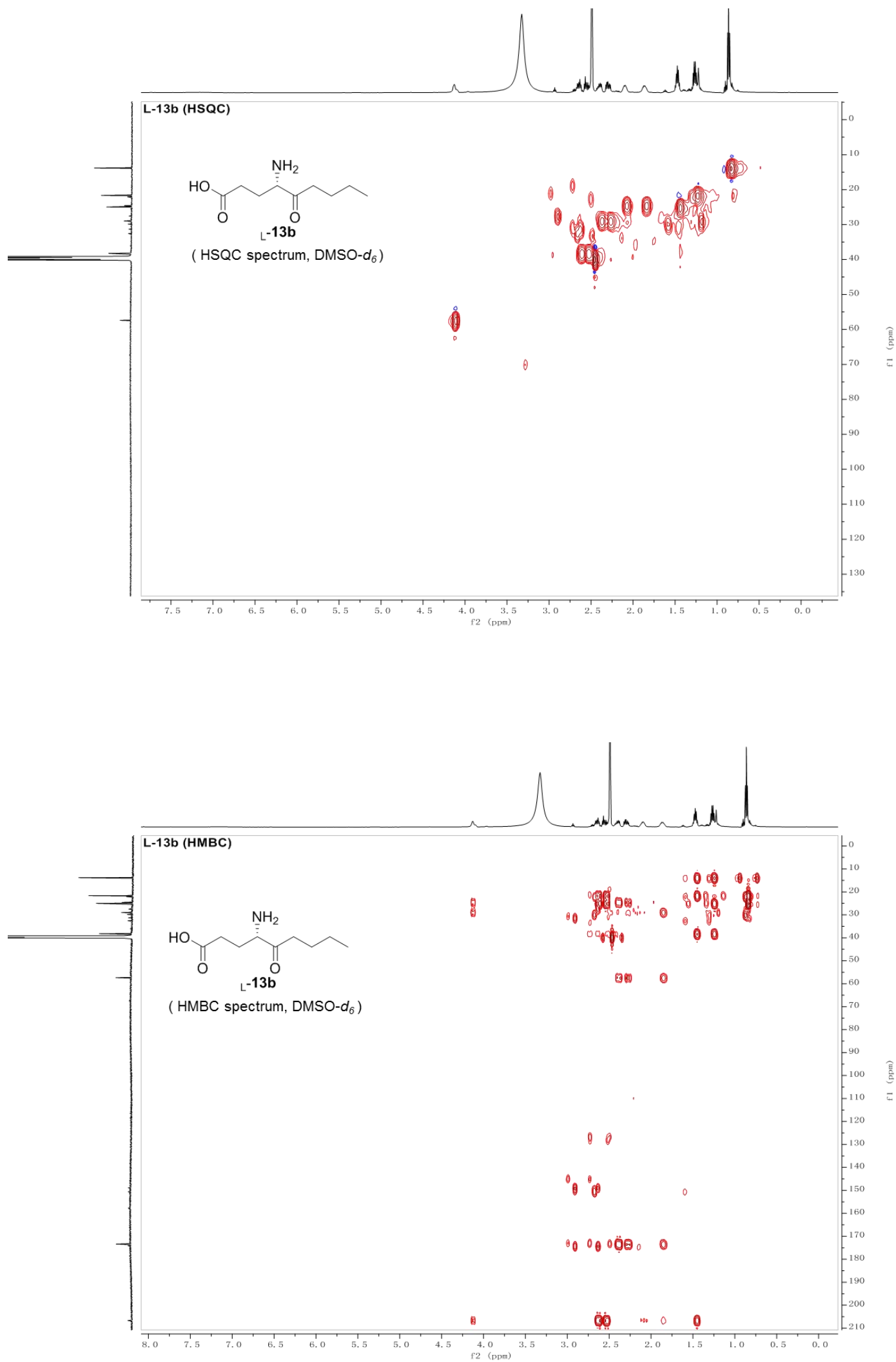


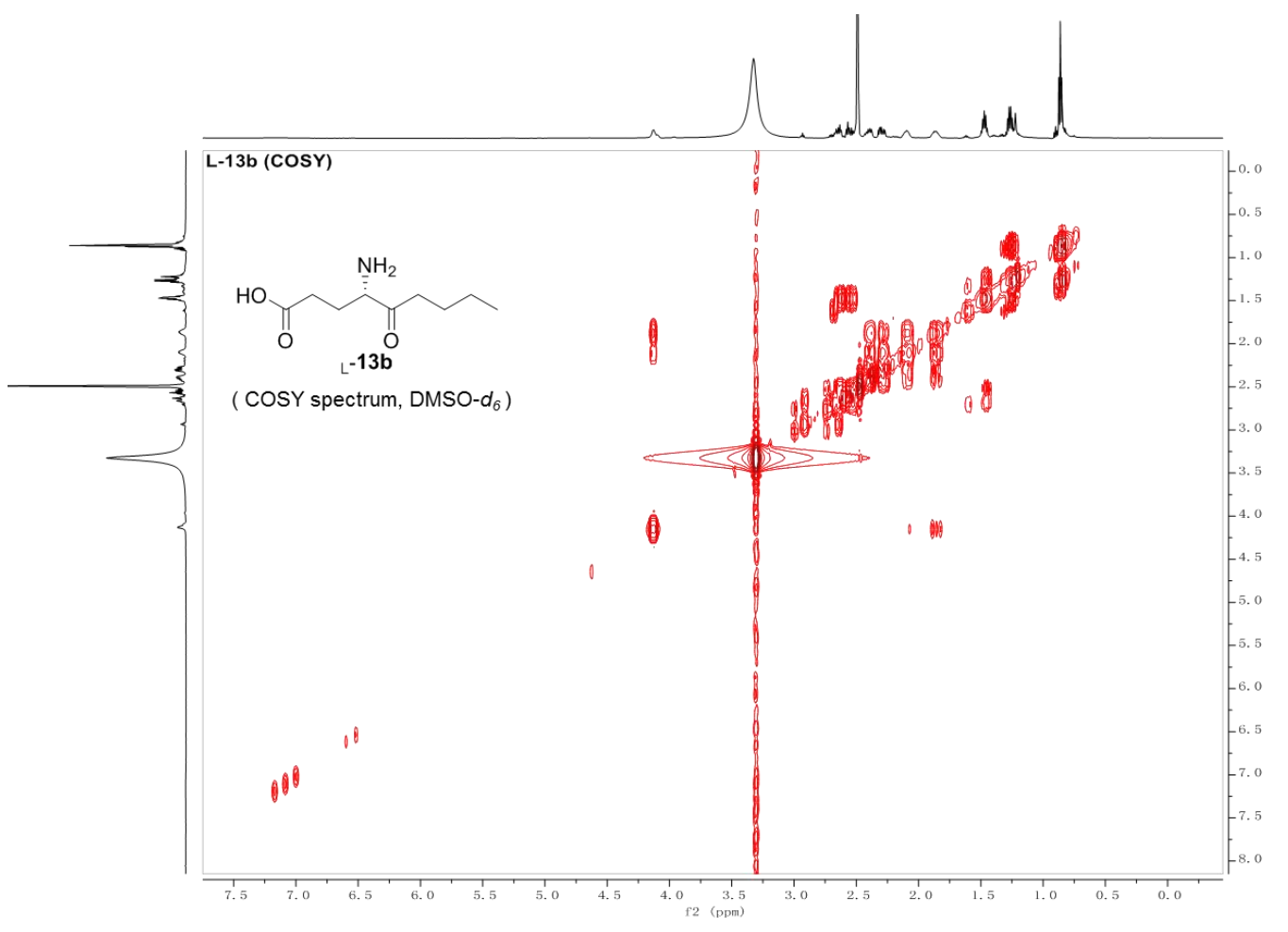

\subsection{6 (S)-4-amino-5-oxodecanoic acid (L-14b)}

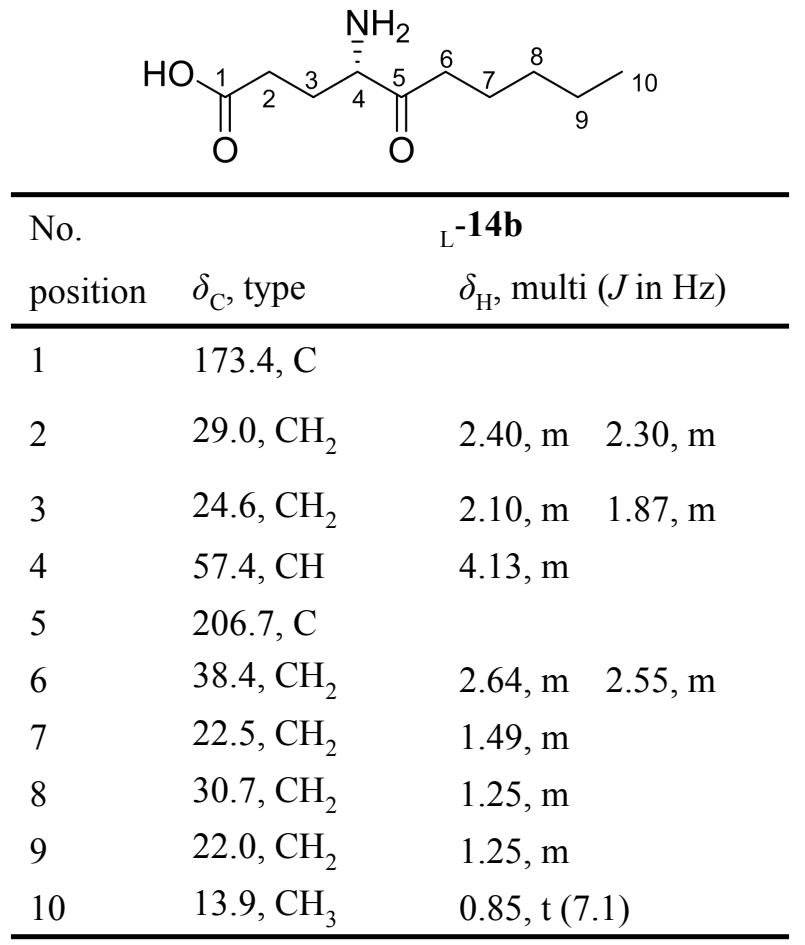



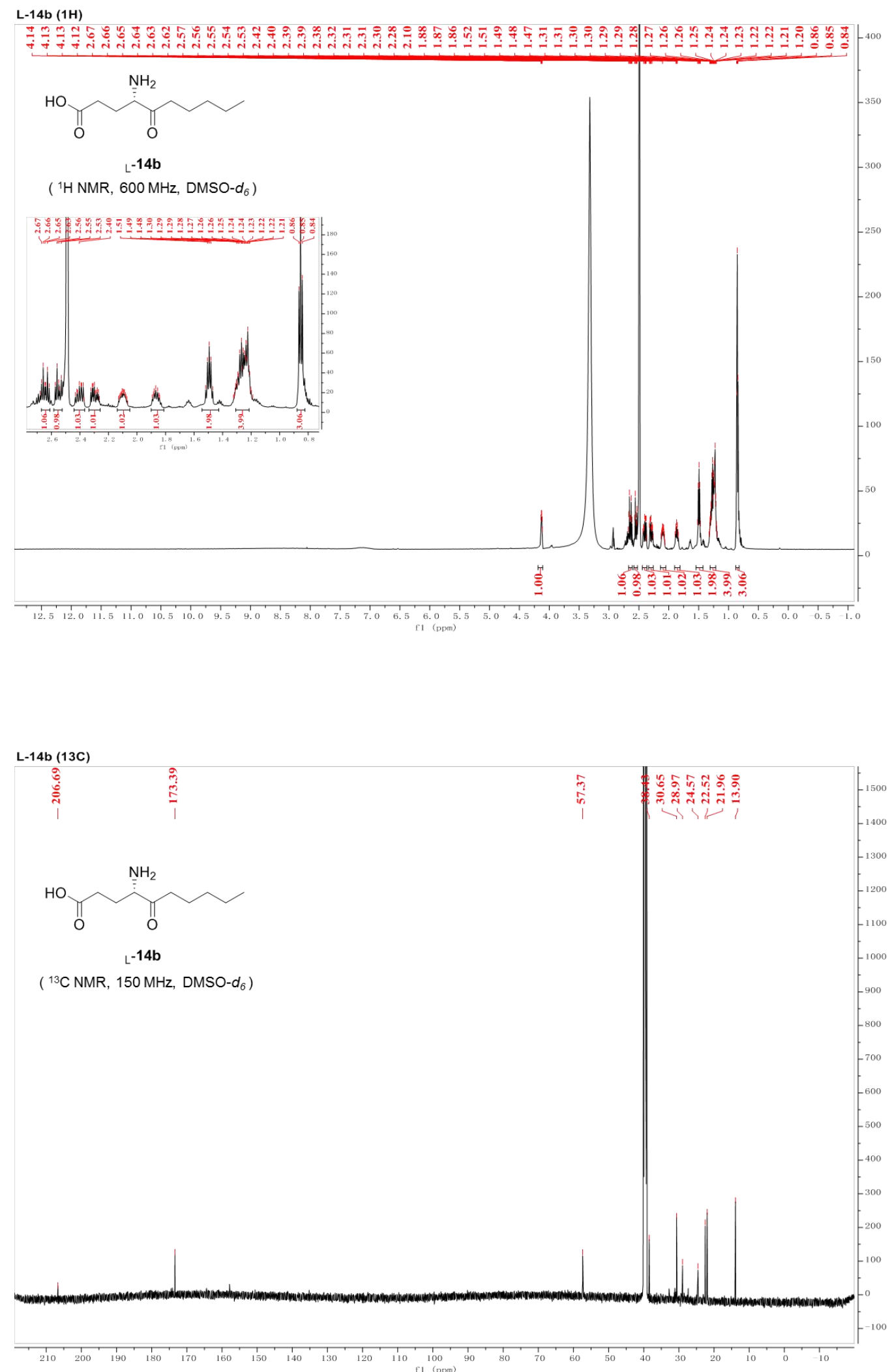
L-14b (13C DEPT)
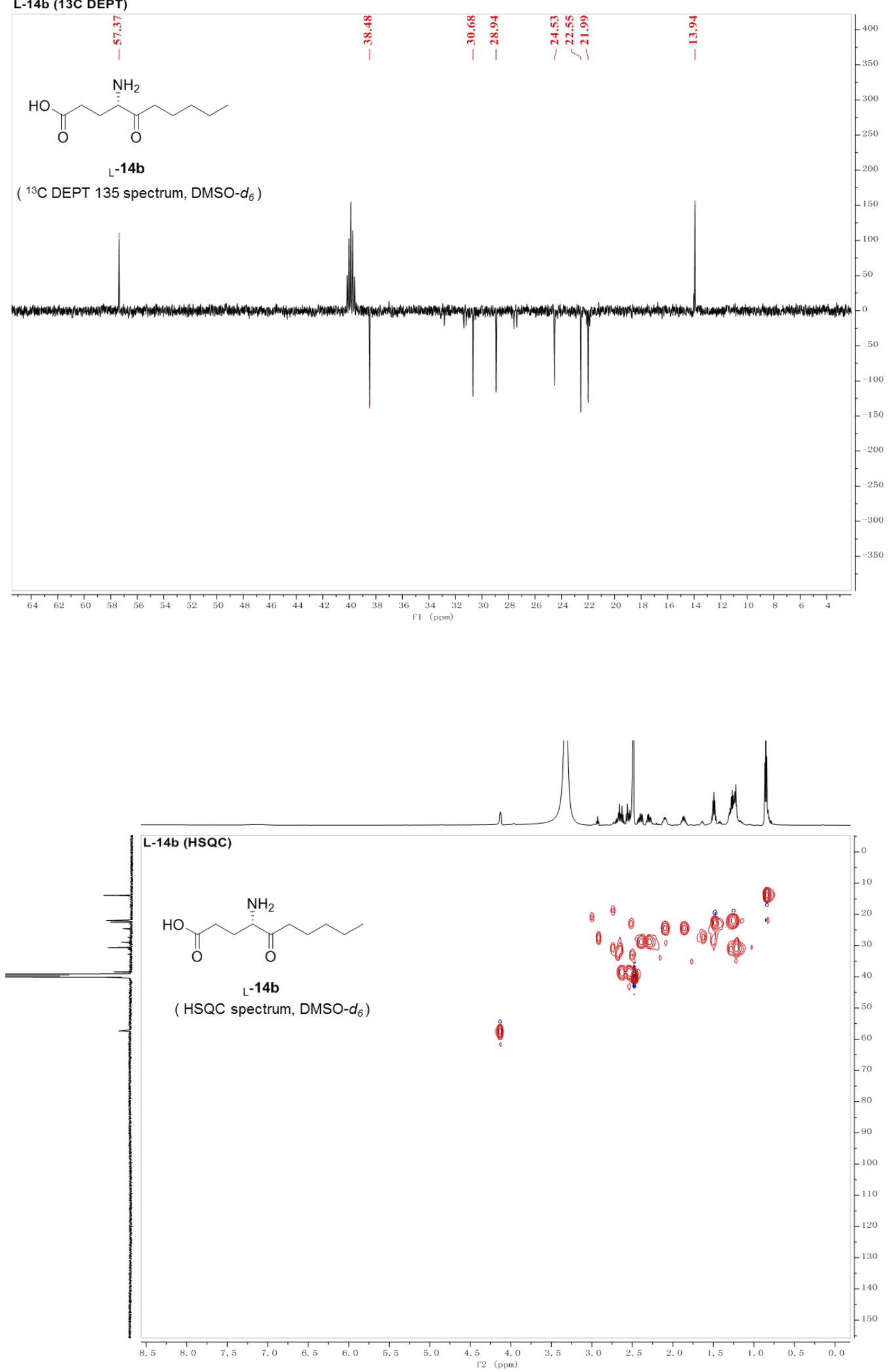

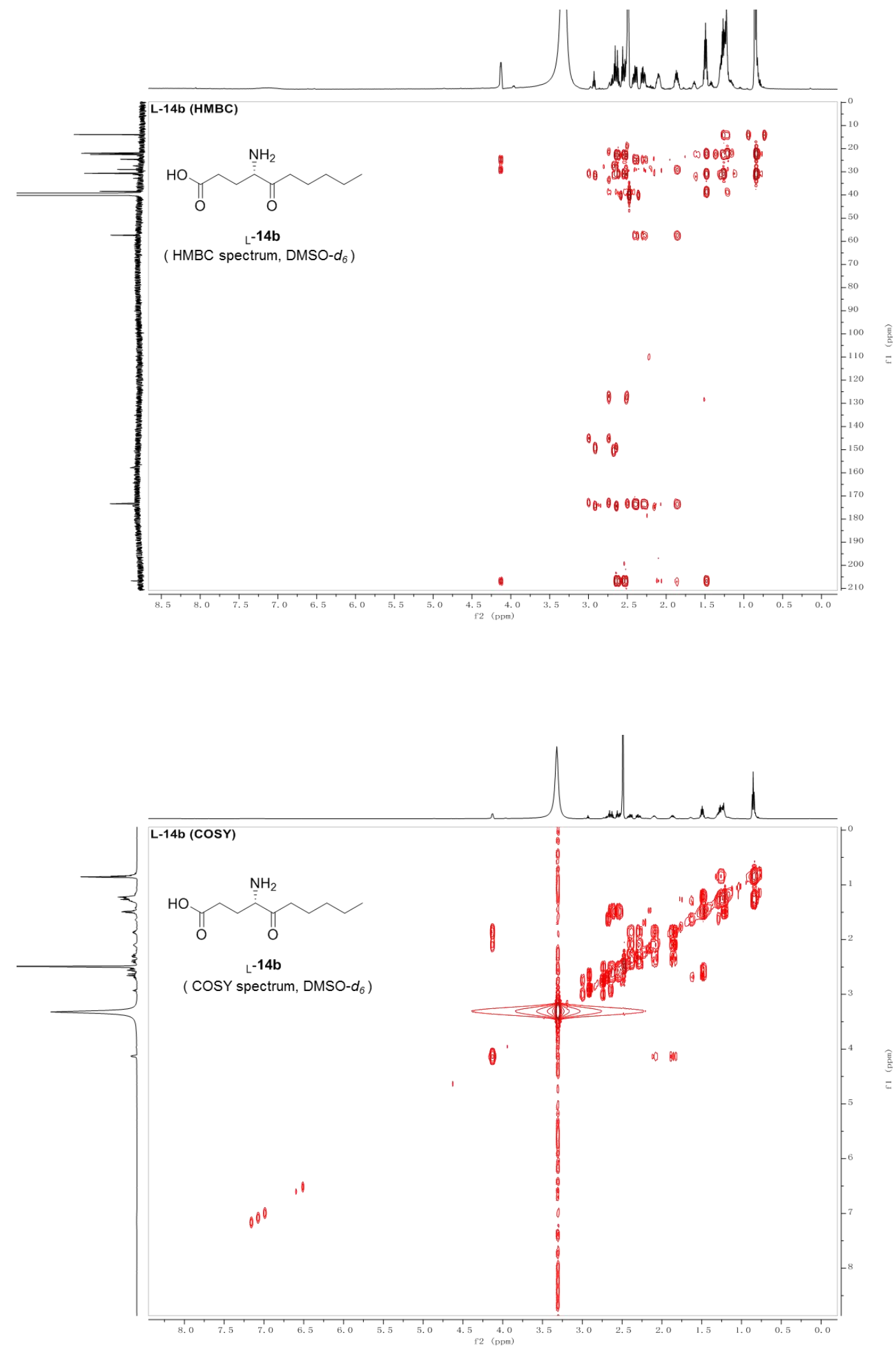


\subsection{7 (S)-4-amino-5-oxoundecanoic acid ( $\mathrm{L}-15 \mathrm{~b})$}

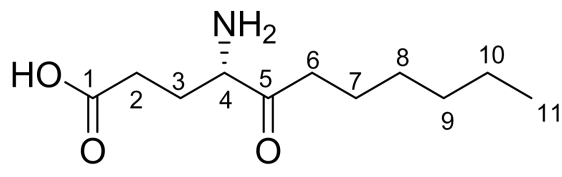

\begin{tabular}{|c|c|c|c|}
\hline $\begin{array}{l}\text { No. } \\
\text { position }\end{array}$ & $\delta_{\mathrm{C}}$, type & $\begin{array}{l}\mathrm{L}^{-\mathbf{1 5 b}} \\
\delta_{\mathrm{H}}, \text { mult }\end{array}$ & $(J$ in $\mathrm{Hz})$ \\
\hline 1 & $173.4, \mathrm{C}$ & & \\
\hline 2 & $28.9, \mathrm{CH}_{2}$ & $2.41, \mathrm{~m}$ & $2.29, \mathrm{~m}$ \\
\hline 3 & 24.6, $\mathrm{CH}_{2}$ & $2.10, \mathrm{~m}$ & $1.88, \mathrm{~m}$ \\
\hline 4 & $57.3, \mathrm{CH}$ & $4.14, \mathrm{~m}$ & \\
\hline 5 & $206.5, \mathrm{C}$ & & \\
\hline 6 & $38.5, \mathrm{CH}_{2}$ & $2.64, \mathrm{~m}$ & $2.55, \mathrm{~m}$ \\
\hline 7 & $22.8, \mathrm{CH}_{2}$ & $1.48, \mathrm{~m}$ & \\
\hline 8 & $28.1, \mathrm{CH}_{2}$ & $1.23, \mathrm{~m}$ & \\
\hline 9 & $31.1, \mathrm{CH}_{2}$ & $1.23, \mathrm{~m}$ & \\
\hline 10 & $22.1, \mathrm{CH}_{2}$ & $1.23, \mathrm{~m}$ & \\
\hline 11 & $14.0, \mathrm{CH}_{3}$ & $0.84, \mathrm{t}(\mathrm{C}$ & \\
\hline
\end{tabular}

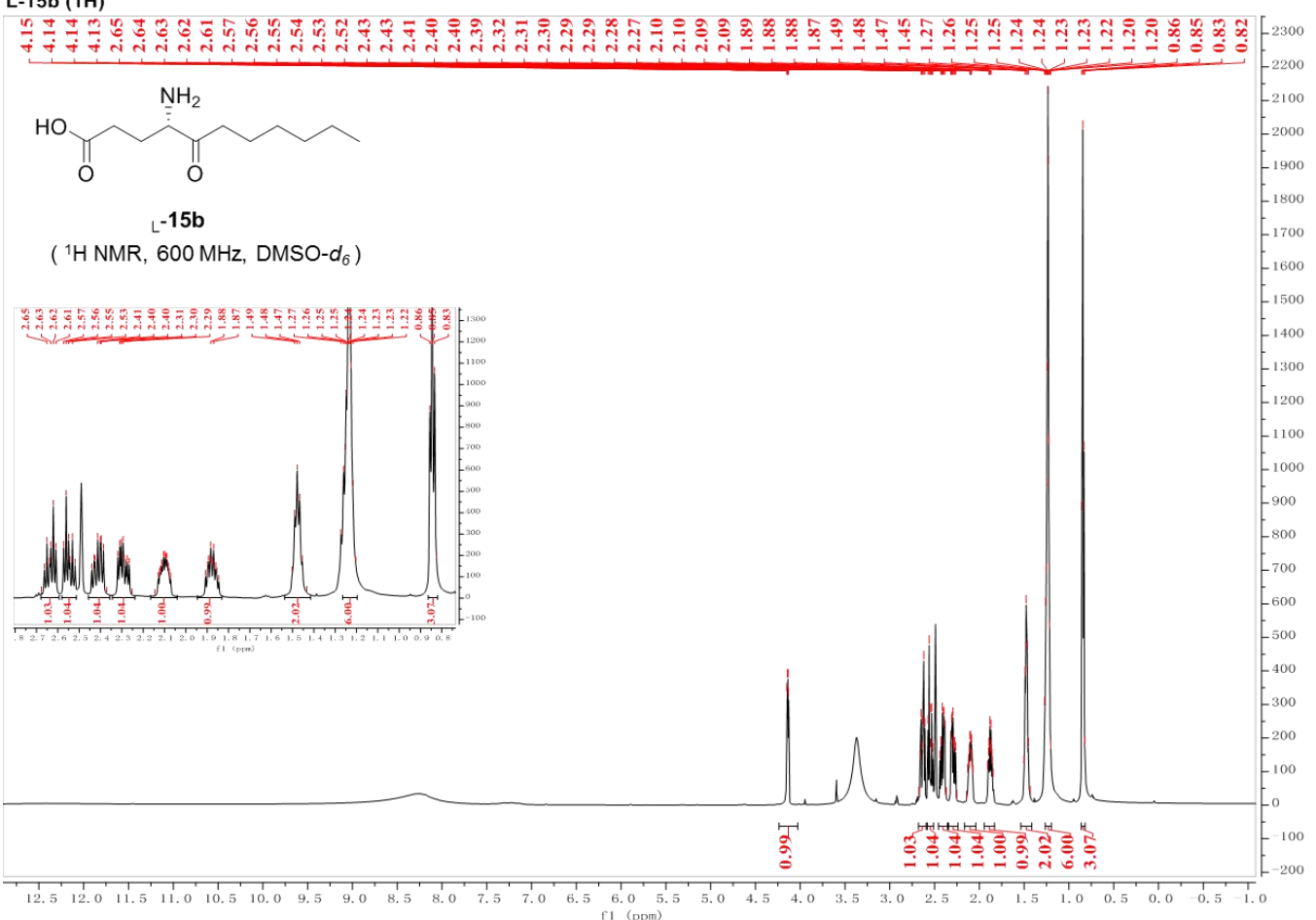



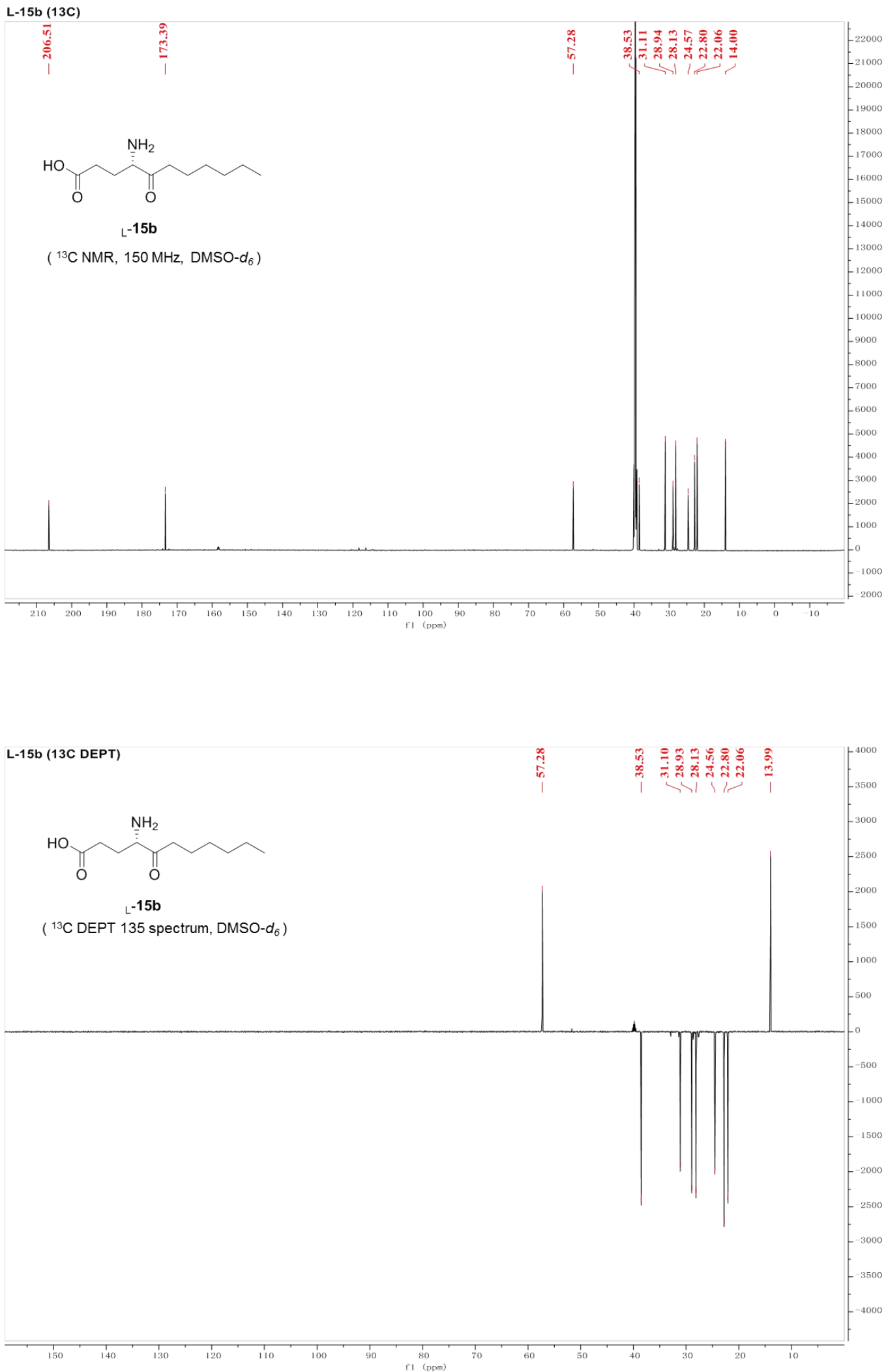

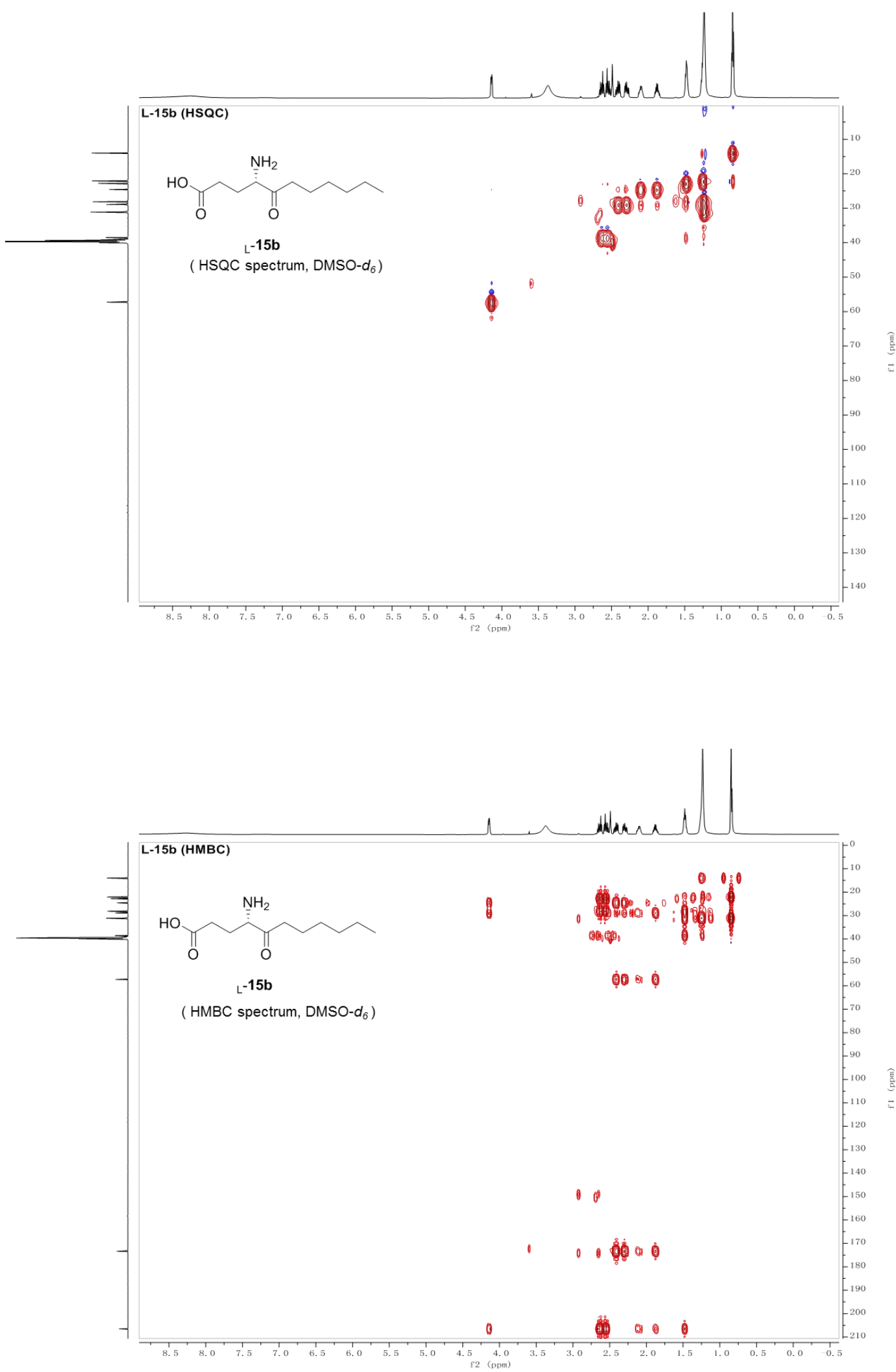


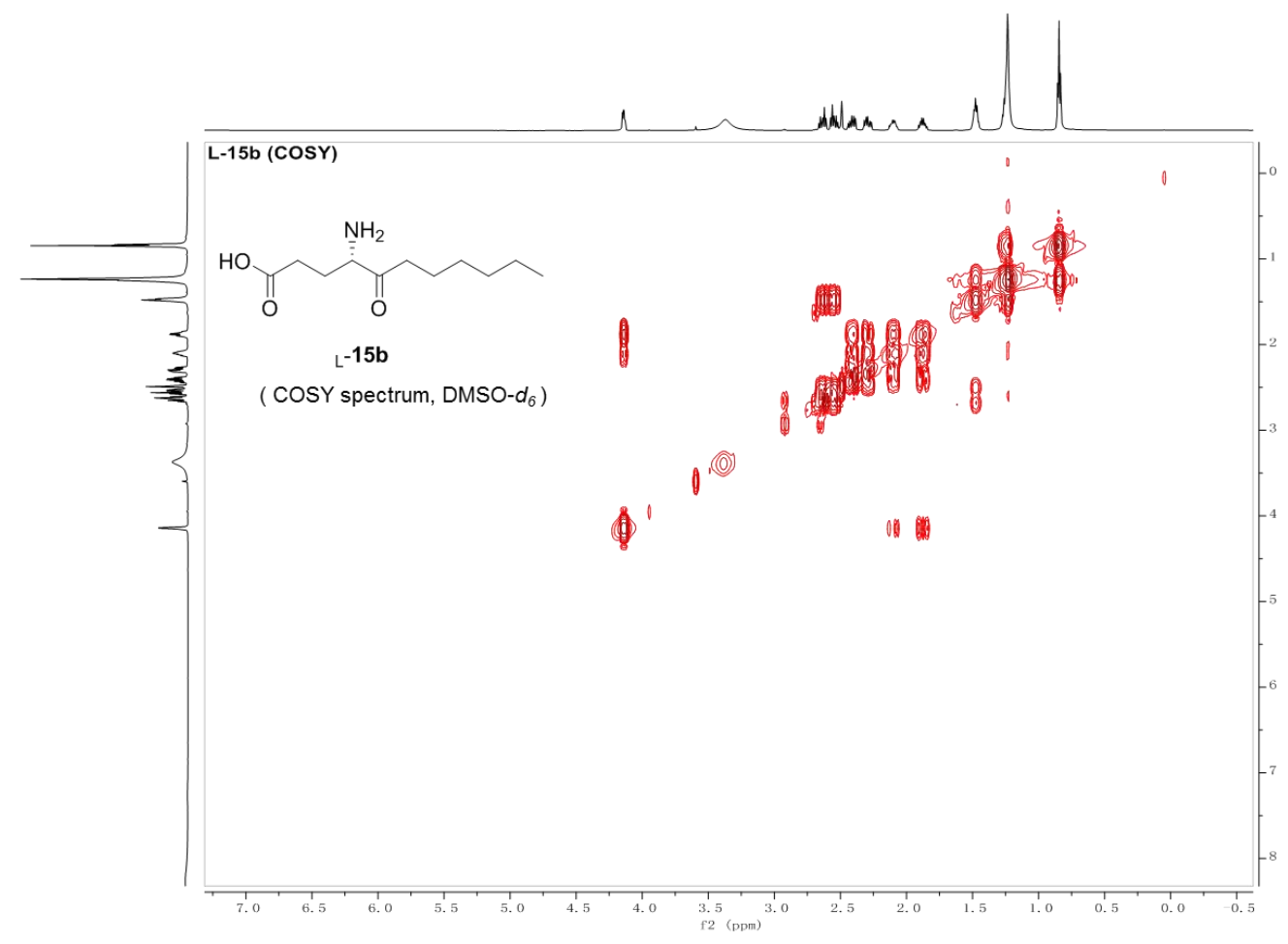

1.3.8 (S)-4-amino-5-oxododecanoic acid (L-16b)

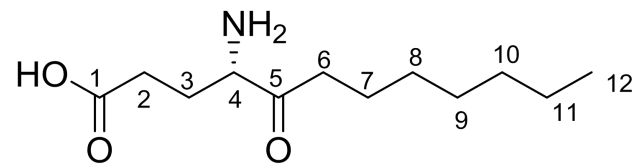

\begin{tabular}{|c|c|c|c|}
\hline $\begin{array}{l}\text { No. } \\
\text { position }\end{array}$ & \multicolumn{3}{|c|}{$L^{-16 b}$} \\
\hline 1 & $173.4, \mathrm{C}$ & & \\
\hline 2 & $28.5, \mathrm{CH}_{2}$ & $2.40, \mathrm{~m}$ & $2.29, \mathrm{~m}$ \\
\hline 3 & 24.6, $\mathrm{CH}_{2}$ & $2.10, \mathrm{~m}$ & $1.86, \mathrm{~m}$ \\
\hline 4 & $57.4, \mathrm{CH}$ & $4.12, \mathrm{~m}$ & \\
\hline 5 & 206.7, C & & \\
\hline 6 & $38.5, \mathrm{CH}_{2}$ & $2.64, \mathrm{~m}$ & $2.54, \mathrm{~m}$ \\
\hline 7 & $22.8, \mathrm{CH}_{2}$ & $1.48, \mathrm{~m}$ & \\
\hline 8 & $28.4, \mathrm{CH}_{2}$ & $1.24, \mathrm{~m}$ & \\
\hline 9 & $22.2, \mathrm{CH}_{2}$ & $1.24, \mathrm{~m}$ & \\
\hline 10 & $31.2, \mathrm{CH}_{2}$ & $1.24, \mathrm{~m}$ & \\
\hline 11 & $22.1, \mathrm{CH}_{2}$ & $1.24, \mathrm{~m}$ & \\
\hline 12 & $14.0, \mathrm{CH}_{3}$ & $0.84, \mathrm{~m}$ & \\
\hline
\end{tabular}



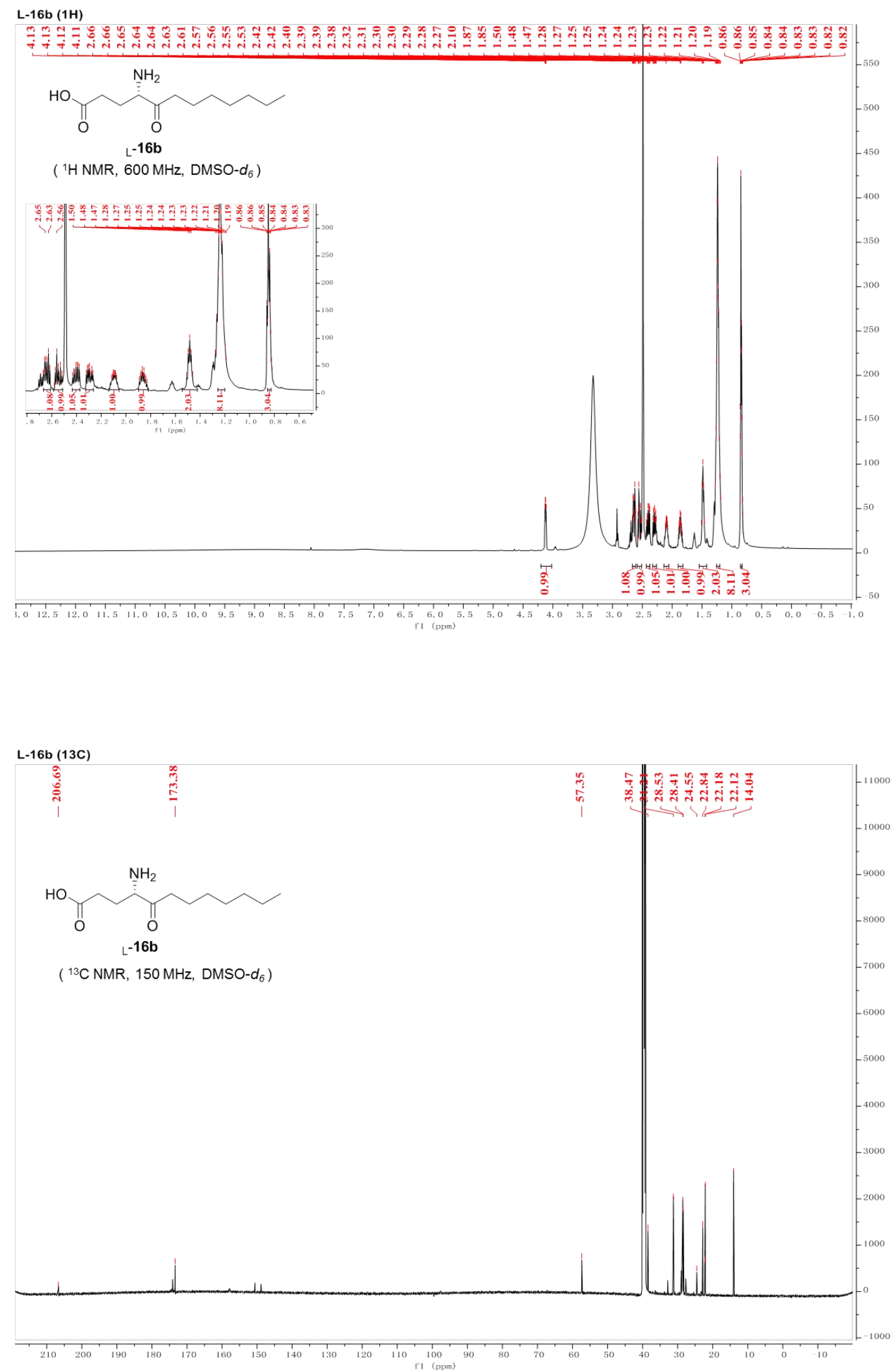

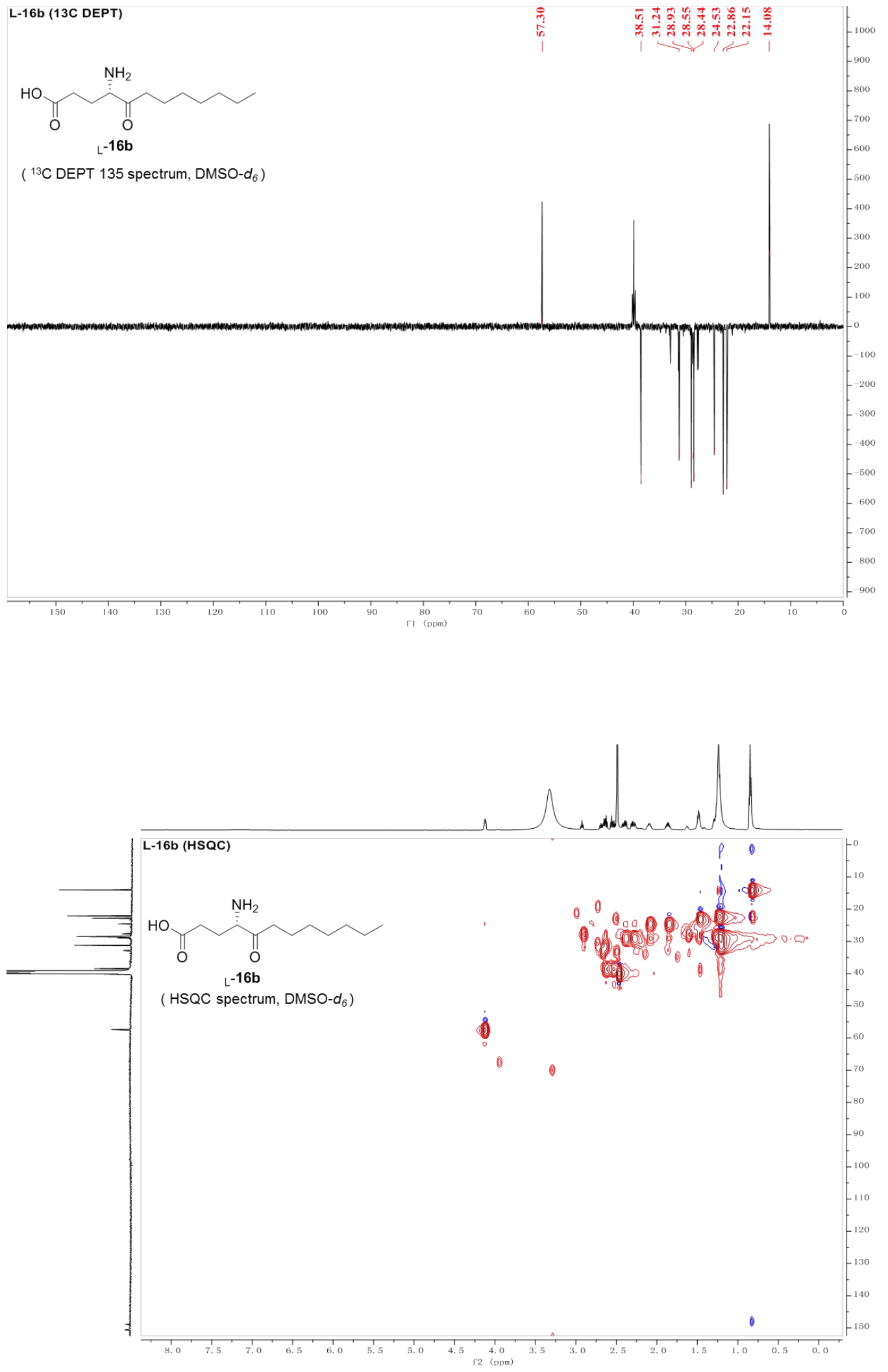

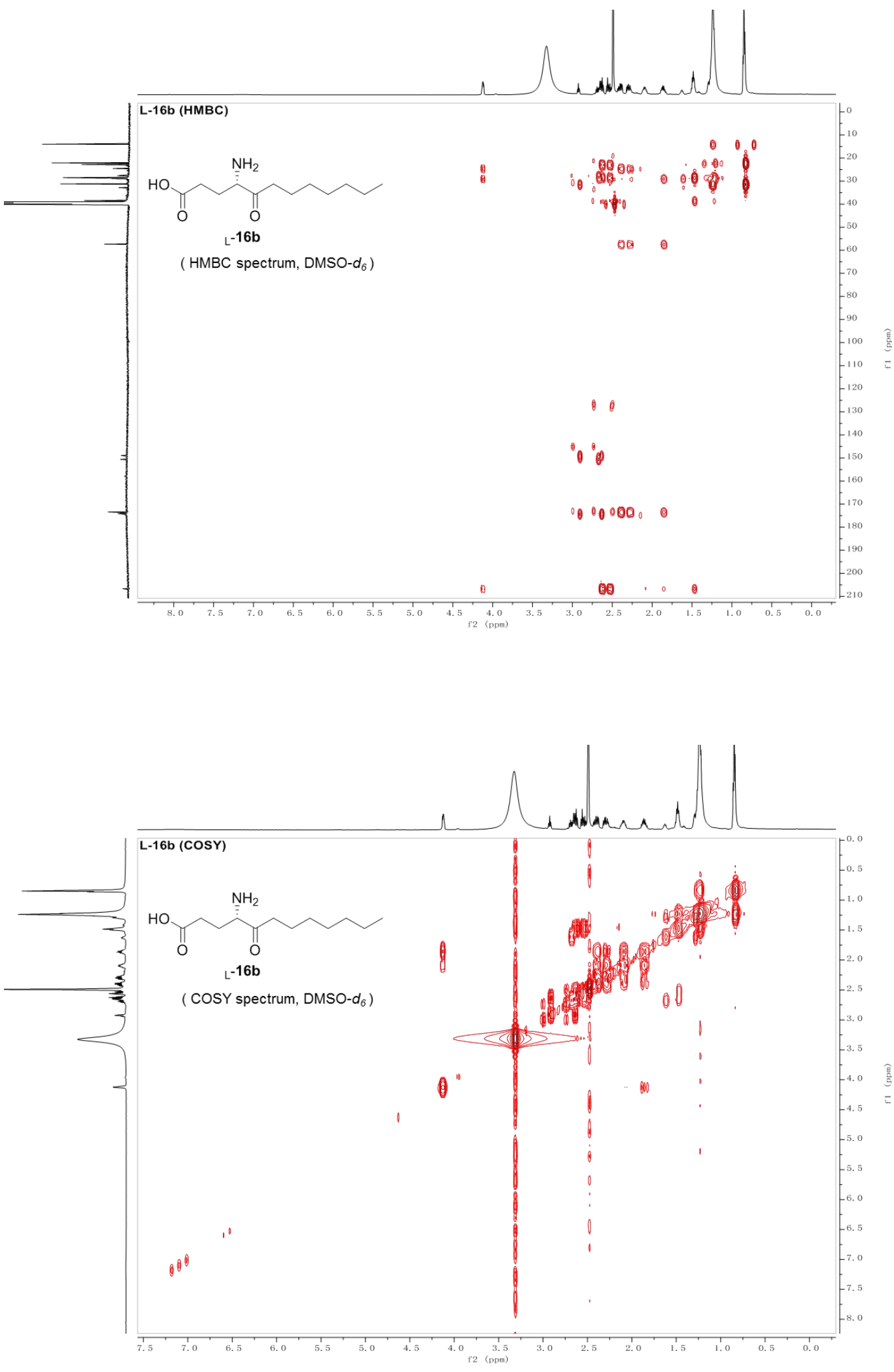


\section{Supporting methods}

\subsection{Strains, plasmids and media}

All strains and plasmids used in this study are listed in Table S11. Streptomyces albogriseolus MGR072 and its derivatives were grown on soya flour medium (SFM) ( $2 \%$ soybean powder, $2 \%$ mannitol, $2 \%$ agar), TSB liquid medium ( $3 \%$ tryptone soya broth) and ISP3 medium (oat flour $20 \mathrm{~g} / \mathrm{L}$, standard salt solution $1 \mathrm{~mL} / \mathrm{L}, \mathrm{pH}$ 7.3). Escherichia coli DH5a and E. coli BL21 (DE3 with chaperone coexpression plasmid pGro7) were used as the cloning host and expression host, respectively. E. coli ET12567 (pUZ8002) was used to drive conjugative transfer of non-methylated DNA to $S$. albogriseolus MGR072. E. coli strains were grown at $37^{\circ} \mathrm{C}$ in Luria-Bertani (LB) medium or on LB plates. When necessary, these media were supplemented with appropriate antibiotics.

\subsection{DNA manipulation and sequence analysis}

All primers used in this study are listed in Table S12. DNA manipulations were performed according to standard procedures for Streptomyces and E. coli. ${ }^{3}$ All the recombinant plasmids were sequenced and testified.

\subsection{Chemicals}

Restriction endonucleases were obtained from Thermo Fisher Scientific (USA). Phusion High-Fidelity Master Mix with GC buffer and Gibson Assembly Master Mix were purchased from Yeasen Biotechnology (China). The synthesis of oligonucleotide primers and DNA sequencing were conducted by Tsingke (China). $\mathrm{L}^{-}{ }^{13} \mathrm{C}_{5},{ }^{15} \mathrm{~N}$-glutamate $\left(\mathrm{L}^{-}{ }^{13} \mathrm{C}_{5},{ }^{15} \mathrm{~N}-\mathrm{Glu}\right)$ was purchased from Cambridge Isotope Laboratories (USA). 3-Methylcrotonyl-CoA, butyryl-CoA, isovaleryl-CoA, Marfey's reagent $\left(N_{\alpha^{-}}\right.$(2,4-dinitro-5-fluorophenyl)-L-alaninamide, FDAA), etc. were purchased 
from Sigma-Aldrich (Switzerland). $\mathrm{MeOH}$ and ACN were purchased from ANPEL (China). Carboxylic acids and adenosine triphosphate (ATP) were purchased from J\&K Scientific (China). Amino acids, HS-CoA, isopropyl $\beta$-D-thiogalactoside (IPTG), antibiotics, 2-[4-(2-hydroxyethyl)piperazin-1-yl]ethanesulfonic acid (Hepes), Tris(hydroxymethyl)aminomethane (Tris-HCl) and other used products were purchased from Sangon Biotech (China).

\subsection{Gene inactivation, complementation and metabolites analysis}

For in-frame gene deletion of alb29, left and right flanking fragments were amplified from the genome of $S$. albogriseolus MGR072 with primer pairs alb29U-F/R (1,570 bp) and alb29D-F/R (1,539 bp). The two purified fragments, alb29U and alb29D, were ligated to the XbaI/HindIII digested pJTU1278 4 plasmid by one-step Gibson assembly ${ }^{5}$ to generate plasmid alb29-pJTU1278. With plasmid pIB139 as the template, aac(3)IV cassette was cloned using primer pair apar-F/R, the purified PCR product was digested by KpnI and ligated into corresponding sites of the plasmid alb29-pJTU1278, resulting in plasmid pD-29. pD-29 was then transferred into the strain S. albogriseolus MGR072 via E. coli ET12567/pUZ8002 by conjugation. After incubation on a SFM plate at $30{ }^{\circ} \mathrm{C}$ for $14 \mathrm{~h}$, the plate was overlaid with apramycin $(1 \mathrm{mg})$ and nalidixic acid $(1 \mathrm{mg})$ to screen apramycin-resistant exconjugants. Second crossover events were expected after a round of nonselective growth of the initial apramycin-resistance exconjugants and checked by PCR using the corresponding pair primers alb29T-F/R (1,039 bp for alb29 deletion).

The promoter of $h r d B$ (RNA polymerase principal sigma factor, accession no. GES33466.1) was reported that can be used for the expression of the target gene in Streptomyces. ${ }^{6}$ Thus, orf2284 (accession no. MN641124) that shows 99\% identities with the $h r d B$ was identified in S. albogriseolus MGR072. Then, the promoter region of orf2284 (upstream 502 bp DNA sequence of orf2284) (Table S13) was cloned from genome DNA and further ligated with the XbaI/BamHI digested pSET152 plasmid 
fragment by the one-step assembly, generating the plasmid pHrdB. To complement alb29 in the strain $\Delta a l b 29$, the whole alb29 gene sequence (1,224 bp) was amplified by PCR using primers alb29-pHrdB-F/R. The fragment was then cloned into the $N d e \mathrm{I} / E c o$ RI site of $\mathrm{pHrdB}$ to generate the recombinant plasmid $\mathrm{pHrdB}-29$. It was then transferred into $\Delta a l b 29$ by conjugation to obtain the strain $\Delta a l b 29:: \mathrm{pHrdB}-29$.

For metabolites analysis, the S. albogriseolus MGR072 (wild type strain), strain $\Delta a l b 29$ and strain $\Delta a l b 29:: \mathrm{pHrdB}-29$ were cultured in $100 \mathrm{~mL}$ ISP3 medium at $30^{\circ} \mathrm{C}$, $220 \mathrm{rpm}$ for 7 days. After centrifugation (9000 rpm, $3 \mathrm{~min}$ ), the supernatant of fermentation broth was harvested and then extracted twice with an equal volume of ethyl acetate. The organic layers were enriched and dried under reduced pressure to obtain the crude extracts. Then these crude extracts were dissolved in $\mathrm{MeOH}$ and further analyzed on a Prominence Module HPLC system (Shimadzu) with an Agilent C18 column $(150 \times 4.6 \mathrm{~mm}, 5 \mu \mathrm{m})$ at a flow rate of $1 \mathrm{~mL} / \mathrm{min}$ using a mobile phase of (A) water with $0.05 \%$ TFA and (B) ACN with $0.05 \%$ TFA. The following gradient was used: $10 \% \mathrm{~B}$ from 0 to $5 \mathrm{~min}, 10 \%-50 \% \mathrm{~B}$ from 5.01 to $25 \mathrm{~min}, 100 \% \mathrm{~B}$ from 25.01 to $28 \mathrm{~min}, 10 \% \mathrm{~B}$ from 28.01 to $35 \mathrm{~min}$ (detection at $190-800 \mathrm{~nm}$ ).

\subsection{Multiple sequence alignment and phylogenetic analysis}

Multiple sequence alignment of Alb29, AONS, ALAS, KBL, CqsA and KtmB was performed based on MUSCLE at EBI with default parameters (http://www.ebi.ac.uk/Tools/msa/muscle/) and then analyzed by ESPript 3.0 (http://espript.ibcp.fr/ESPript/ESPript/). Phylogenetic analyses were conducted in MEGA7, ${ }^{7}$ using the maximum likelihood method with 500 bootstrap replications based on the JTT matrix-based model. ${ }^{8}$ The phylogenetic tree was further edited by EvolView. ${ }^{9}$ The accession numbers of related proteins were listed in Table S14. 


\subsection{Cloning, expression and purification of recombinant proteins}

DNA fragments of alb29 and mgr36 were amplified from the genome of $S$. albogriseolus MGR072 by PCR using corresponding primers. The PCR products were ligated into the EcoRI/BamHI sites of pET28a by one step cloning, respectively, to obtain plasmids pET28a-29 and pET28a-36. Each plasmid was then transformed into E. coli BL21 (DE3 with chaperone coexpression plasmid pGro7) for protein expression. Each transformant was grown in $2 \mathrm{~L} \mathrm{LB}$ medium containing $25 \mu \mathrm{g} / \mathrm{mL}$ chloramphenicol and $50 \mu \mathrm{g} / \mathrm{mL}$ kanamycin at $37^{\circ} \mathrm{C}$ and $220 \mathrm{rpm}$, until $\mathrm{OD}_{600}$ reached 0.4-0.6. Afterward, for Alb29, IPTG was added to a final concentration of $0.2 \mathrm{mM}$. The culture was shaken at $16^{\circ} \mathrm{C}$ for $20 \mathrm{~h}$, harvested by centrifugation $(8000 \mathrm{rpm}, 3$ min) at $4{ }^{\circ} \mathrm{C}$, and resuspended in buffer $\mathrm{A}(20 \mathrm{mM}$ potassium phosphate (PBK), pH 8.0, $0.1 \mathrm{mM}$ pyridoxal-5'-phosphate (PLP), 10\% glycerol). The cell was lysed by ultrasonication on ice, and the supernatant was further centrifuged by centrifugation (9000 rpm, $60 \mathrm{~min}$ ) at $4{ }^{\circ} \mathrm{C}$. The supernatant was used to purify target protein by nickel-affinity chromatography with standard procedures. The protein was eluted with buffer B (20 mM PBK, pH 8.0, 0.1 mM PLP, 10\% glycerol, 500 mM imidazole).

Expression of Mgr36 was induced with IPTG at a final concentration of $1 \mathrm{mM}$ when the $\mathrm{OD}_{600}$ value reached 0.4-0.6 and the cell growth was resumed at $18{ }^{\circ} \mathrm{C}$ for $20 \mathrm{~h}$. Cells were harvested by centrifugation $(8000 \mathrm{rpm}, 3 \mathrm{~min})$ at $4{ }^{\circ} \mathrm{C}$ and resuspended in buffer $\mathrm{C}(20 \mathrm{mM}$ Tris- $\mathrm{HCl}, \mathrm{pH} 8.0,500 \mathrm{mM} \mathrm{NaCl}, 10 \%$ glycerol). After lysis by ultrasonication, the cell debris was removed by centrifugation (9000 $\mathrm{rpm}, 60 \mathrm{~min}$ ) at $4{ }^{\circ} \mathrm{C}$. The supernatant was used to purify target protein by nickel-affinity chromatography with standard procedures. The protein was eluted with buffer D (20 mM Tris-HCl, pH 8.0, 500 mM NaCl, 10\% glycerol, 500 mM imidazole). All protein samples were desalted and concentrated using Centrifugal Filter Units (Millipore, Regenerated Cellulose 10,000 MWCO). Purified proteins were checked by sodium dodecyl sulfate-polyacrylamide gel electrophoresis (SDS-PAGE) analysis and 
then stored at $-80{ }^{\circ} \mathrm{C}$. The concentration of protein was determined by Bradford protein quantification assay with bovine serum albumin (BSA) as the standard.

\subsection{Enzymatic assay of Alb29}

General enzymatic assay of Alb29 was carried out in a $100 \mu \mathrm{L}$ scale with $10 \mu \mathrm{M}$ Alb29, $100 \mu \mathrm{M}$ PLP, $1 \mathrm{mM}$ L-Glu (or $\mathrm{L}^{-}{ }^{13} \mathrm{C}_{5},{ }^{15} \mathrm{~N}-\mathrm{Glu}$, or other amino acids), $200 \mu \mathrm{M}$ 2a (or 3a, or 4a, or 12a, or 14a, or 16a) and $20 \mathrm{mM} \mathrm{PBK}$ buffer $(\mathrm{pH} 8.0)$ at $30{ }^{\circ} \mathrm{C}$ for $2 \mathrm{~h}$. The reaction was then terminated by the addition of an equal volume of chloroform. Protein was removed by centrifugation (12000 rpm, $5 \mathrm{~min}$ ). $80 \mu \mathrm{L}$ of the supernatant was transferred into a sample bottle for HPLC, UPLC-HRMS or FDAA derivatization analysis.

HPLC analysis was performed on XSelect-HSS T3 column (Waters, $150 \times 4.6 \mathrm{~mm}$, $5 \mu \mathrm{m})$ at a flow rate of $0.8 \mathrm{~mL} / \mathrm{min}$ using a mobile phase of (A) water with $0.05 \%$ TFA and (B) ACN with $0.05 \%$ TFA. The following gradient was used: $2 \%$ B from 0 to $5 \mathrm{~min}, 2 \%-80 \% \mathrm{~B}$ from 5.01 to $30 \mathrm{~min}, 100 \% \mathrm{~B}$ from 30.01 to $35 \mathrm{~min}, 2 \% \mathrm{~B}$ from 35.1 to $43 \mathrm{~min}$ (detection at $190-800 \mathrm{~nm}$ ).

UPLC-HRMS analysis was performed using a Waters Acquity UPLC system equipped with a Micromass Q-TOF Premier mass spectrometer (Waters MS Technologies, Manchester, UK). Chromatographic separations were performed on a $2.1 \times 100 \mathrm{~mm}(1.7 \mu \mathrm{m})$ Acquity BEH C18 chromatography column. The column temperature was set at $45{ }^{\circ} \mathrm{C}$. The gradient elution program started from $2 \% \mathrm{D}$, changed to $10 \% \mathrm{D}$ within $2.5 \mathrm{~min}$, to $30 \% \mathrm{D}$ within $5 \mathrm{~min}$, to $100 \% \mathrm{D}$ within $4 \mathrm{~min}$, and was finally held at $100 \% \mathrm{D}$ for $2 \mathrm{~min}$ (solvent C: water with $0.1 \%$ formic acid; solvent D: ACN containing $0.1 \%$ formic acid). The flow rate was $0.40 \mathrm{~mL} / \mathrm{min}$. The eluate was directed to the mass spectrometer without splitting. Mass analysis was performed using a Q-TOF mass spectrometer equipped with an ESI source operating in the negative ion modes. 


\subsection{Enzymatic assay of Mgr36}

General enzymatic assay of Mgr36 was carried out in a $100 \mu \mathrm{L}$ scale with $20 \mu \mathrm{M}$ Mgr36, $10 \mathrm{mM} \mathrm{MgCl}$, $7 \mathrm{mM}$ ATP, $5 \mathrm{mM}$ dithiothreitol (DTT), 0.1\% Triton X-100, $300 \mu \mathrm{M}$ HS-CoA, $1 \mathrm{mM}$ carboxylic acid and $20 \mathrm{mM}$ PBK buffer (pH 8.0) at $30{ }^{\circ} \mathrm{C}$ for $2 \mathrm{~h}$. The subsequent processing and analytical method were the same as the general enzymatic assay of Alb29 described in $\mathbf{2 . 7}$.

\subsection{In vitro assay of one-pot two-step cascade reaction with Alb29 and Mgr36}

General enzymatic assay was carried out in a $100 \mu \mathrm{L}$ scale with $20 \mu \mathrm{M}$ Alb29, 20 $\mu \mathrm{M}$ Mgr36, $100 \mu \mathrm{M}$ PLP, $10 \mathrm{mM} \mathrm{MgCl} 2,7 \mathrm{mM}$ ATP, $5 \mathrm{mM}$ DTT, 0.1\% Triton $\mathrm{X}-100,300 \mu \mathrm{M}$ HS-CoA, $10 \mathrm{mM}$ L-Glu (or $\mathrm{L}^{-}{ }^{13} \mathrm{C}_{5},{ }^{15} \mathrm{~N}-\mathrm{Glu}$ ), $10 \mathrm{mM}$ carboxylic acid and $20 \mathrm{mM}$ PBK buffer ( $\mathrm{pH} 8.0)$ at $30{ }^{\circ} \mathrm{C}$ for $2 \mathrm{~h}$. The subsequent processing and analytical method were the same as the general enzymatic assay of Alb29 described in 2.7, except for the gradient elution program of UPLC-HRMS analysis of the reaction using 7, 12-16 as substrates. The following gradient was used (solvent C: water with $0.1 \%$ formic acid; solvent D: ACN containing $0.1 \%$ formic acid): $0 \% \mathrm{D}$ from 0 to 0.5 $\min , 0 \%-10 \% \mathrm{D}$ from 0.5 to $2 \mathrm{~min}, 10 \%-50 \% \mathrm{D}$ from 2.0 to $4.5 \mathrm{~min}, 50 \%-100 \% \mathrm{D}$ from 4.5 to $6.0 \mathrm{~min}, 100 \% \mathrm{D}$ from 6.0 to $7.4 \mathrm{~min}, 0 \% \mathrm{D}$ from $7.4-9.0 \mathrm{~min}$. The flow rate was $0.40 \mathrm{~mL} / \mathrm{min}$.

\subsection{Derivatization of $\alpha$-amino ketones with Marfey's reagent}

The supernatants $(40 \mu \mathrm{L})$ from different reaction mixtures, i.e., Alb29 reaction or one-pot reaction, were obtained and treated with $80 \mu \mathrm{L}$ 1\% FDAA in acetone and 16 $\mu \mathrm{L} 1 \mathrm{M}$ sodium bicarbonate at $40{ }^{\circ} \mathrm{C}$ for $5 \mathrm{~min}$. Afterward, $8 \mu \mathrm{L} 2 \mathrm{M} \mathrm{HCl}$ was added to terminate the derivatization reaction. The supernatant $(100 \mu \mathrm{L})$ was transferred into a sample bottle for HPLC and UPLC-HRMS analysis. 
HPLC analysis was performed on an extend-C18 reversed phase column (Agilent, $150 \times 4.6 \mathrm{~mm}, 5 \mu \mathrm{m}$ ) at a flow rate of $1 \mathrm{~mL} / \mathrm{min}$, monitored at 190-800 nm wavelength. The gradient elution program of $\mathbf{2 b}$-FDAA, 3b-FDAA, 4b-FDAA, 8b-FDAA, 13b-FDAA, and 15b-FDAA, 16b-FDAA derivatives was following (solvent A: water with $0.05 \%$ TFA; solvent B: ACN containing 0.05\% TFA): 0-5 min 5\% solvent B; 5-38 min 5\%-54.2\% solvent B; 38.1-43 min 100\% solvent B; 43.1-50 min $5 \%$ solvent $B$. The gradient elution program of $\mathbf{5 b}$-FDAA, 7b-FDAA, and 12b-FDAA derivatives was $0-5 \min 5 \%$ solvent $\mathrm{B}$; $5-40$ min 5\%-80\% solvent $\mathrm{B}$; 40.1-45 $\min 80 \%$ solvent $\mathrm{B} ; 45.01-53 \min 5 \%$ solvent B. The gradient elution program of $14 \mathbf{b}-F D A A$ derivatives was $0-5 \min 5 \%$ solvent $\mathrm{B}$; $5-58 \min 5 \%-54.2 \%$ solvent B; 58.1-63 min 100\% solvent B; 63.01-70 min 5\% solvent B.

UPLC-HRMS analysis was performed on a Waters Acquity UPLC system equipped with a Micromass Q-TOF Premier mass spectrometer (Waters MS Technologies, Manchester, UK). Chromatographic separations were performed on a $2.1 \times 100 \mathrm{~mm}(1.7 \mu \mathrm{m})$ Acquity BEH C18 chromatography column. The column temperature was set at $45{ }^{\circ} \mathrm{C}$. The gradient elution program started from $5 \% \mathrm{D}$, changed to $30 \% \mathrm{D}$ within $2.5 \mathrm{~min}$, to $60 \% \mathrm{D}$ within $5 \mathrm{~min}$, to $100 \% \mathrm{D}$ within $4 \mathrm{~min}$, and was finally held at $100 \% \mathrm{D}$ for 2 min (solvent C: water of $0.1 \%$ formic acid; solvent D: ACN containing $0.1 \%$ formic acid). The flow rate was $0.40 \mathrm{~mL} / \mathrm{min}$. The eluate was directed to the mass spectrometer without splitting. Mass analysis was performed using a Q-TOF mass spectrometer equipped with an ESI source operating in the positive ion modes.

\subsection{Time-course analysis of $2 \mathrm{~b}$, based on Marfey's reagent derivatization}

Firstly, $500 \mu \mathrm{L}$ reaction mixture $(20 \mathrm{mM}$ PBK buffer, $\mathrm{pH}$ 8.0, $10 \mu \mathrm{M}$ Alb29, 100 $\mu \mathrm{M}$ PLP, $2 \mathrm{mM}$ L-Glu, $200 \mu \mathrm{M}$ 2a) or (20 mM PBK buffer, pH 8.0, $10 \mu \mathrm{M}$ Alb29, $100 \mu \mathrm{M}$ PLP, $200 \mu \mathrm{M}$ synthetic ${ }_{\mathrm{L}}-\mathbf{2} \mathbf{b}$ ) was performed in a $2.0 \mathrm{~mL}$ tube heated in the water bath at $30{ }^{\circ} \mathrm{C}$. The reaction mixture $(50 \mu \mathrm{L})$ was taken at a series of time points 
(1 $\mathrm{min}, 7.5 \mathrm{~min}, 15 \mathrm{~min}, 30 \mathrm{~min}, 1 \mathrm{~h}, 2 \mathrm{~h}, 4 \mathrm{~h}$ and $8 \mathrm{~h}$ ) for time-course analysis. The reaction was quenched by adding an equal volume of chloroform. Protein was removed by centrifugation $(12000 \mathrm{rpm}, 2 \mathrm{~min})$. The supernatant $(40 \mu \mathrm{L})$ was then obtained and treated with $80 \mu \mathrm{L} 1 \%$ FDAA in acetone and $16 \mu \mathrm{L} 1 \mathrm{M}$ sodium bicarbonate at $40{ }^{\circ} \mathrm{C}$ for $5 \mathrm{~min}$. Afterward, $8 \mu \mathrm{L} 2 \mathrm{M} \mathrm{HCl}$ was added to terminate the derivatization reaction. The supernatant $(100 \mu \mathrm{L})$ was transferred into a sample bottle for HPLC and UPLC-HRMS analysis. The analytical method was the same as the method described in $\mathbf{2 . 1 0}$. Then, the ratio of ${ }_{\mathrm{L}}-\mathbf{2 b}-\mathrm{FDAA}$ : $\mathrm{D}-\mathbf{2 b}$-FDAA was calculated based on the peak area of FDAA derivatives at $325 \mathrm{~nm}$ wavelength.

\subsection{Effects of temperature and buffer on the racemization of ${ }_{\mathrm{L}}-2 \mathrm{~b}$}

The $100 \mu \mathrm{L}$ mixture containing 20 mM PBK buffer (pH 8.0), $10 \mu \mathrm{M}$ Alb29, 100 $\mu \mathrm{M}$ PLP and $200 \mu \mathrm{M}$ synthetic $\mathrm{L}_{\mathbf{2}} \mathbf{2 b}$ was incubated for $2 \mathrm{~h}$ at different temperatures $\left(10,20,25,30,35,40\right.$ and $\left.50{ }^{\circ} \mathrm{C}\right)$. Then, the mixture was derivatized with FDAA reagent. The subsequent processing and analysis method were the same as the general assay described in $\mathbf{2 . 1 0}$. The ratio of ${ }_{\mathrm{L}}-\mathbf{2} \mathbf{b}-\mathrm{FDAA}$ : ${ }_{\mathrm{D}}-\mathbf{2} \mathbf{b}-\mathrm{FDAA}$ was calculated based on the peak area of FDAA derivatives at $325 \mathrm{~nm}$ wavelength.

Effect of buffer on the racemization of ${ }_{\mathrm{L}} \mathbf{- 2} \mathbf{b}$ was tested. The $100 \mu \mathrm{L}$ mixture $(10$ $\mu \mathrm{M}$ Alb29, $100 \mu \mathrm{M}$ PLP, $200 \mu \mathrm{m}$ synthetic $\mathrm{L}-\mathbf{2 b}, 20 \mathrm{mM}$ different buffer (PBK, Hepes, Tris- $\mathrm{HCl} ; \mathrm{pH} \mathrm{8.0),} \mathrm{was} \mathrm{incubated} \mathrm{for} 2 \mathrm{~h}$ at $30^{\circ} \mathrm{C}$. Then, the mixture was derivatized with FDAA. The subsequent processing and analysis method were the same as the general assay in $\mathbf{2 . 1 0}$. The ratio of ${ }_{\mathrm{L}}-\mathbf{2 b}$-FDAA: ${ }_{\mathrm{D}}-\mathbf{2 b}-\mathrm{b}$-FAA was calculated based on the peak area of FDAA derivatives at $325 \mathrm{~nm}$ wavelength.

\subsection{The analysis of Alb29 ultraviolet-visible spectra}

To detect the ultraviolet-visible (UV-vis) absorption of purified recombinant Alb29, we dissolved the enzyme in $20 \mathrm{mM}$ PBK buffer (pH 8.0, with $100 \mu \mathrm{M}$ PLP) with a final concentration of $20 \mu \mathrm{M}$. Spectral measurement was conducted at wavelength 
ranging from 300 to $600 \mathrm{~nm}$ by a microplate reader (BioTek\&Epoch, USA) at room temperature.

\subsection{Effect of pH on Alb29 enzymatic activity}

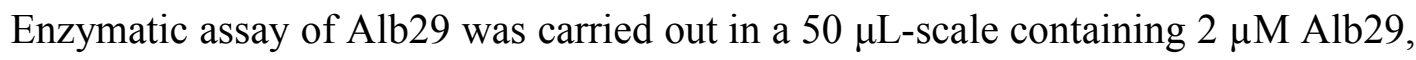
$100 \mu \mathrm{M}$ PLP, $1 \mathrm{mM}_{\mathrm{L}}$-Glu and $100 \mu \mathrm{M} 2 \mathbf{2}$ in $20 \mathrm{mM}$ PBK with different $\mathrm{pH}$ value, at $30{ }^{\circ} \mathrm{C}$ for $15 \mathrm{~min}$. The $\mathrm{pH}$ scale ranged from 6.0 to $12(6.0,6.5,7.0,7.5,8.0,8.5,9.0$, $9.5,10,10.5,11,11.5$ and 12). The reaction was terminated by adding an equal volume of chloroform. Proteins were removed by centrifugation (12000 rpm, $5 \mathrm{~min}$ ). $40 \mu \mathrm{L}$ of the supernatant was transferred into a sample bottle for HPLC analysis, targeting on $\mathbf{2 b}$. The peak area of product $\mathbf{2 b}$ at $254 \mathrm{~nm}$ was measured to evaluate the enzymatic activity. Reactions were run in triplicate.

\subsection{Effect of temperature on Alb29 enzymatic activity}

Enzymatic assay of Alb29 activity was carried out in a $50 \mu \mathrm{L}$-scale with $0.4 \mu \mathrm{M}$ Alb29, $100 \mu \mathrm{M}$ PLP, $10 \mathrm{mM}$ L-Glu and $100 \mu \mathrm{M}$ 2a in $20 \mathrm{mM}$ PBK with a $\mathrm{pH}$ of 9.0, on different temperature for $8 \mathrm{~min}$. The temperature ranged from 20 to $75^{\circ} \mathrm{C}(20,25$, $30,35,40,45,50,55,60,65,70$ and $\left.75^{\circ} \mathrm{C}\right)$. The reaction was terminated by adding an equal volume of chloroform. Proteins were removed by centrifugation (12000 rpm, $5 \mathrm{~min})$. The supernatant $(40 \mu \mathrm{L})$ was transferred into a sample bottle for HPLC analysis, targeting on $\mathbf{2 b}$. The peak area of product $\mathbf{2 b}$ at $254 \mathrm{~nm}$ was measured to evaluate the enzymatic activity. Reactions were run in triplicate

\subsection{Kinetic analyses of Alb29 towards ${ }_{\mathrm{L}}-\mathrm{Glu}, 2 \mathrm{a}, 3 \mathrm{a}, 4 \mathrm{a}, 12 \mathrm{a}, 14 \mathrm{a}$ and 16a}

A colorimetric assay, which relies on detecting the release of CoA from acyl-CoA during the reaction using Ellman's thiol reagent, 5,5'-dithiobis (2-nitrobenzoic acid) (DTNB) was performed. This method was sensitive and reliable for the quantitative detection of CoA. Our method has been slightly modified, according to literature. ${ }^{10}$ 
The Alb29 enzymatic activity was measured by detecting the release of HS-CoA with DTNB. Firstly, the standard curve between the concentration of HS-CoA and the absorbance at $412 \mathrm{~nm}$ was obtained by using a microplate reader (BioTek\&Synergy2, USA). The concentrations of HS-CoA were from $0.244 \mu \mathrm{M}$ to $500 \mu \mathrm{M}$. The HS-CoA samples $(50 \mu \mathrm{L})$ with different concentrations were mixed with an equal volume of 1 $\mathrm{mM}$ DTNB. After incubation for $10 \mathrm{~min}$ at $30{ }^{\circ} \mathrm{C}$, the absorbance at $412 \mathrm{~nm}$ was measured. The concentration of HS-CoA and the absorbance fitted in a good linear line $\left(\mathrm{R}^{2}=1\right.$, Figure $\left.\mathrm{S} 25\right)$.

Subsequently, to measure the kinetic parameters of Alb29 towards the substrates L-Glu, 2a, 3a, 12a, we used the mixture containing $20 \mathrm{mM}$ PBK, with a $\mathrm{pH}$ at 9.0, 100 $\mu \mathrm{M}$ PLP, $0.4 \mu \mathrm{M}$ Alb29 at $30^{\circ} \mathrm{C}$. When ${ }_{\mathrm{L}}$-Glu was used as the substrate, the reaction mixture was supplemented by $100 \mu \mathrm{M} 2 \mathbf{a}$ and varying concentrations of ${ }_{\mathrm{L}}-\mathrm{Glu}(1,3,5$, $8,10,15,20,25$ and $30 \mathrm{mM}$ ). When $2 \mathbf{a}$ or 3a or 12a was used as the substrate, the reaction mixture was supplemented by $20 \mathrm{mM}_{\mathrm{L}}-\mathrm{Glu}$. The concentrations of $2 \mathbf{a}$ ranged from 1, 5, 7, 10, 20, 50 to $100 \mu \mathrm{M}$. The concentrations of $\mathbf{3 a}$ ranged from 5, 10, 25, 50, $75,100,125$ to $150 \mu \mathrm{M}$. The concentrations of $\mathbf{1 2 a}$ ranged from $15,25,50,75,100$, 125, 150 to $200 \mu \mathrm{M}$. These reactions were started by adding Alb29. At different time points $(0,3,6,9,12$ and $15 \mathrm{~min})$, the reaction mixture $(60 \mu \mathrm{L})$ was taken out and quenched by adding an equivalent volume of chloroform. When $4 \mathbf{a}$ was used as the substrate, the standard assay mixture containing $20 \mathrm{mM}$ PBK, pH 9.0, $100 \mu \mathrm{M}$ PLP, $20 \mathrm{mM}_{\mathrm{L}}-\mathrm{Glu}, 5.19 \mu \mathrm{M}$ Alb29 and varying concentrations of $\mathbf{4 a}(10,20,30,50,75$, $100,120,150$ and $200 \mu \mathrm{M}$ ) was used at $30^{\circ} \mathrm{C}$. When $14 \mathbf{a}$ was used as the substrate, the standard assay mixture containing $20 \mathrm{mM}$ PBK, $\mathrm{pH} 9.0,100 \mu \mathrm{M}$ PLP, $20 \mathrm{mM}$ L-Glu, $0.93 \mu \mathrm{M}$ Alb29 and varying concentrations of 14a $(5,10,20,50,75,100,125$, $150,200,250,300$ and $400 \mu \mathrm{M}$ ) was used at $30{ }^{\circ} \mathrm{C}$. When 16a was used as the substrate, the standard assay mixture containing $20 \mathrm{mM}$ PBK, pH 9.0, $100 \mu \mathrm{M}$ PLP, $20 \mathrm{mM}_{\mathrm{L}}-\mathrm{Glu}, 4.63 \mu \mathrm{M}$ Alb29 and varying concentrations of 16a $(10,20,30,40,50$, $75,100,120,150$ and $200 \mu \mathrm{M}$ ) was used at $30^{\circ} \mathrm{C}$. These reactions were started with the addition of Alb29. At different time points at 1, 3, 6, 9, 12 and $15 \mathrm{~min}$, the 
reaction mixture $(60 \mu \mathrm{L})$ was taken out and quenched by adding an equivalent volume of chloroform to remove the protein. Then the supernatant $(50 \mu \mathrm{L})$ was taken out and reacted with $50 \mu \mathrm{L}$ DTNB $(1 \mathrm{mM})$ for the detection of the release of CoA. Reactions were run in triplicate. The increase in absorbance due to the formation of thiophenolate was monitored at $412 \mathrm{~nm}\left(\varepsilon_{412}=13,600 \mathrm{M}^{-1} \mathrm{~cm}^{-1}\right)$ and $30{ }^{\circ} \mathrm{C}$ by the microplate reader (BioTek\&Synergy2, USA). The initial velocity of the reaction was determined by the slope of the linear line plotted by the concentration of CoA corresponding to the absorbance value at different times. The initial velocities measured in this procedure were linear for at least $10 \mathrm{~min}$. Kinetic data were fitted to the Michaelis-Menten rate equation using nonlinear regression data analysis software (GraphPad Prism 7.0).

\subsection{The yields of products $2 \mathrm{~b}, 7 \mathrm{~b}$, and $12 \mathrm{~b}-16 \mathrm{~b}$ in one-pot two-step cascade reaction}

To evaluate the efficiency of the one-pot two-step cascade reaction system, we conducted a quantitative analysis of these products $\mathbf{2 b}, \mathbf{7 b}$, and $\mathbf{1 2 b}-\mathbf{1 6} \mathbf{b}$, obtained from one-pot reactions. We took the response values of the molecular ions in the extracted ion chromatograms (EIC) in UPLC-atmospheric pressure chemical ionization (APCI)-HRMS spectra to calculate the amount. Firstly, different concentrations of the synthetic standards $(100 \mu \mathrm{L})$ were detected to obtain the standard curves to determine the relationship between concentration and the response values of the molecular ions (Figure S26). Subsequently, to measure the yields of products in one-pot reactions, $100 \mu \mathrm{L}$ reaction samples $(20 \mu \mathrm{M}$ Alb29, $20 \mu \mathrm{M} \mathrm{Mgr36}$, $100 \mu \mathrm{M}$ PLP, $10 \mathrm{mM} \mathrm{MgCl} 2,10 \mathrm{mM}$ ATP, $0.1 \%$ Triton X-100, $300 \mu \mathrm{M}$ HS-CoA, 10 $\mathrm{mM}$ L-Glu, $10 \mathrm{mM}$ carboxylic acid and $20 \mathrm{mM}$ PBK buffer $(\mathrm{pH} 8.0)$ at $30{ }^{\circ} \mathrm{C}$ for $4 \mathrm{~h}$ or $10 \mathrm{~h}$ ) were obtained and then terminated by adding an equal volume of $\mathrm{MeOH}$. Protein was removed by centrifugation $(12000 \mathrm{rpm}, 5 \mathrm{~min})$. The supernatant $(80 \mu \mathrm{L})$ was transferred into a sample bottle for APCI-HRMS analysis. Yields were calculated 
by comparing the response values of the molecular ions of the EIC of these products from one-pot reactions. Reactions were run in triplicate.

UPLC-HRMS analysis was performed using a Waters Acquity UPLC system equipped with a Micromass Q-TOF Premier mass spectrometer (Waters MS Technologies, Manchester, UK). Chromatographic separations were performed on a $2.1 \times 100 \mathrm{~mm}(1.7 \mu \mathrm{m})$ Acquity UPLC HSS T3 chromatography column. The column temperature was set at $50{ }^{\circ} \mathrm{C}$. The following gradient was used: $0 \% \mathrm{D}$ from 0 to 0.5 min, $0 \%-10 \% \mathrm{D}$ from 0.5 to $2 \mathrm{~min}, 10 \%-50 \% \mathrm{D}$ from 2.0 to $4.5 \mathrm{~min}, 50 \%-100 \% \mathrm{D}$ from 4.5 to $6.0 \mathrm{~min}, 100 \% \mathrm{D}$ from 6.0 to $7.4 \mathrm{~min}, 0 \% \mathrm{D}$ from $7.4-9.0 \mathrm{~min}$. (solvent $\mathrm{C}$ : water with $0.1 \%$ formic acid; solvent $\mathrm{D}$ : ACN containing $0.1 \%$ formic acid). The flow rate was $0.40 \mathrm{~mL} / \mathrm{min}$. The eluate was directed to the mass spectrometer without splitting. Mass analysis was performed using a Q-TOF mass spectrometer equipped with an APCI source operating in the positive ion modes.

\subsection{The production of $3 c / 3 c^{\prime}, 7 c / 7 c^{\prime}$ and $12 c / 12 c^{\prime}$ in the $\Delta a l b 29$ strain}

To obtain enough $\mathbf{3 b}, \mathbf{7 b}$ and $\mathbf{1 2 b}$, we scaled up the one-pot reaction to $3 \mathrm{~mL}$, terminated by adding an equal volume of chloroform and removed protein by centrifugation (12000 rpm, $5 \mathrm{~min})$. Subsequently, the supernatant $(2.8 \mathrm{~mL})$ was sterilized by filtration and added into the culture of $\Delta a l b 29$ strain, which had been prepared at $30{ }^{\circ} \mathrm{C}$ before $2 \mathrm{~d}$, respectively. The broth were extracted and analyzed by HPLC after continuously culturing for $5 \mathrm{~d}$. The methods of extraction and analysis were the same as the analytical method in 2.4. In addition, to further seperate the stereoisomers of $\mathbf{3 c} / \mathbf{3} \mathbf{c}^{\prime}, \mathbf{7} \mathbf{c} / \mathbf{7} \mathbf{c}^{\prime}$ and $\mathbf{1 2} \mathbf{c} / \mathbf{1 2} \mathbf{c}^{\prime}$, we tried UPLC-HRMS, supercritical fluid chromatography (SFC) and SFC-MS/MS .

UPLC-HRMS analysis was performed using a Waters Acquity UPLC system equipped with a Micromass Q-TOF Premier mass spectrometer (Waters MS Technologies, Manchester, UK). Chromatographic separations were performed on a $2.1 \times 100 \mathrm{~mm}(1.7 \mu \mathrm{m})$ Acquity BEH C18 chromatography column. The column 
temperature was set at $45{ }^{\circ} \mathrm{C}$. The gradient elution program started from $5 \% \mathrm{D}$, changed to $30 \% \mathrm{D}$ within $2.5 \mathrm{~min}$, to $60 \% \mathrm{D}$ within $5 \mathrm{~min}$, to $100 \% \mathrm{D}$ within $4 \mathrm{~min}$, and was finally held at $100 \% \mathrm{D}$ for 2 min (solvent $\mathrm{C}$ : water of $0.1 \%$ formic acid; solvent D: ACN containing $0.1 \%$ formic acid). The flow rate was $0.40 \mathrm{~mL} / \mathrm{min}$. The eluate was directed to the mass spectrometer without splitting. Mass analysis was performed using a Q-TOF mass spectrometer equipped with an ESI source operating in the negative ion modes.

SFC analysis was performed using a Waters Acquity UPLC Xevo G2-XS system (Waters Technologies, Manchester, UK). Chromatographic separations were performed on a $3.0 \times 150 \mathrm{~mm}(2.5 \mu \mathrm{m})$ Acquity CEL1 chiral chromatography column. The column temperature was set at $45{ }^{\circ} \mathrm{C}$. The gradient elution program started from $10 \% \mathrm{G}$, changed to $30 \% \mathrm{G}$ within $8 \mathrm{~min}$, maintained $30 \% \mathrm{G}$ to $15 \mathrm{~min}$, changed to $10 \% \mathrm{G}$ within $15.1 \mathrm{~min}$, and was finally held at $10 \% \mathrm{G}$ for $5 \mathrm{~min}$ (solvent $\mathrm{F}$ : carbon dioxide; solvent G: $\mathrm{MeOH}$ ). The flow rate was $1.5 \mathrm{~mL} / \mathrm{min}$. The pressure was set at 2000 psi.

General SFC-MS/MS analysis was conducted by combining the SFC analysis and Q-TOF mass spectrometer equipped with an ESI source operating in the negative ion modes. The eluate of SFC was directed to the mass spectrometer without splitting. MS/MS analysis using two collision energy ramp, the upper limit of collision energy ramp was $40 \mathrm{eV}$, the lower limit of collision energy ramp is $10 \mathrm{eV}$. HRMS analysis on full scan mass spectrometry was used the following parameters: MS mode, $\mathrm{m} / \mathrm{z}$ 50-600, scan time $0.1 \mathrm{~s}$, desolvation temperature $500{ }^{\circ} \mathrm{C}$, source temperature $120{ }^{\circ} \mathrm{C}$, desolvation gas $1000 \mathrm{~L} / \mathrm{h}$, cone gas $50 \mathrm{~L} / \mathrm{h}$, Capillary voltage $2 \mathrm{kV}$. Processing of the raw data was performed using the Masslynx v4.1. SFC-MS/MS analysis of 7c/7 $\mathbf{c}^{\prime}$ was conducted by combining the SFC analysis and Vion IMS Q-TOF mass spectrometer equipped with an ESI source operating in the negative ion modes. The eluate of SFC was directed to the mass spectrometer without splitting. MS/MS analysis using two collision energy ramp, the upper limit of collision energy ramp was $45 \mathrm{eV}$, the lower limit of collision energy ramp is $4 \mathrm{eV}$. HRMS analysis on full scan mass spectrometry 
was used the following parameters: MS mode, $m / z$ 50-1000, scan time $0.2 \mathrm{~s}$, desolvation temperature $450{ }^{\circ} \mathrm{C}$, source temperature $115^{\circ} \mathrm{C}$, desolvation gas $900 \mathrm{~L} / \mathrm{h}$, cone gas $50 \mathrm{~L} / \mathrm{h}$, Capillary voltage $2.5 \mathrm{kV}$. Processing of the raw data was performed using the UNIFI 1.8.1 (Waters). 


\section{Supporting figures}
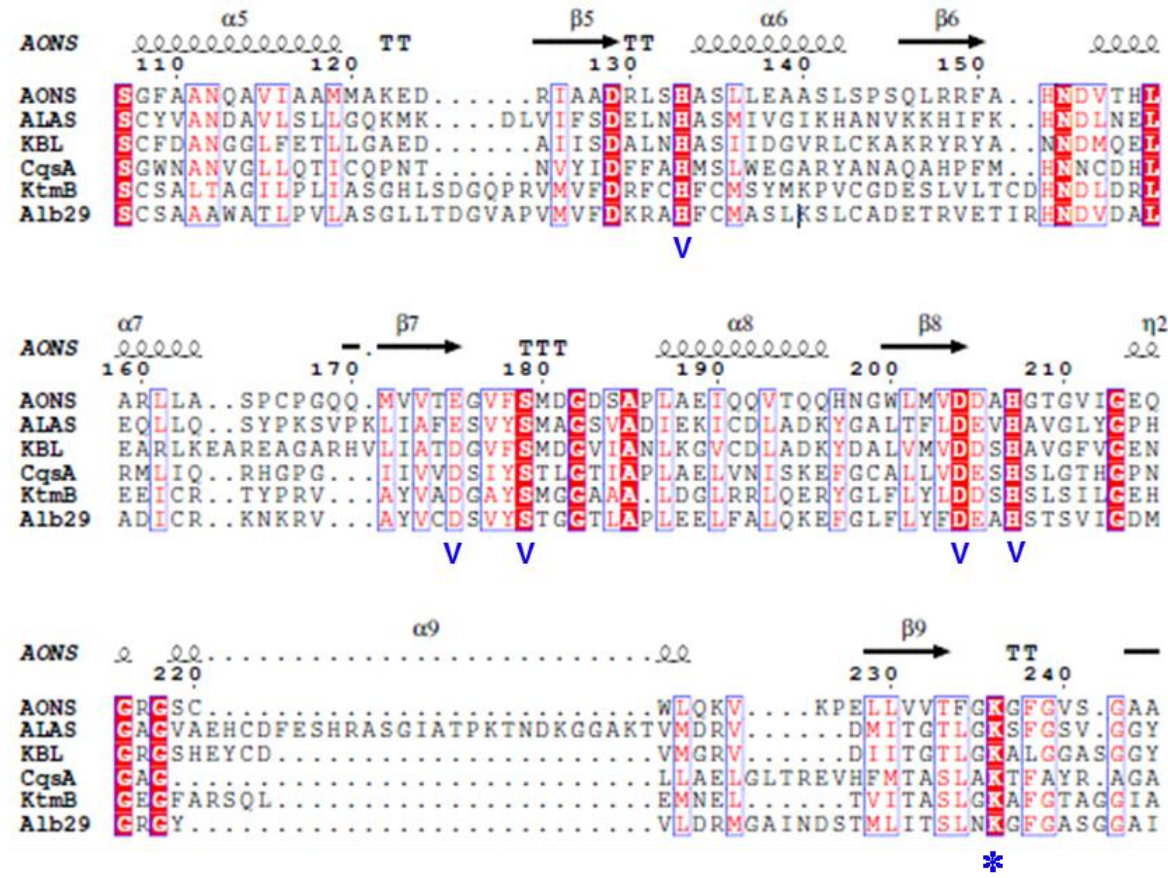

\section{Figure S1. Multiple sequence alignment of Alb29}

The catalytically important residues were marked with a blue V, whereas Lys236, which formed a Schiff base with the PLP cofactor, was marked with a blue star. 
A

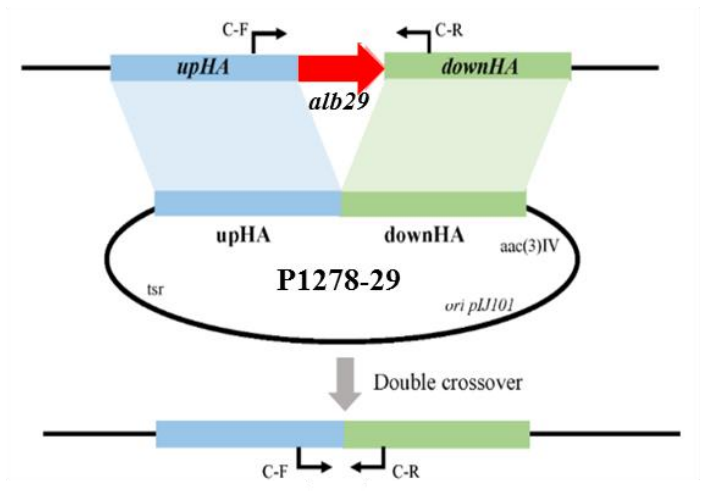

B

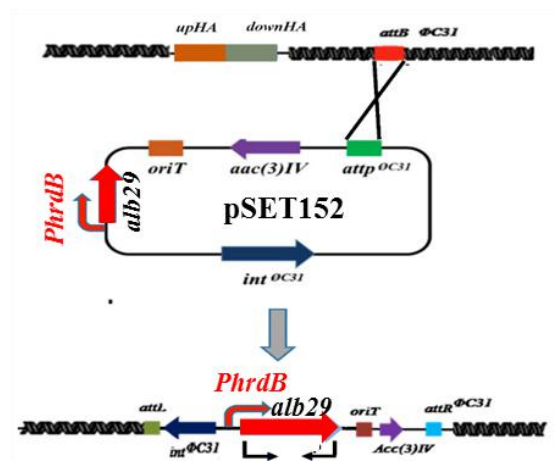

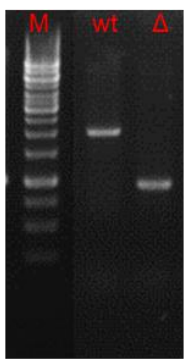

alb29T-F/R
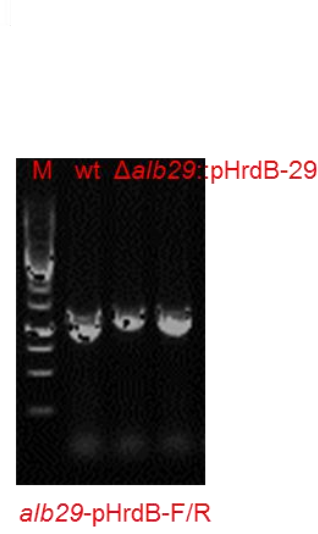

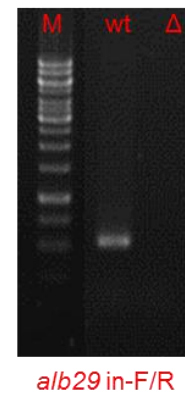

Figure S2. Construction of the $\Delta$ alb29 mutant and alb29 complementation strain

(A) In-frame deletion of alb29 gene. PCR confirmation of the $\triangle a l b 29$ with the wild type $S$. albogriseolus MGR072 as the positive control. (B) The complementation of alb29 using the pHrdB vector. PCR confirmation of the complementation strain Salb29::pHrdB-29 with the wild type S. albogriseolus MGR072 as the positive control. 
A

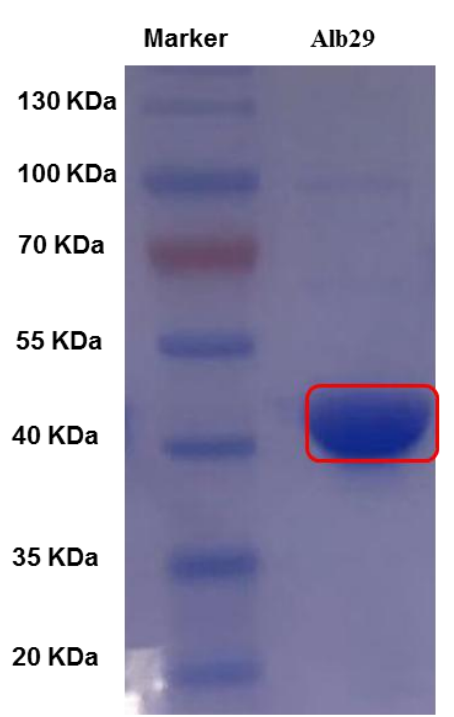

B

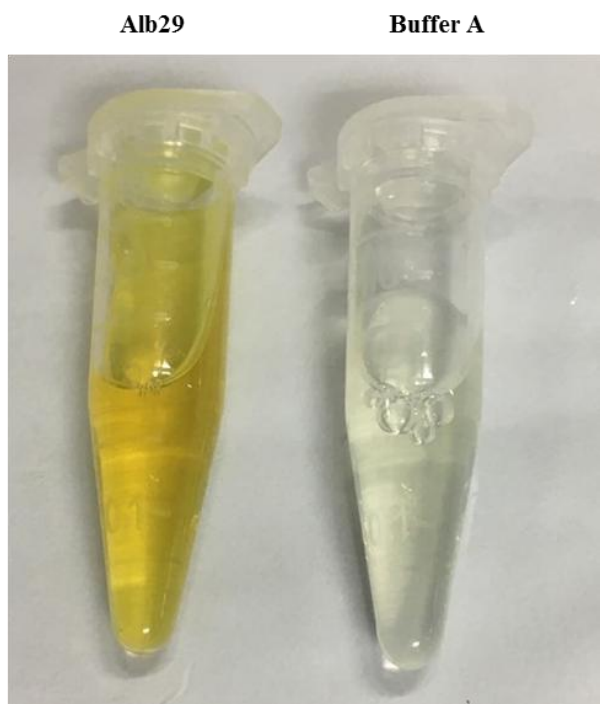

\section{Figure S3. Purification of $\mathrm{N}$-His 6 tagged Alb29}

(A) The SDS-PAGE analysis of Alb29. Purified Alb29; Marker: Page Ruler Prestained Protein Ladder (Thermo Scientific, \#26616). (B) Alb29 showed a yellow color, which was consistent with typical PLP-containing proteins. 

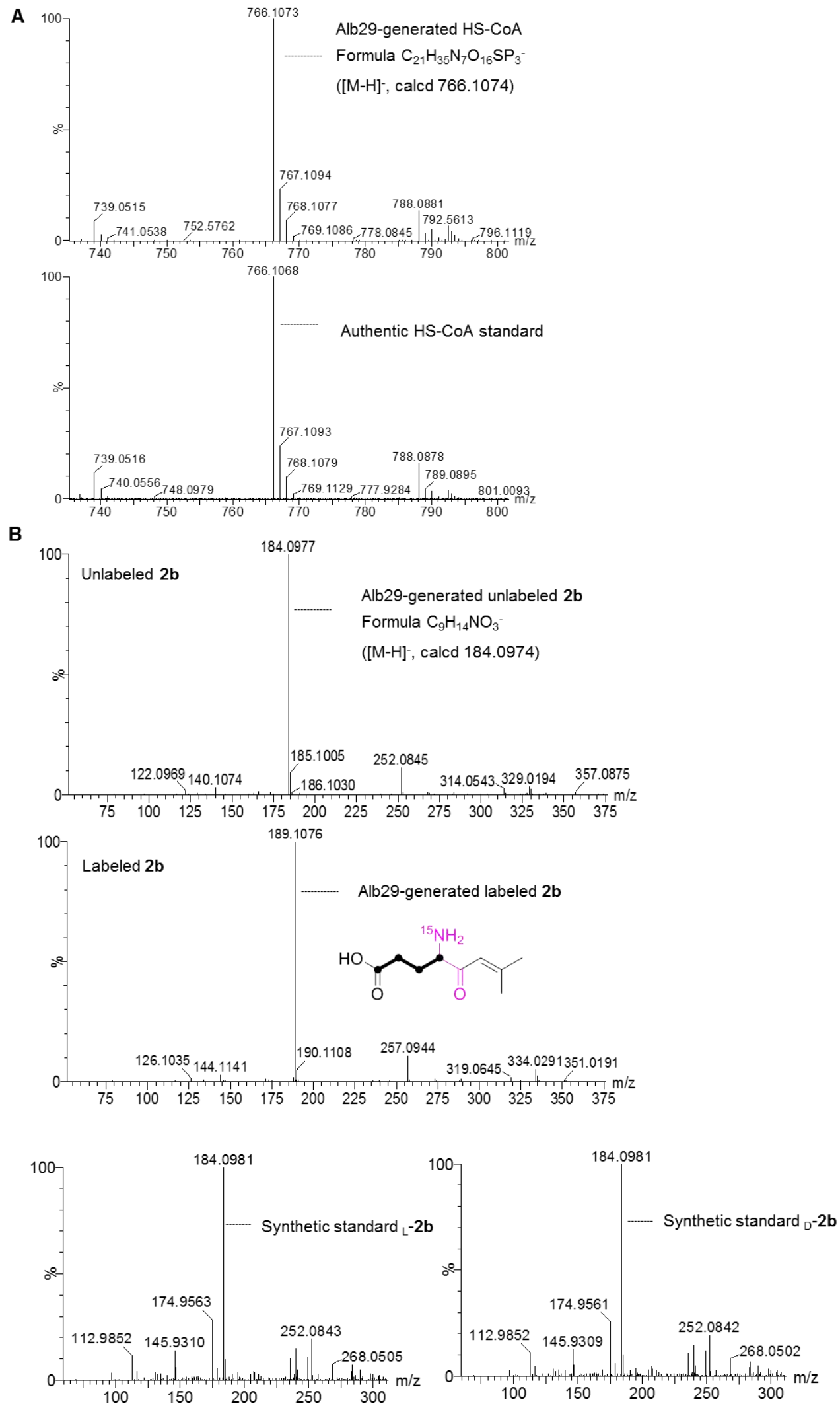

Figure S4. HRMS (ESI-) spectra of Alb29-generated products

(A) Product HS-CoA. (B) Product 2b. 
A

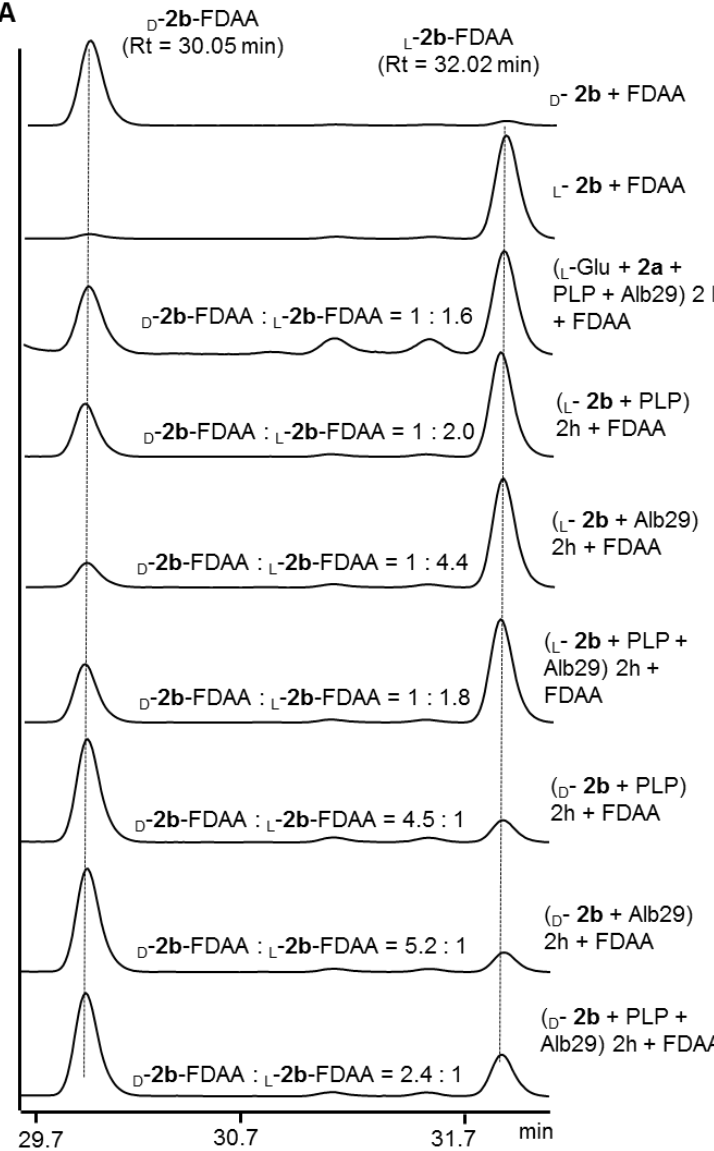

B
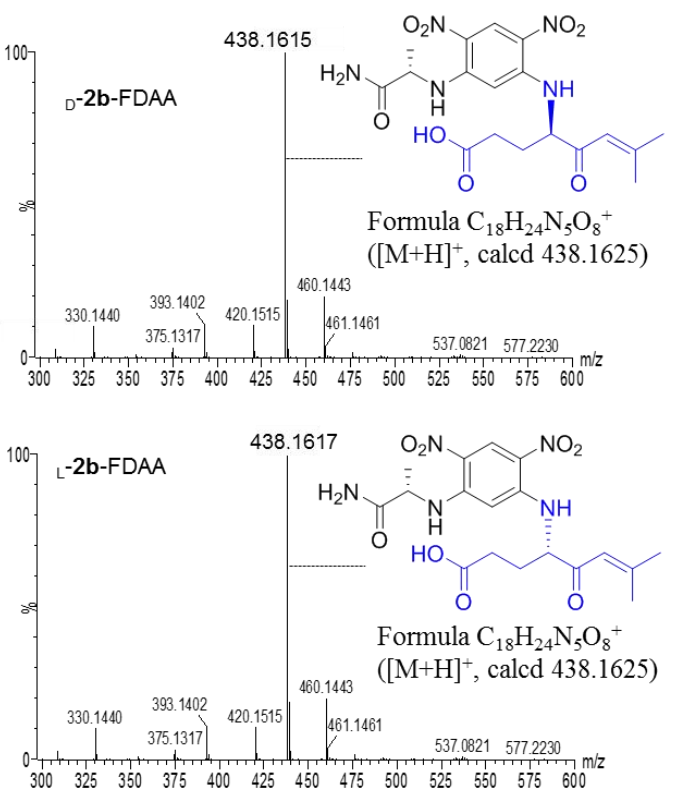

\section{Figure S5. The FDAA derivatives of $2 \mathrm{~b}$ under different reaction conditions}

(A) HPLC analysis of $\mathbf{2 b}$ derivatives (monitored at $325 \mathrm{~nm}$ ). Firstly, the reaction mixture $(100 \mu \mathrm{L})$ was incubated for $2 \mathrm{~h}$ to produce $\mathbf{2 b}$ in $20 \mathrm{mM}$ PBK buffer, $\mathrm{pH}$ 8.0, at $30{ }^{\circ} \mathrm{C}$. Then, the product $\mathbf{2 b}$ was derivatized with FDAA and analyzed by HPLC. The ratio of two isomers was calculated based on the peak area by HPLC. (B) HRMS $\left(\mathrm{ESI}^{+}\right)$spectra of ${ }_{\mathrm{D}}-\mathbf{2 b}-\mathrm{FDAA}$ and $\mathrm{L}_{\mathrm{-}} \mathbf{2 b}$-FDAA derivatives.

RT: Retention time in HPLC analysis. 
A

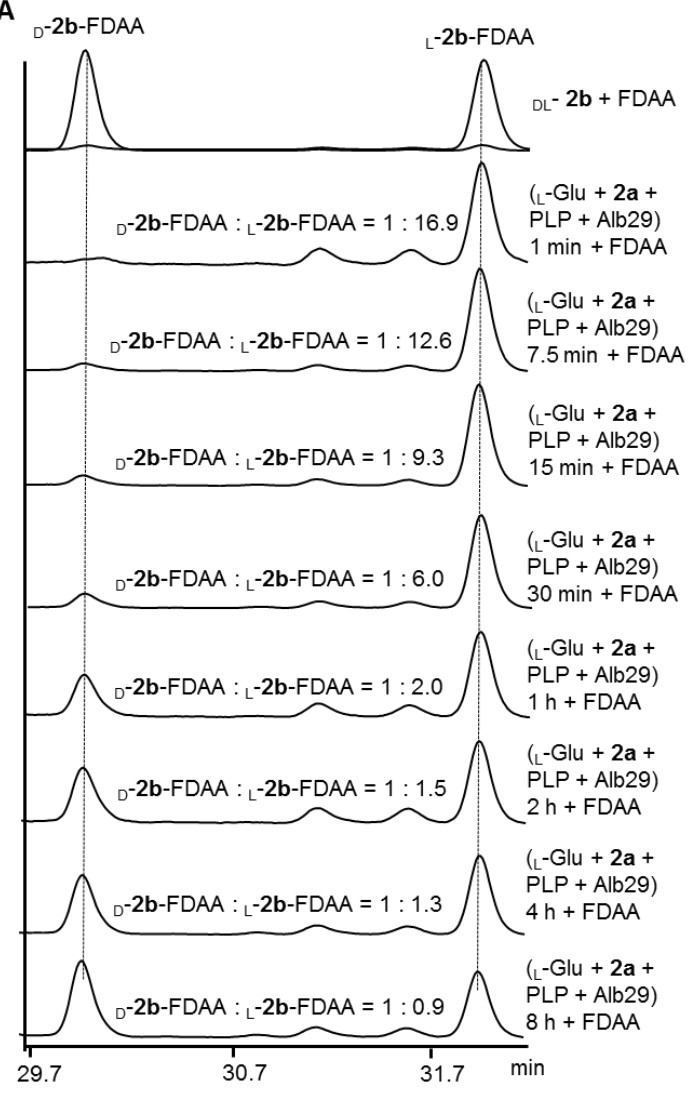

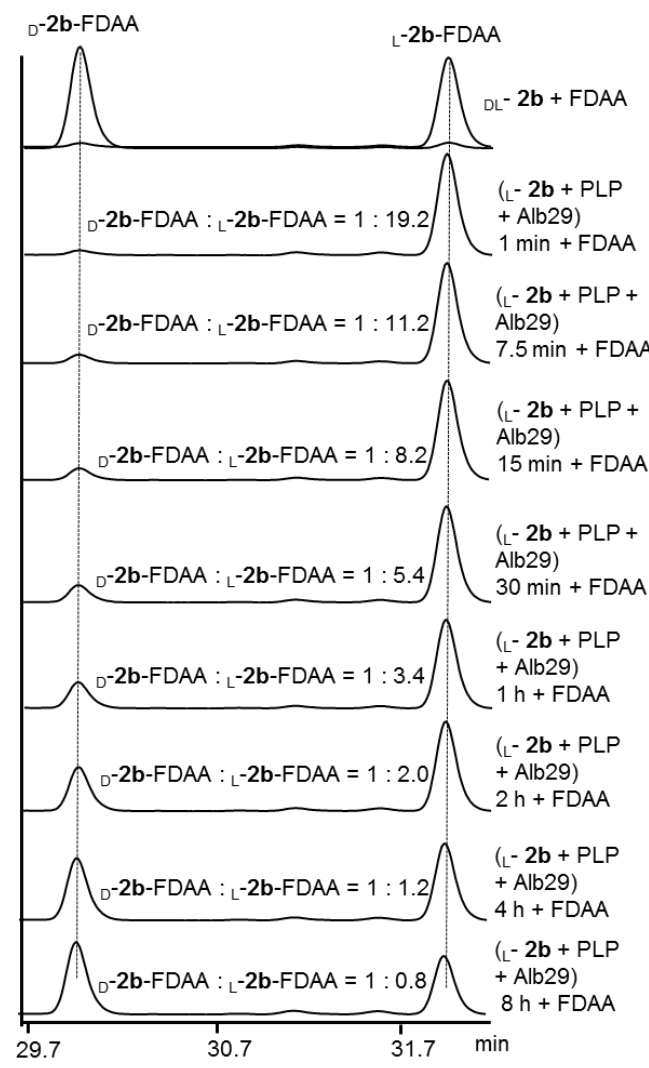

Figure S6. Time-course analysis of enzymatic products taking ${ }_{\text {L-2b-FDAA and }}$ D-2b-FDAA as authentic standards

(A) HPLC analysis of the FDAA derivatives of $\mathbf{2 b}$ produced by Alb29 enzymatic reaction (monitored at $325 \mathrm{~nm}$ ). Firstly, the reaction $(500 \mu \mathrm{L})$, containing $20 \mathrm{mM}$

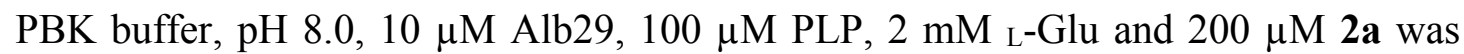
started in a $2.0 \mathrm{~mL}$ tube at $30{ }^{\circ} \mathrm{C}$. The reaction was monitored at a series of time points ( $1 \mathrm{~min}, 7.5 \mathrm{~min}, 15 \mathrm{~min}, 30 \mathrm{~min}, 1 \mathrm{~h}, 2 \mathrm{~h}, 4 \mathrm{~h}$ and $8 \mathrm{~h}$ ). The ratio was calculated based on the peak area of FDAA derivatives. (B) HPLC analysis of the derivatives of synthetic ${ }_{L}-\mathbf{2 b}$ incubated with the enzymatic system (monitored at $325 \mathrm{~nm}$ ). The reaction system containing $20 \mathrm{mM}$ PBK buffer, $\mathrm{pH}$ 8.0, $10 \mu \mathrm{M}$ Alb29, $100 \mu \mathrm{M}$ PLP, and $200 \mu \mathrm{M}_{\mathrm{L}}-\mathbf{2 b}$ was started in a $2.0 \mathrm{~mL}$ tube at $30{ }^{\circ} \mathrm{C}$. The reaction was monitored at a series of time points as mentioned above. 
A

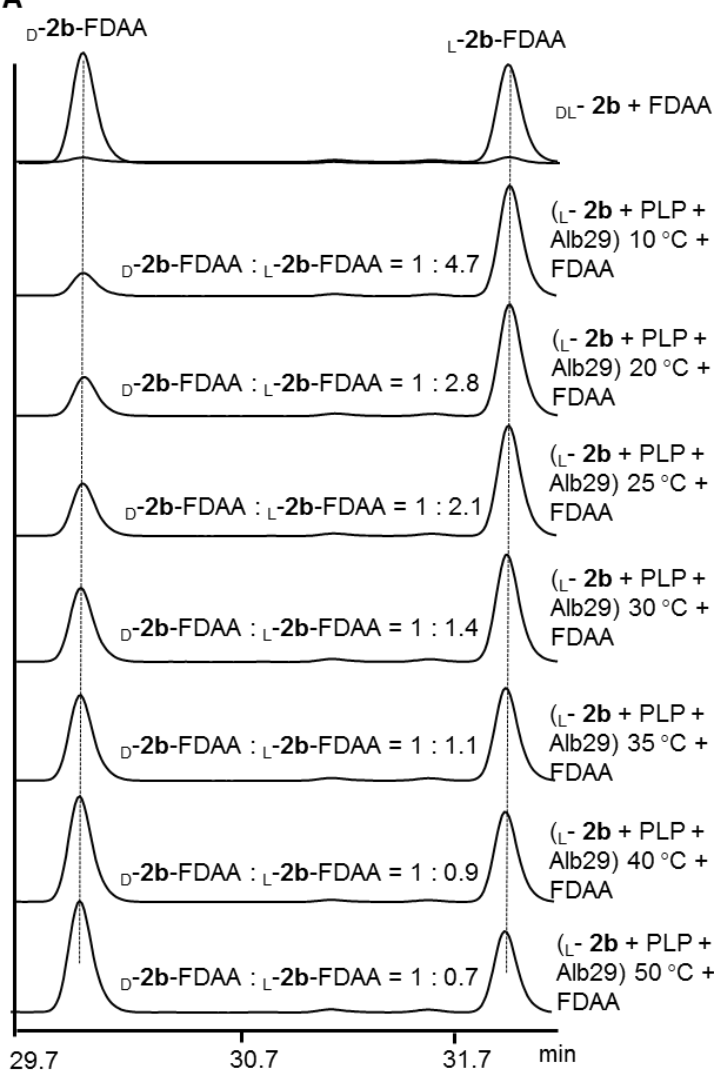

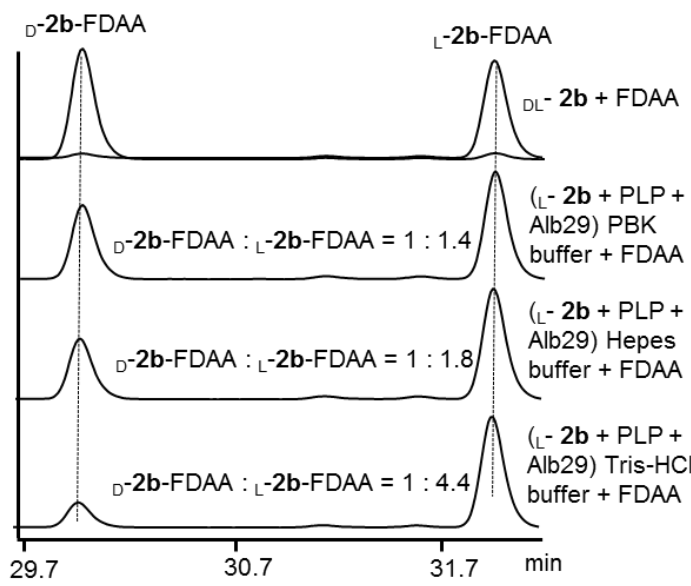

\section{Figure S7. Effects of temperature and buffer on the racemization of ${ }_{L}-2 b$}

(A) Effect of temperature on the racemization of $\mathrm{L}_{\mathrm{L}} \mathbf{- 2 \mathbf { b }}$ (monitored at $325 \mathrm{~nm}$ ). The 100 $\mu \mathrm{L}$ mixture $(20 \mathrm{mM}$ PBK buffer, $\mathrm{pH} 8.0,10 \mu \mathrm{M}$ Alb29, $100 \mu \mathrm{M}$ PLP and $200 \mu \mathrm{m}$ synthetic $\left.{ }_{\mathrm{L}}-\mathbf{2 b}\right)$ was incubated for $2 \mathrm{~h}$ at different temperatures ranging from 10 to 50 ${ }^{\circ} \mathrm{C}$. Then, the mixture was derivatized with FDAA. The ratio was calculated based on the peak area. (B) Effect of buffer on the racemization of ${ }_{L}-\mathbf{2 b}$ (monitored at $325 \mathrm{~nm}$ ). The $100 \mu \mathrm{L}$ mixture containing $10 \mu \mathrm{M}$ Alb29, $100 \mu \mathrm{M}$ PLP and $200 \mu \mathrm{M}$ synthetic

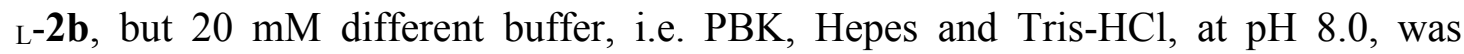
incubated for $2 \mathrm{~h}$ at $30{ }^{\circ} \mathrm{C}$. Then, the mixture was derivatized with FDAA and analyzed by HPLC. The ratio was calculated based on the peak area. 

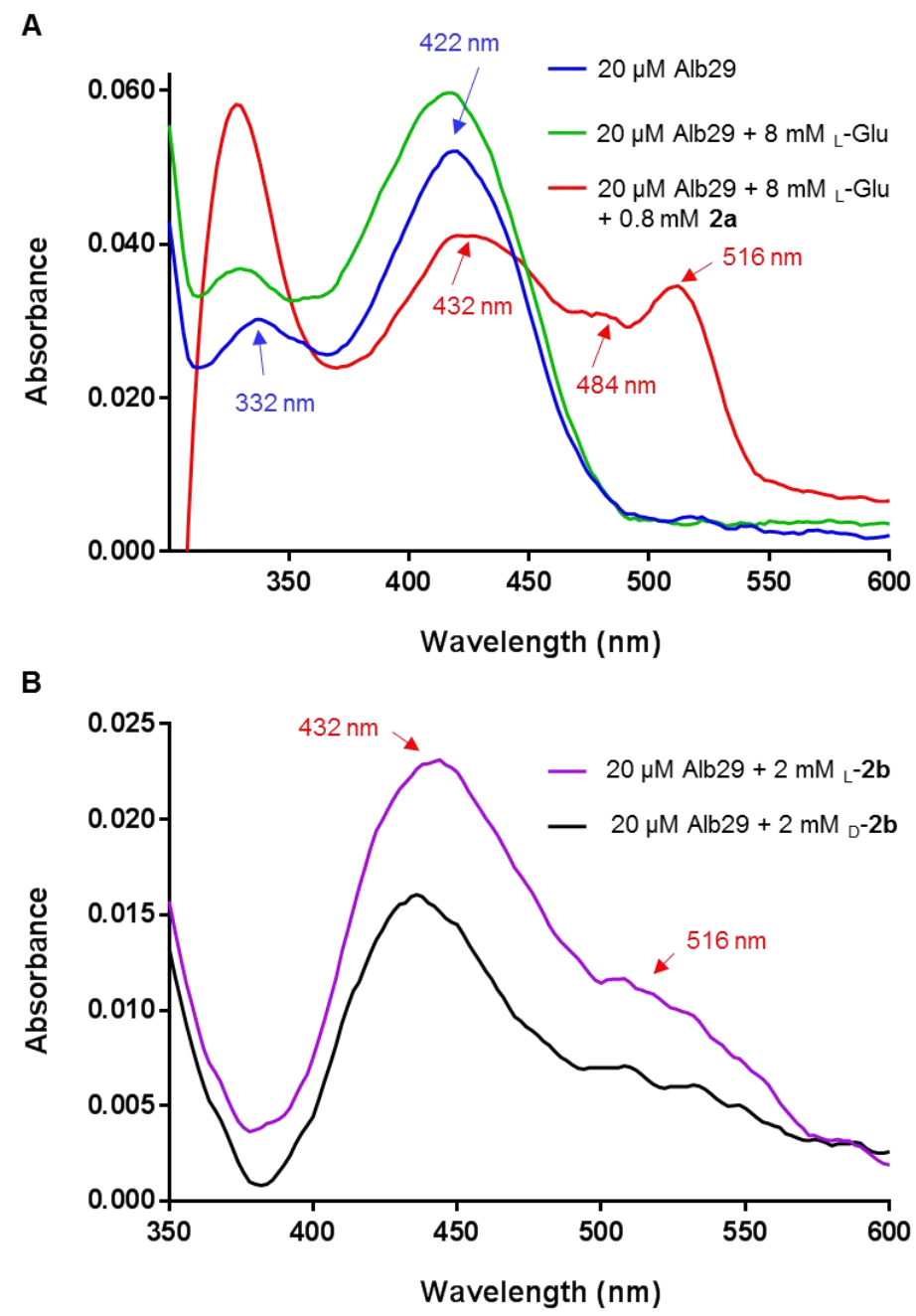

Figure S8. The UV-vis spectra of Alb29

(A) $20 \mu \mathrm{M}$ Alb29 (blue line); Alb29 with $8 \mathrm{mM}_{\mathrm{L}}$-Glu (green line); Alb29 incubated for $2 \mathrm{~h}$ with $8 \mathrm{mM}_{\mathrm{L}}$-Glu and $0.8 \mathrm{mM} \mathbf{2 a}$ (red line). (B) $20 \mu \mathrm{M}$ Alb29 with $2 \mathrm{mM}_{\mathrm{L}}-\mathbf{2 b}$ (purple line); $20 \mu \mathrm{M}$ Alb29 with $2 \mathrm{mM}_{\mathrm{D}}-\mathbf{2 b}$ (black line). 


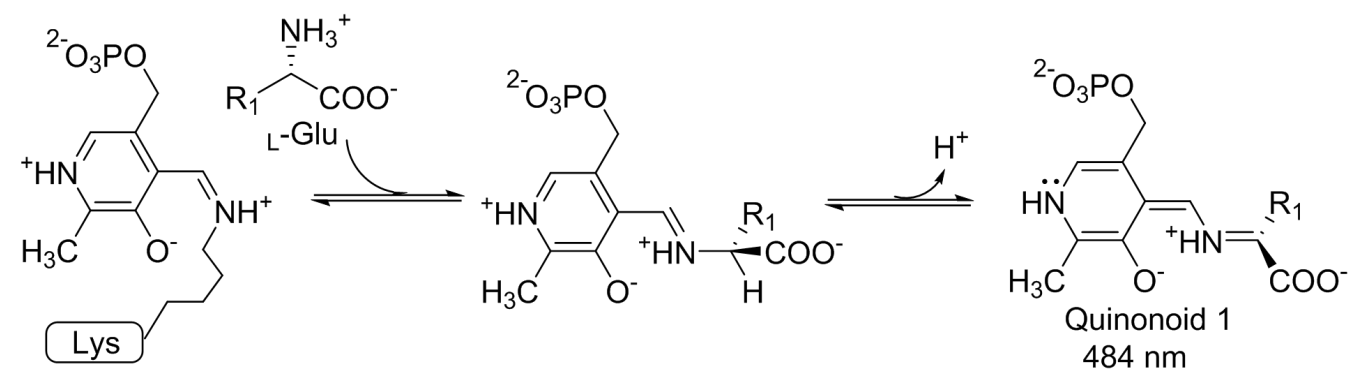

Internal aldimine (Alb29-PLP)<smiles>[R]C(N)C(=O)/C=C(/C)CCCCC</smiles>

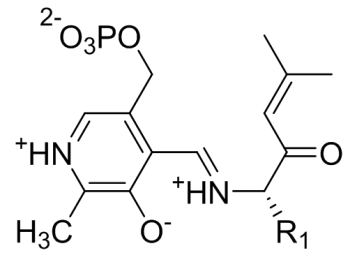

External aldimine 2 $432 \mathrm{~nm}$
External aldimine 1 (Alb29-Glu)

$422 \mathrm{~nm}$

$$
84 \mathrm{~nm}
$$

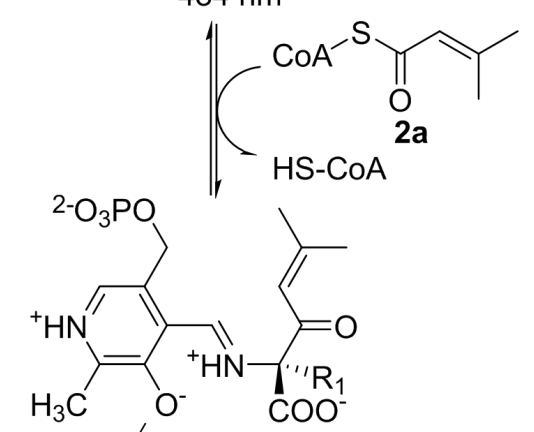

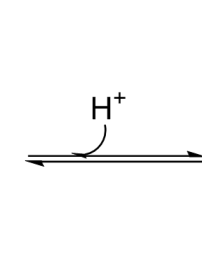<smiles>[R6]OCC1=CNC(C)=C([O-])C1=CN=C([R7])C(=O)C=C(C)C</smiles>

Quinonoid 2 $516 \mathrm{~nm}$

Figure S9. The proposed mechanism of Claisen-like condensation catalyzed by Alb2911 


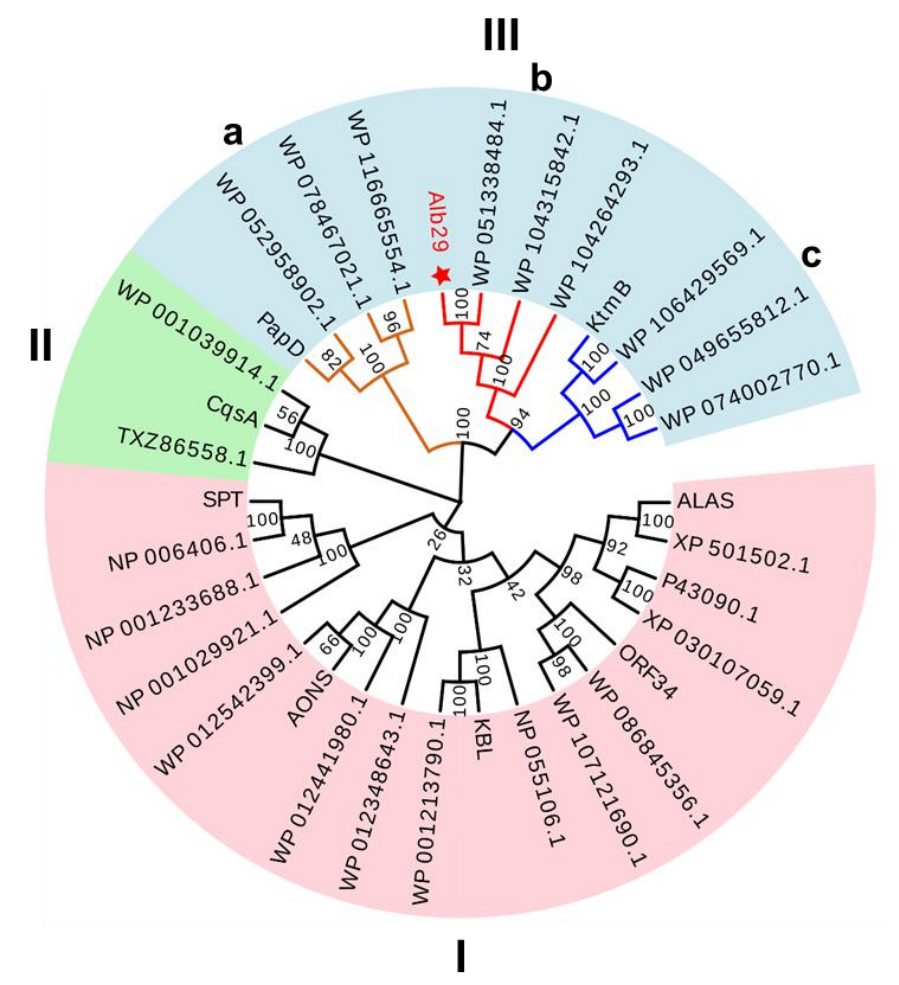

\section{Figure S10. Phylogenetic analysis of Alb29}

The evolutionary history was inferred by using the Maximum Likelihood method based on the JTT matrix-based model. ${ }^{7}$ The tree with the highest log likelihood $(-14321.6599)$ is shown. The percentage of trees in which the associated taxa clustered together is shown next to the branches. Initial tree(s) for the heuristic search were obtained automatically by applying Neighbor-Join and BioNJ algorithms to a matrix of pairwise distances estimated using a JTT model, and then selecting the topology with superior log likelihood value. The tree is drawn to scale, with branch lengths measured in the number of substitutions per site. The analysis involved 33 amino acid sequences. All positions containing gaps and missing data were eliminated. There were a total of 358 positions in the final dataset. Evolutionary analyses were conducted in MEGA7. ${ }^{12}$

The phylogenetic tree of Alb29 (marked by a solid red star) and the reported AOSs as stand-alone enzymes, as well as NCBI BLASTP hits of these proteins. The tree was divided into three distinct clades: clade I, the AOSs that use glycine, alanine or serine as substrates, and their homologs; clade II, the AOSs which involve in the biosynthesis of signaling molecules using unnatural amino acids, and their homologs; clade III, Alb29 and the AOSs that use aromatic amino acids, and their homologs. Alb29 and some homologs formed a unique subclade III-b. 


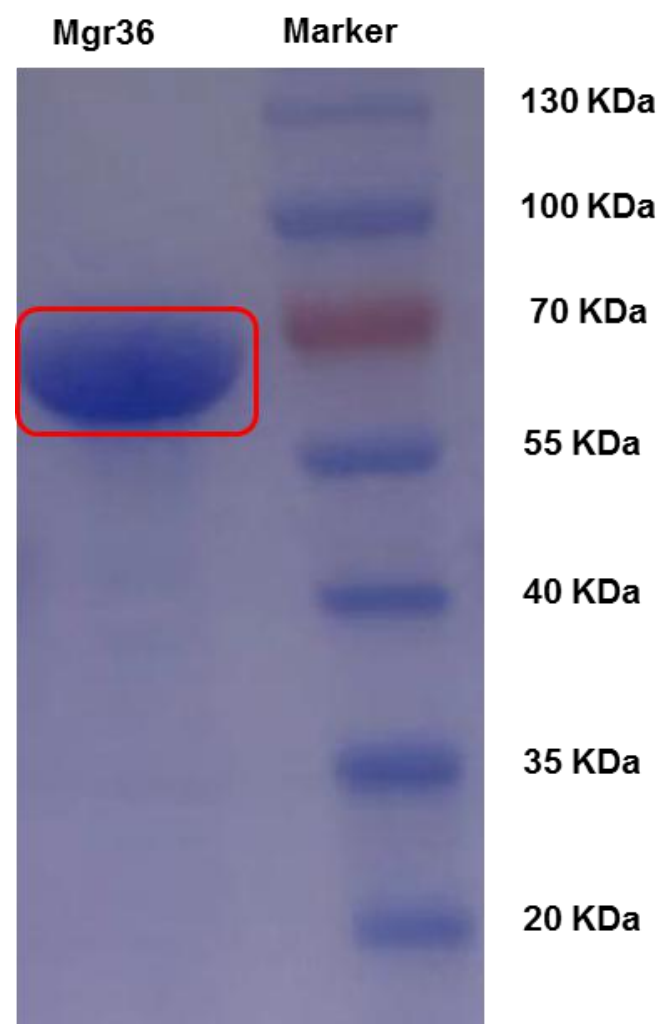

Figure S11. SDS-PAGE analysis of purified $\mathrm{N}$-His 6 tagged Mgr36

Purified Mgr36; Marker: Page Ruler Prestained Protein Ladder (Thermo Scientific, \#26616). 


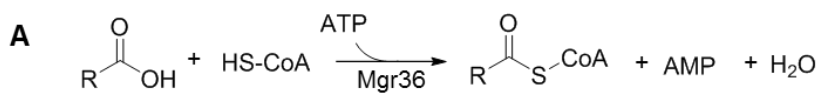

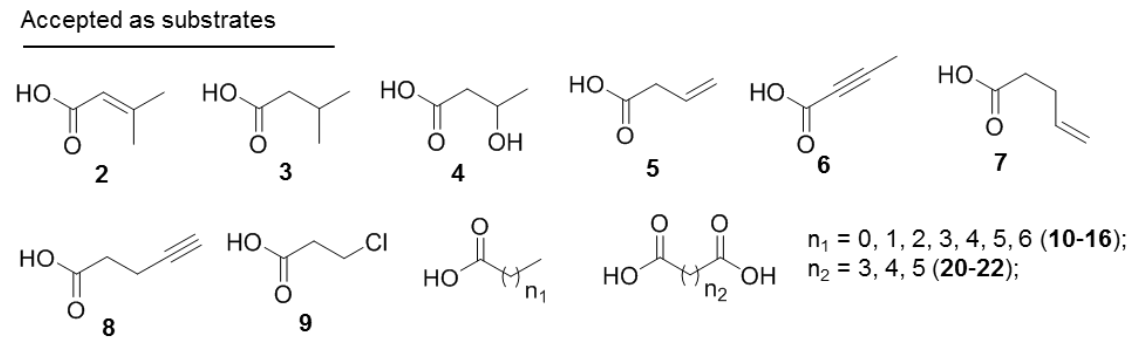

B

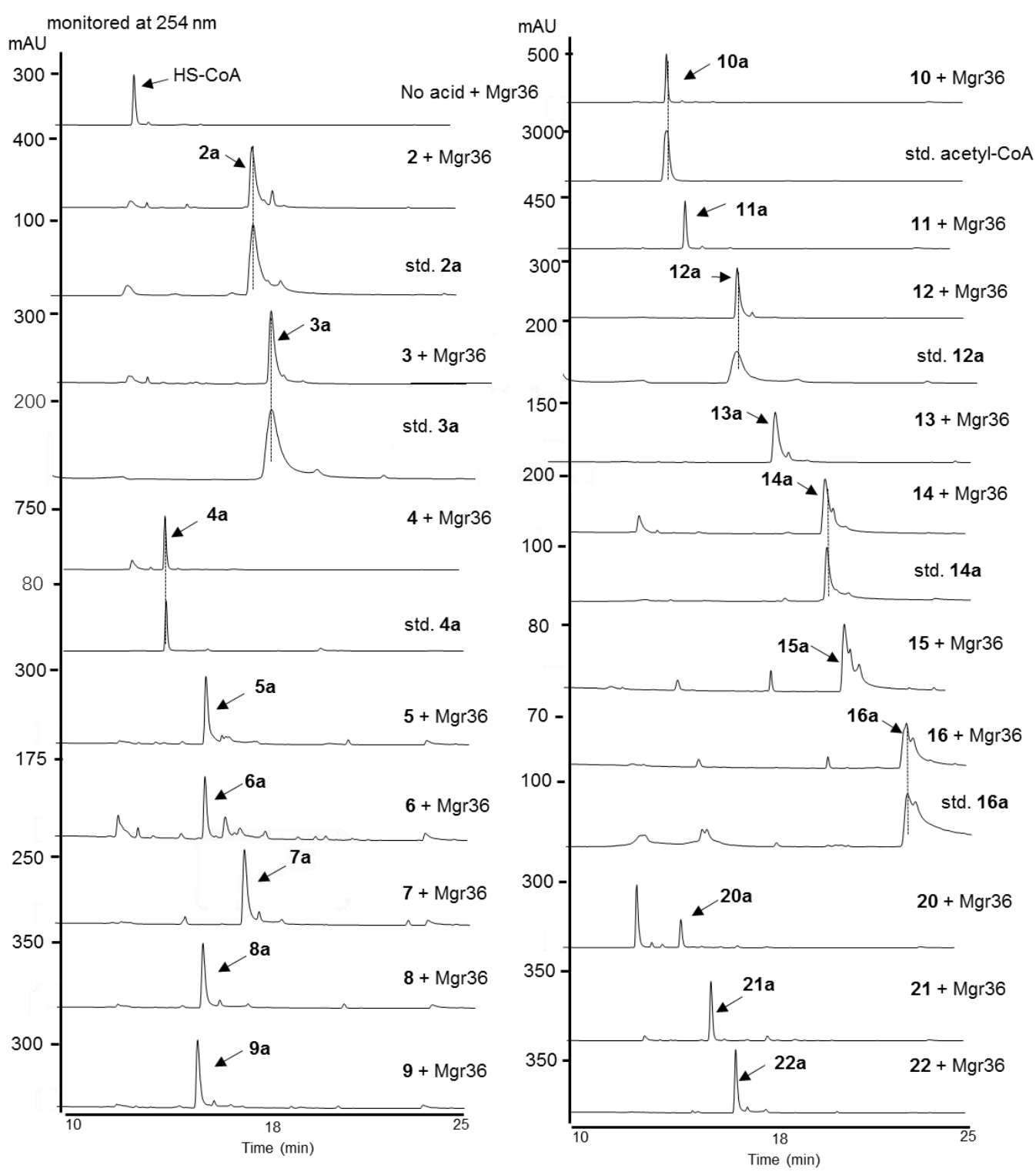

Figure S12. In vitro biochemical assays of Mgr36 with different substrates

(A) Structures of the accepted substrates. (B) HPLC profiles (monitored at $254 \mathrm{~nm}$ ) of Mgr36 with different substrates. The products 2a, 3a, 4a, 10a, 12a, 14a and 16a produced by Mgr36 enzymatic reactions were confirmed by comparison with the authentic standards which were commercial available from Sigma-Aldrich company. 

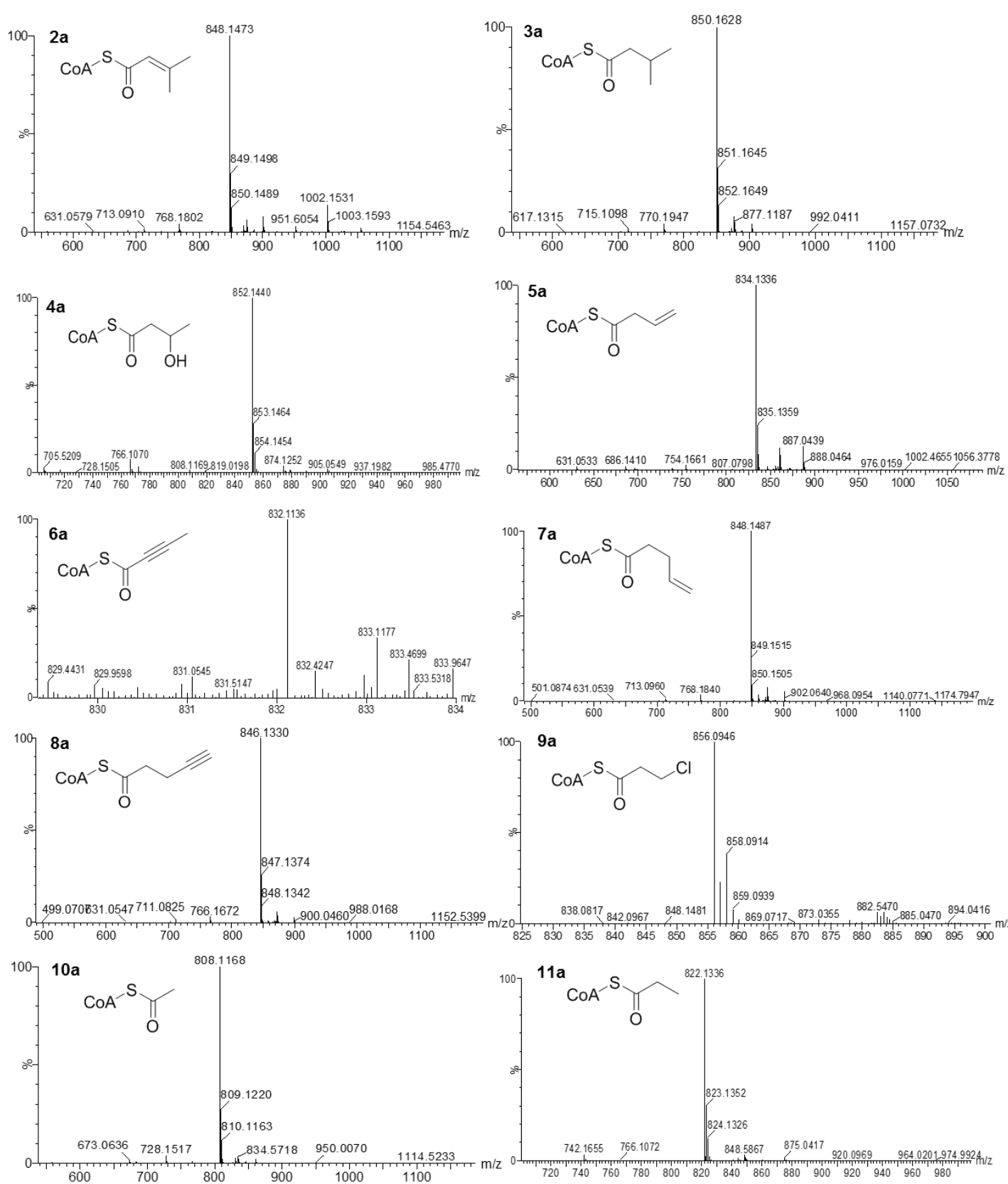

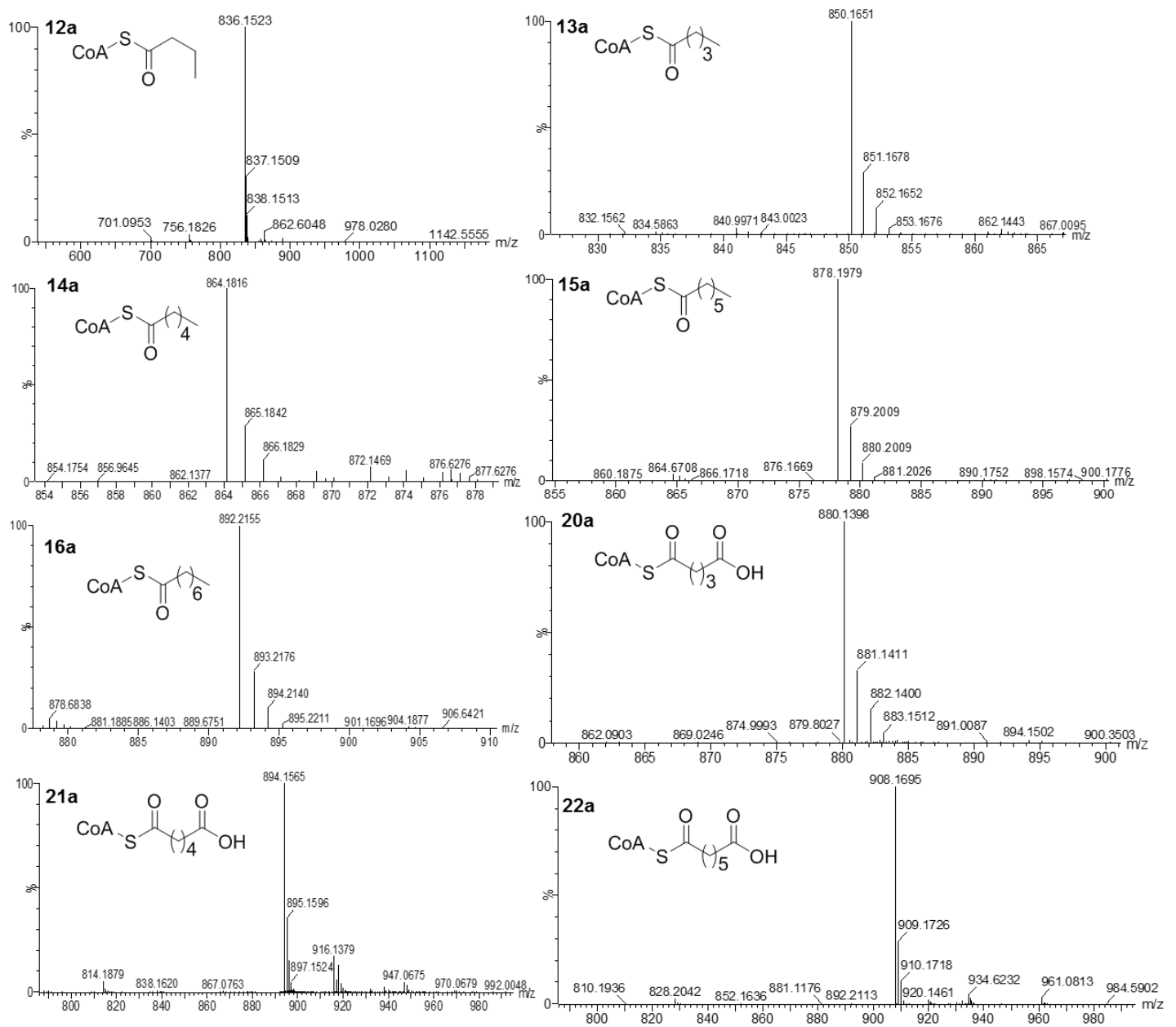

Figure S13. HRMS (ESI') analysis of the Mgr36-generated acyl-CoA products (2a-16a, 20a-22a) 

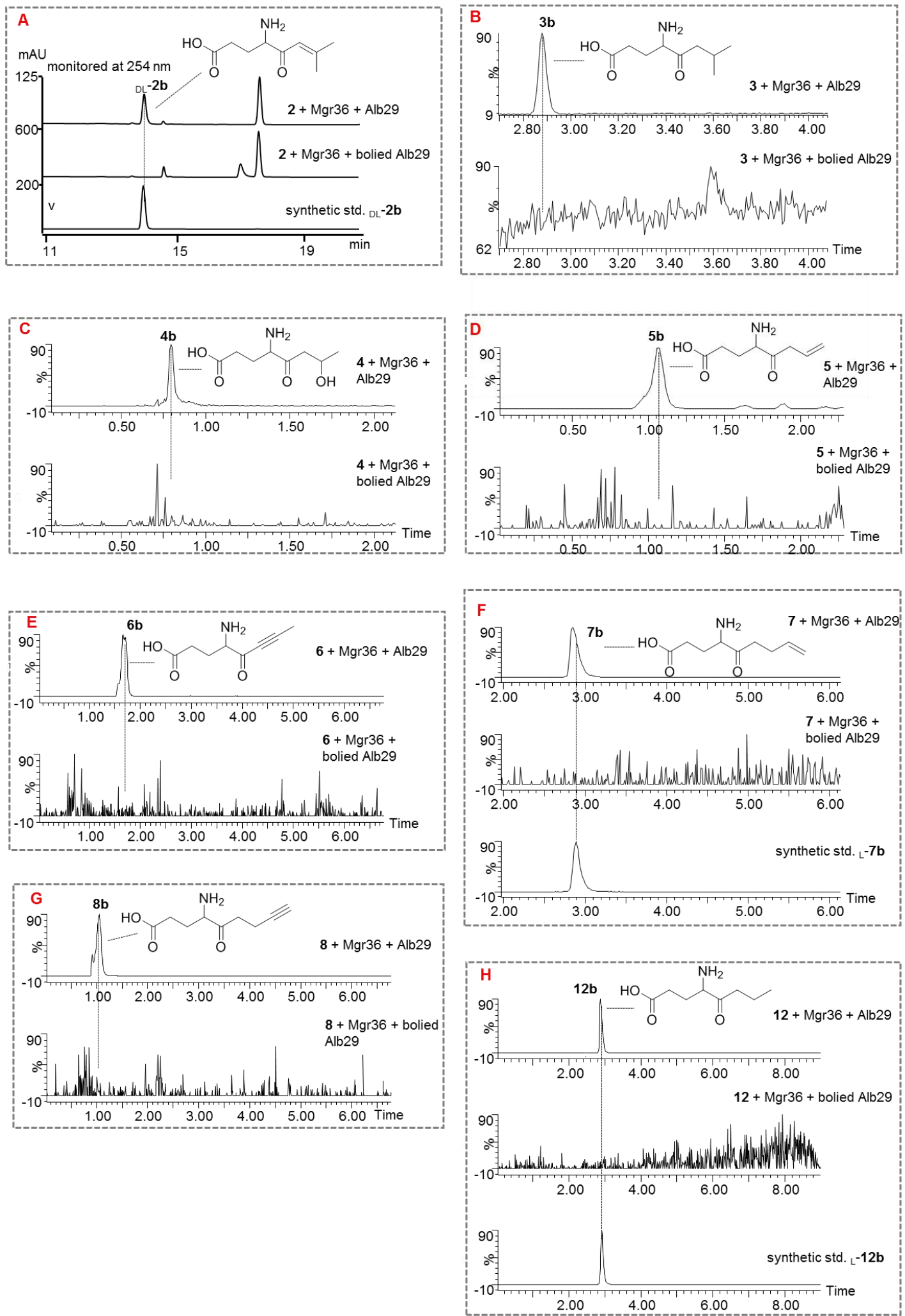

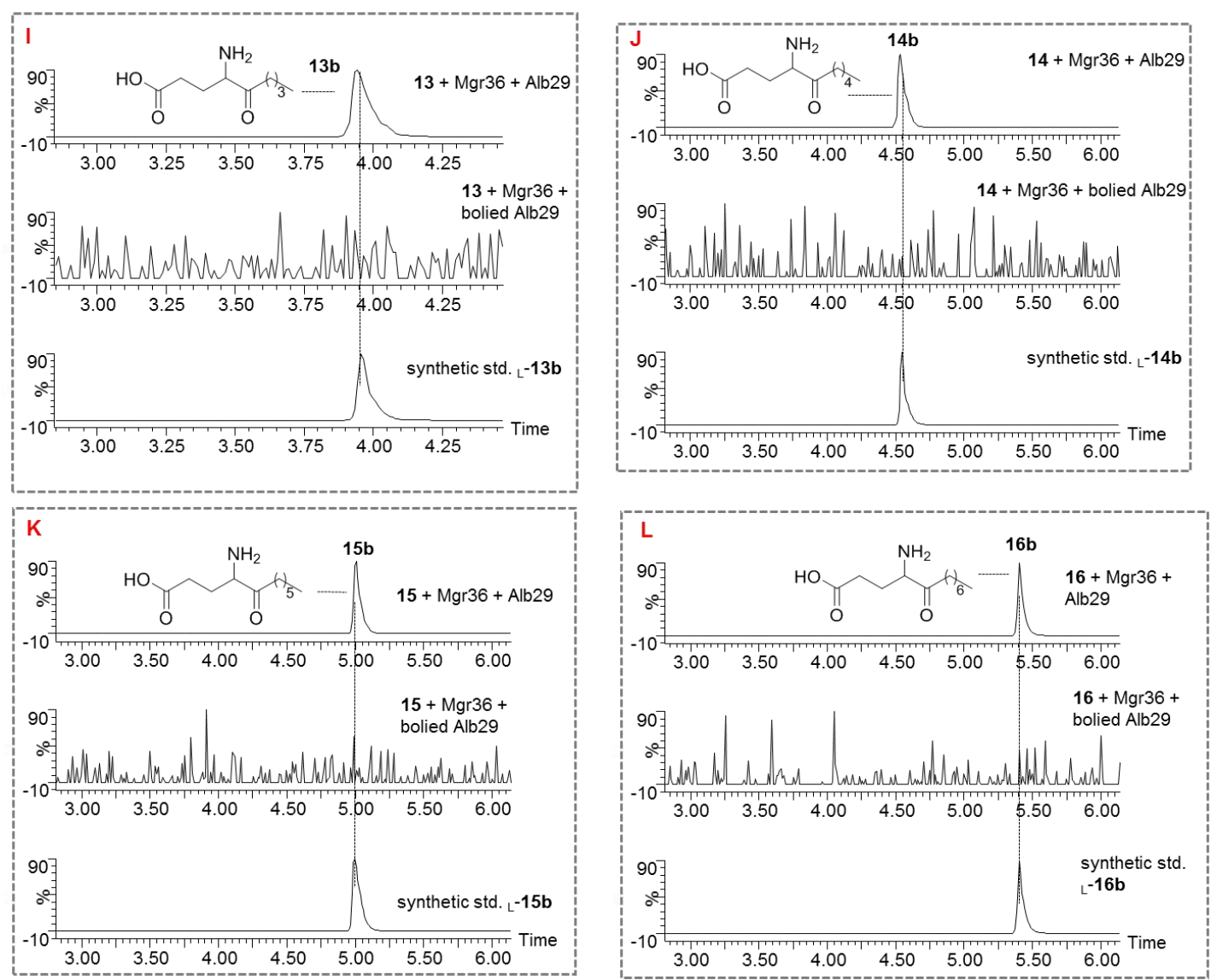

Figure S14. UPLC-MS analysis of the $\alpha$-ketoamine products from one-pot reaction

Using 2 (A), 3 (B), 4 (C), 5 (D), 6 (E), 7 (F), 8 (G), 12 (H), 13 (I), 14 (J), 15 (K) and 16 (L) as substrates, respectively.

The products $\mathbf{2} \mathbf{b}$ formed in one-pot reaction were confirmed by comparison with the synthetic standards by HPLC. The other products $\mathbf{7 b}$ and $\mathbf{1 2 b - 1 6 b}$ formed in one-pot reaction were confirmed by comparing the EIC of UPLC-HRMS with the synthetic standards. The other products $\mathbf{3 b}-\mathbf{6 b}$ and $\mathbf{8 b}$ formed in one-pot reaction were confirmed by the UPLC-HRMS. 

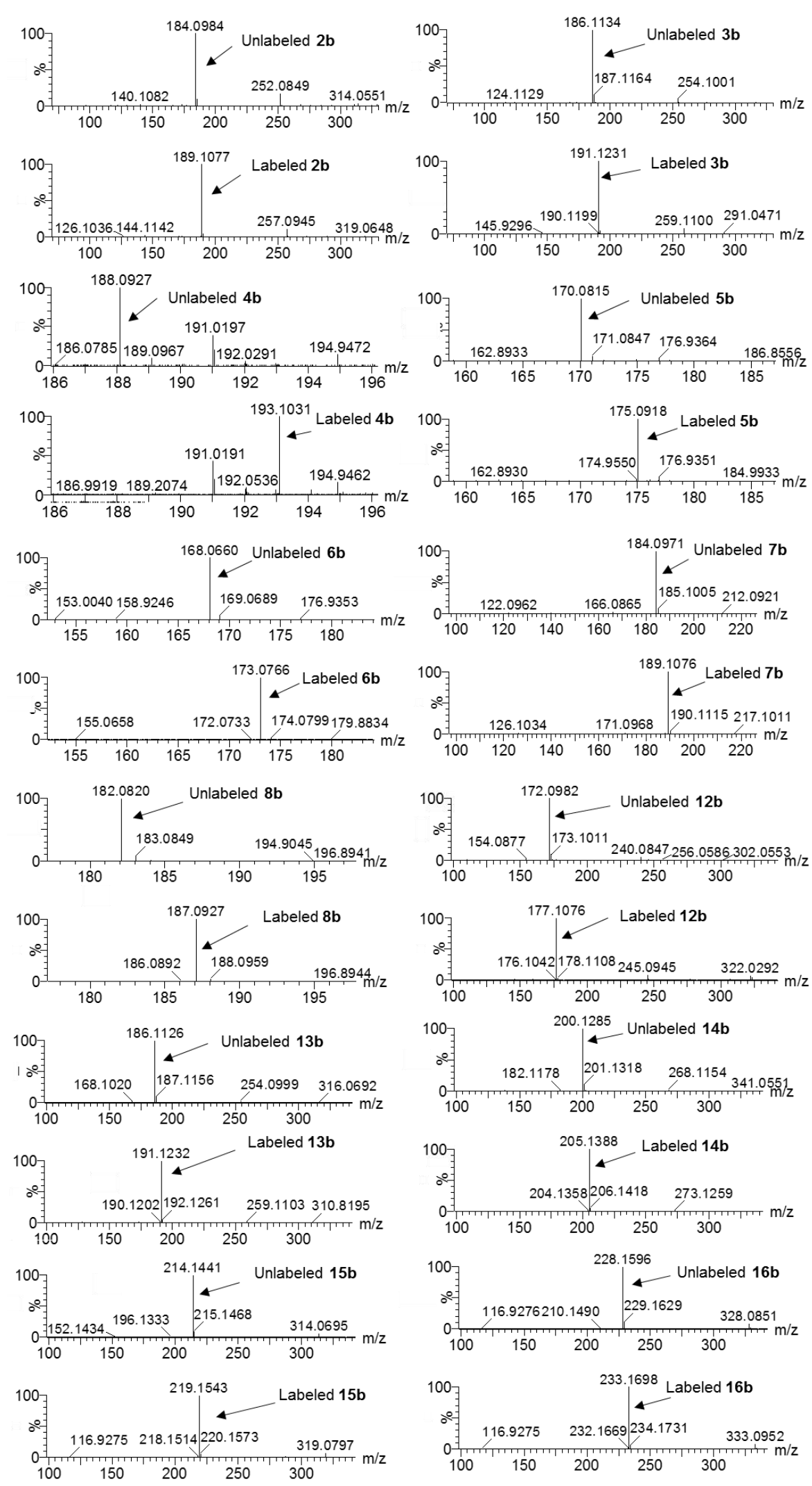

Figure S15. HRMS (ESI-) analysis of the $\alpha$-ketoamine products in stable isotope labeling experiments using $\mathrm{L}^{-13} \mathrm{C}_{5},{ }^{15} \mathrm{~N}$-glutamate in one-pot reaction 

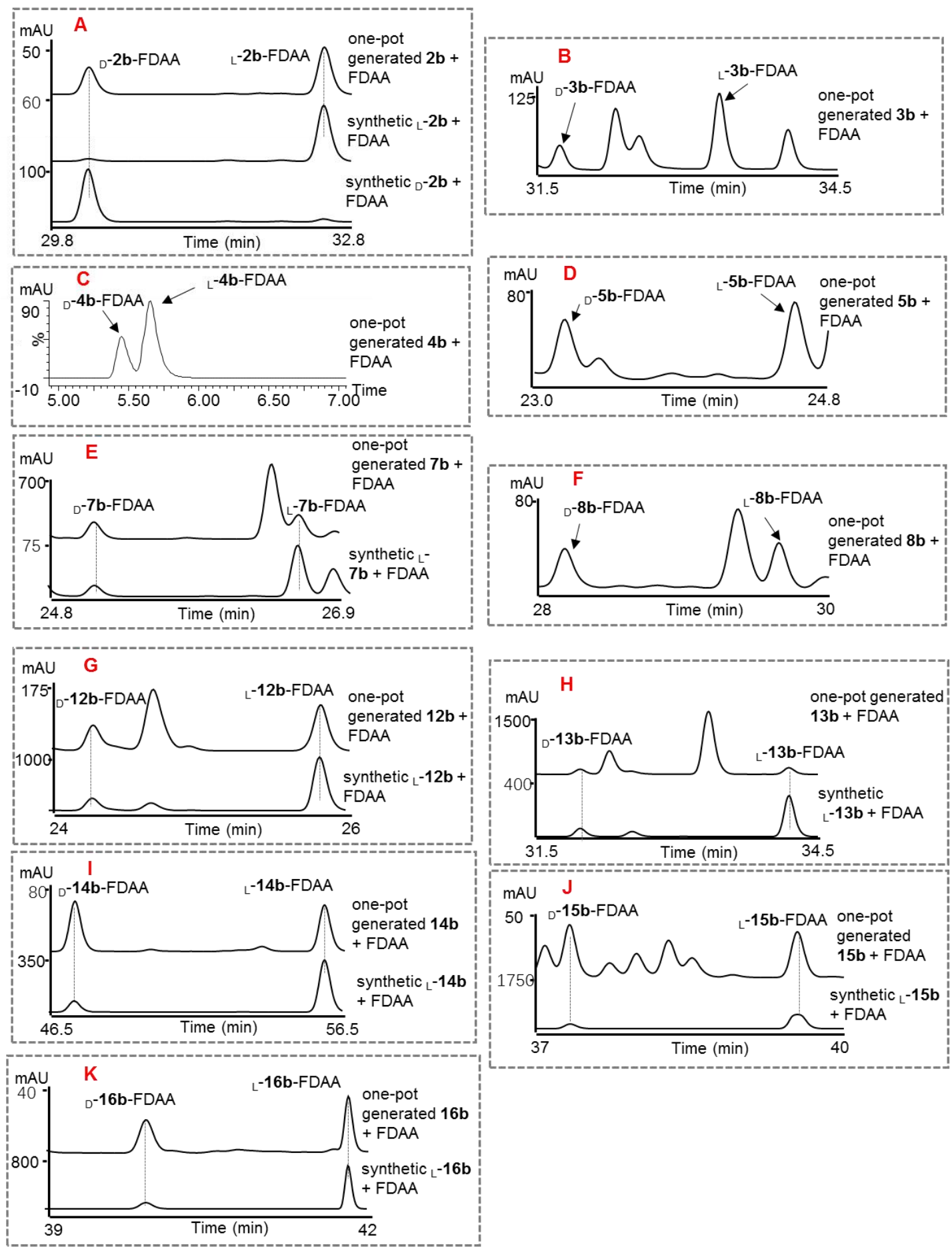

Figure S16. HPLC analysis of the FDAA derivatives of the $\alpha$-ketoamine products from one-pot reaction

2b (A), 3b (B), 4b (C), 5b (D), 7b (E), 8b (F), 12b (G), 13b (H), 14b (I), 15b (J) and $16 \mathrm{~b}(\mathrm{~K})$ formed in one-pot reaction.

The analysis of $\mathbf{4 b}$-FDAA was performed by UPLC-HRMS. 


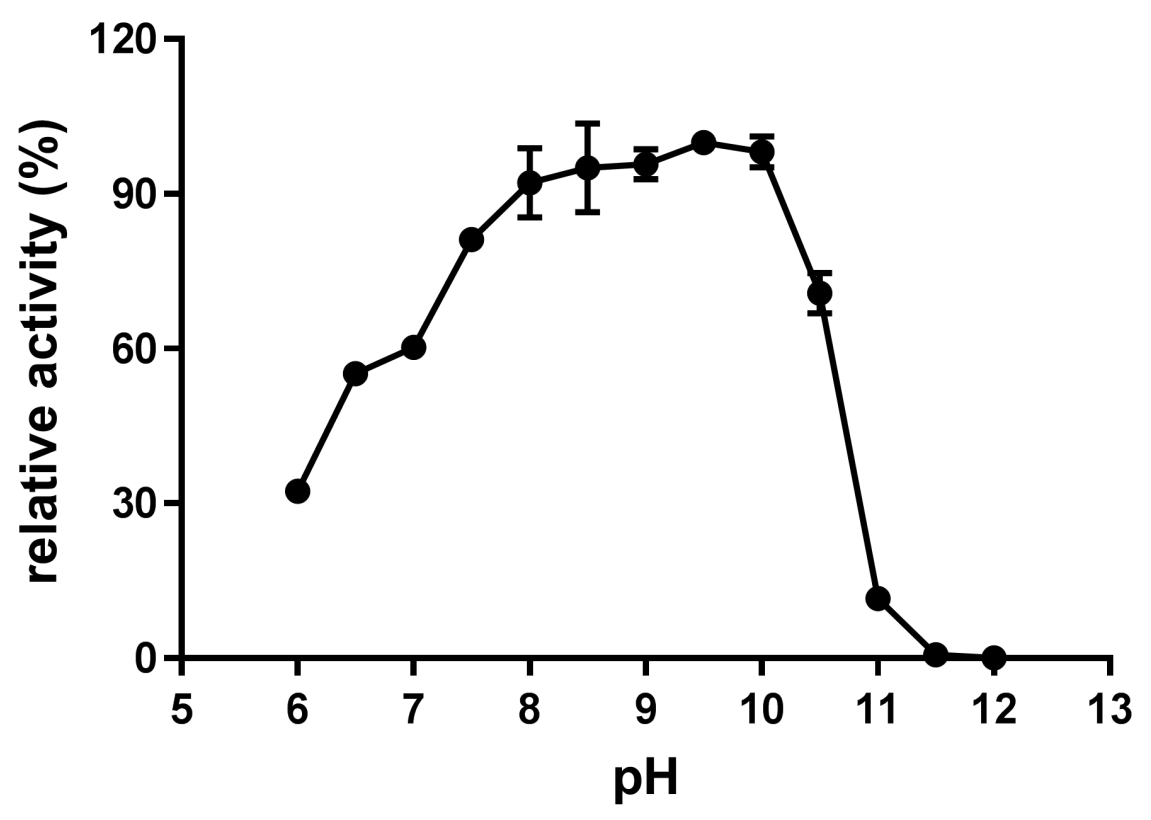

Figure S17. Effect of pH on Alb29 activity

The assay was conducted in a $50 \mu \mathrm{L}$ scale with $20 \mathrm{mM}$ PBK buffer with different $\mathrm{pH}$ values ranging from 6.0 to 12 . The reaction was started with $2 \mu \mathrm{M}$ Alb29, $100 \mu \mathrm{M}$ PLP, $1 \mathrm{mM}_{\mathrm{L}}-\mathrm{Glu}, 100 \mu \mathrm{M} \mathrm{2a}$, incubated at $30^{\circ} \mathrm{C}$ for $15 \mathrm{~min}$. The Alb29 activity was measured by HPLC analysis of the peak area of products $\mathbf{2 b}$ at $254 \mathrm{~nm}$. Reactions were run in triplicate. The optimum $\mathrm{pH}$ was found to be 9.5 . 


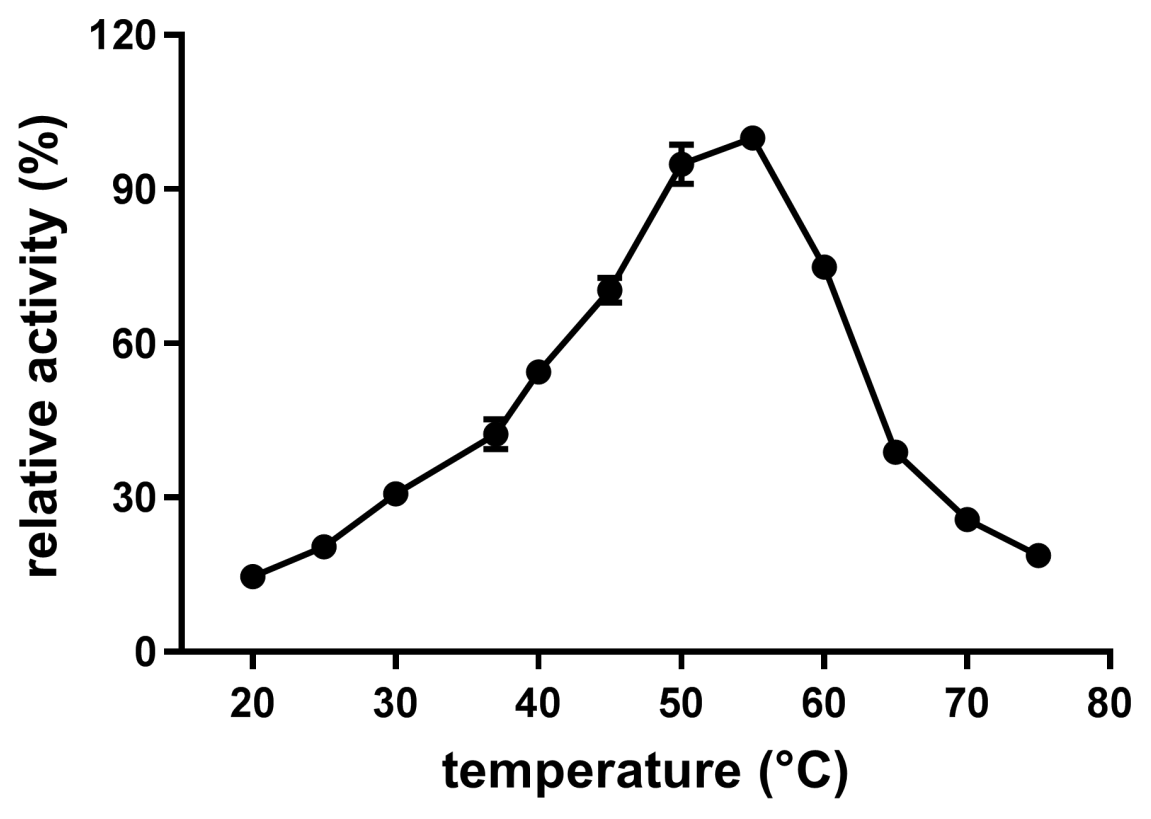

Figure S18. Effect of temperature on Alb29 activity

The assay was conducted in a $50 \mu \mathrm{L}$ scale with $20 \mathrm{mM}$ PBK buffer, pH 9.0, at different temperatures (from 20 to $75^{\circ} \mathrm{C}$ ). The reaction was performed with $0.4 \mu \mathrm{M}$ Alb29, $100 \mu \mathrm{M}$ PLP, $10 \mathrm{mM}$ L-Glu, $100 \mu \mathrm{M}$ 2a, incubated for $8 \mathrm{~min}$. The Alb29 activity was measured by HPLC analysis of the peak area of products $\mathbf{2 b}$ at $254 \mathrm{~nm}$. Reactions were run in triplicate. The optimum temperature was found to be $55^{\circ} \mathrm{C}$. 

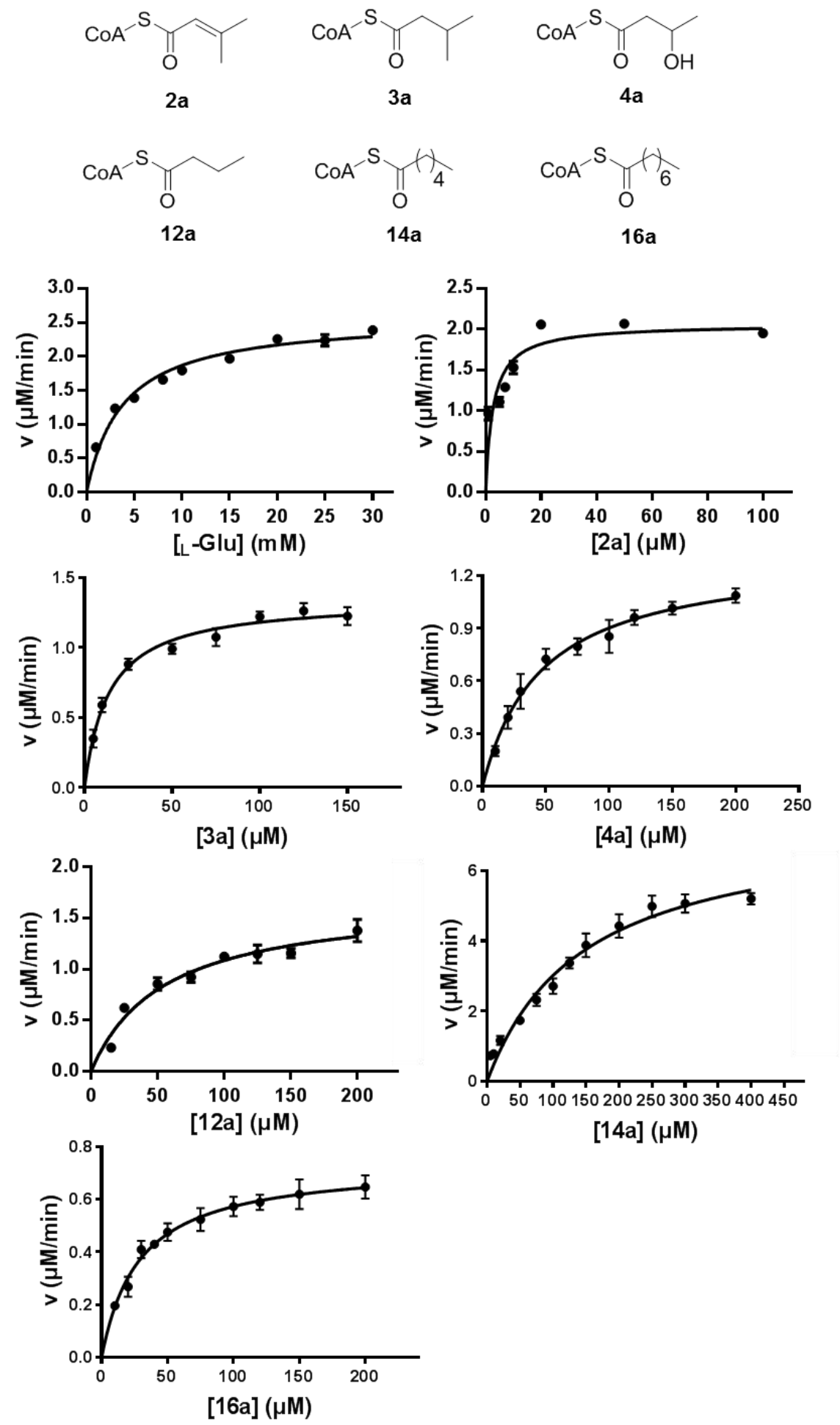

[14a] $(\mu \mathrm{M})$

Figure S19. Kinetic parameters determination of Alb29 towards ${ }_{\text {L-Glu and }}$ acyl-CoAs 2a, 3a, 4a, 12a, 14a and 16a 

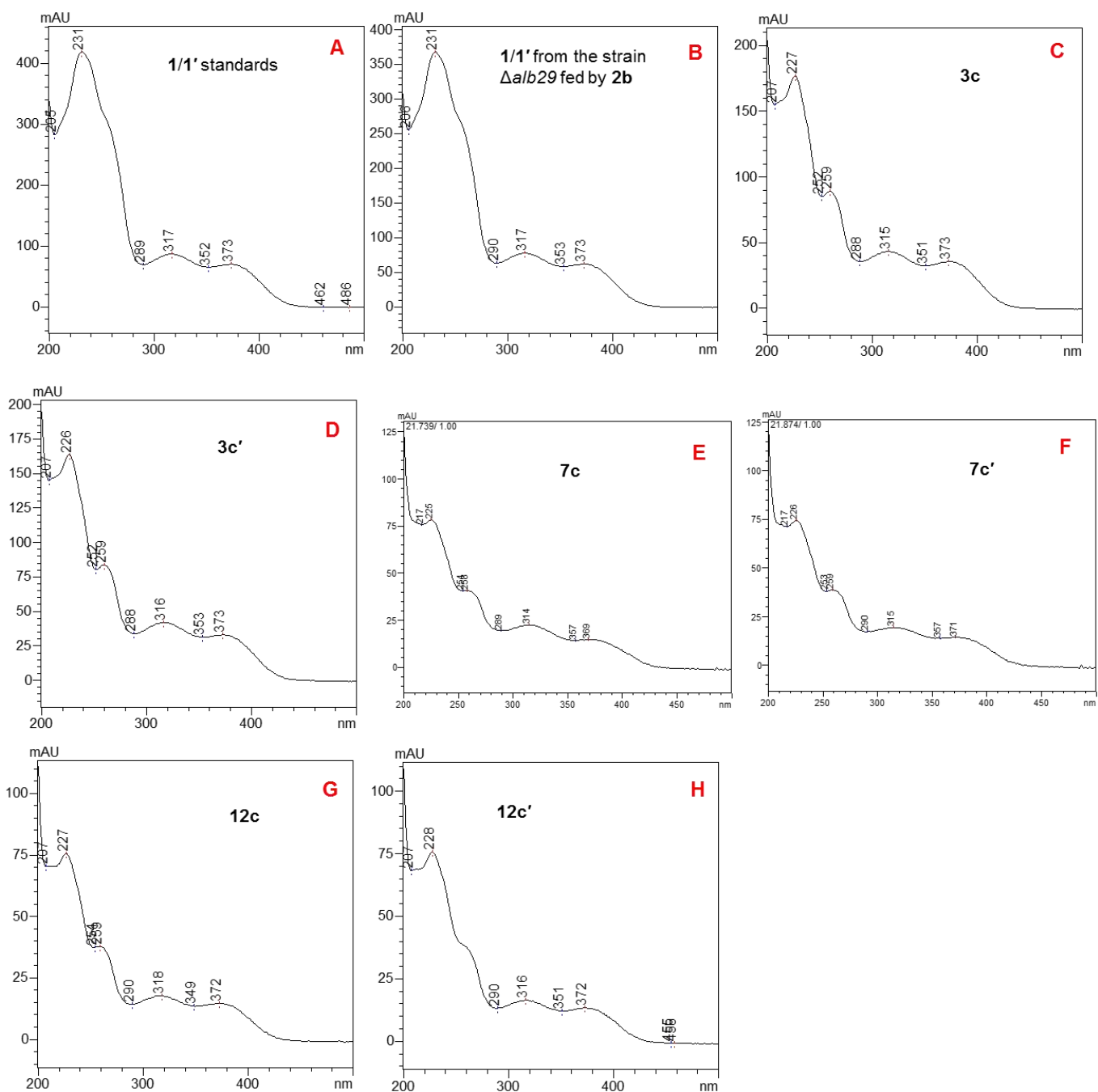

Figure S20. The UV-vis spectra of new albogrisin analogs

The UV-vis spectra of $\mathbf{1} / \mathbf{1}^{\prime}$ standards (A), $\mathbf{1} / \mathbf{1}^{\prime}$ from the strain $\Delta$ alb29 fed by $\mathbf{2 b}$ (B),

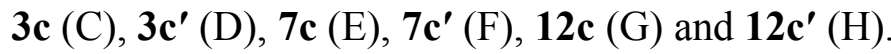



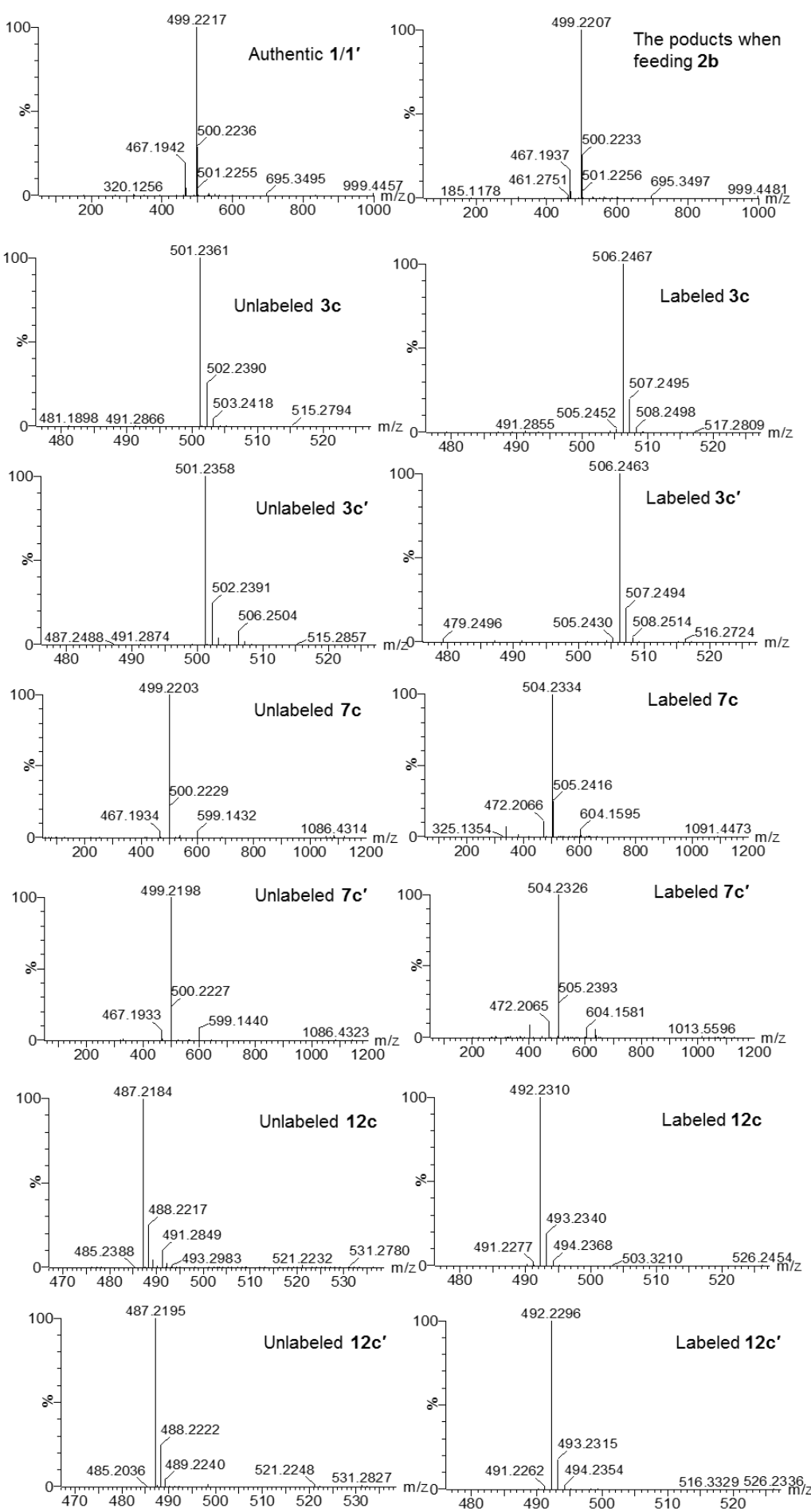

Figure S21. HRMS (ESI-) spectra of albogrisin analogs in stable isotope labeling experiments

The labeled albogrisin analogs $\mathbf{3 c} / \mathbf{3} \mathbf{c}^{\prime}, \mathbf{7 c} / \mathbf{7} \mathbf{c}^{\prime}$ and $\mathbf{1 2 c} / \mathbf{1 2} \mathbf{c}^{\prime}$ were obtained by feeding the labeled $\mathbf{3 b}, \mathbf{7 b}$ and $\mathbf{1 2 b}$ into the strain $\Delta a l b 29$, respectively. The labeled $\mathbf{3 b}, \mathbf{7 b}$, and $\mathbf{1 2 b}$ were generated from the one-pot system with $\mathrm{L}^{-13} \mathrm{C}_{5},{ }^{15} \mathrm{~N}-\mathrm{Glu}$ as the amino acid substrates. 

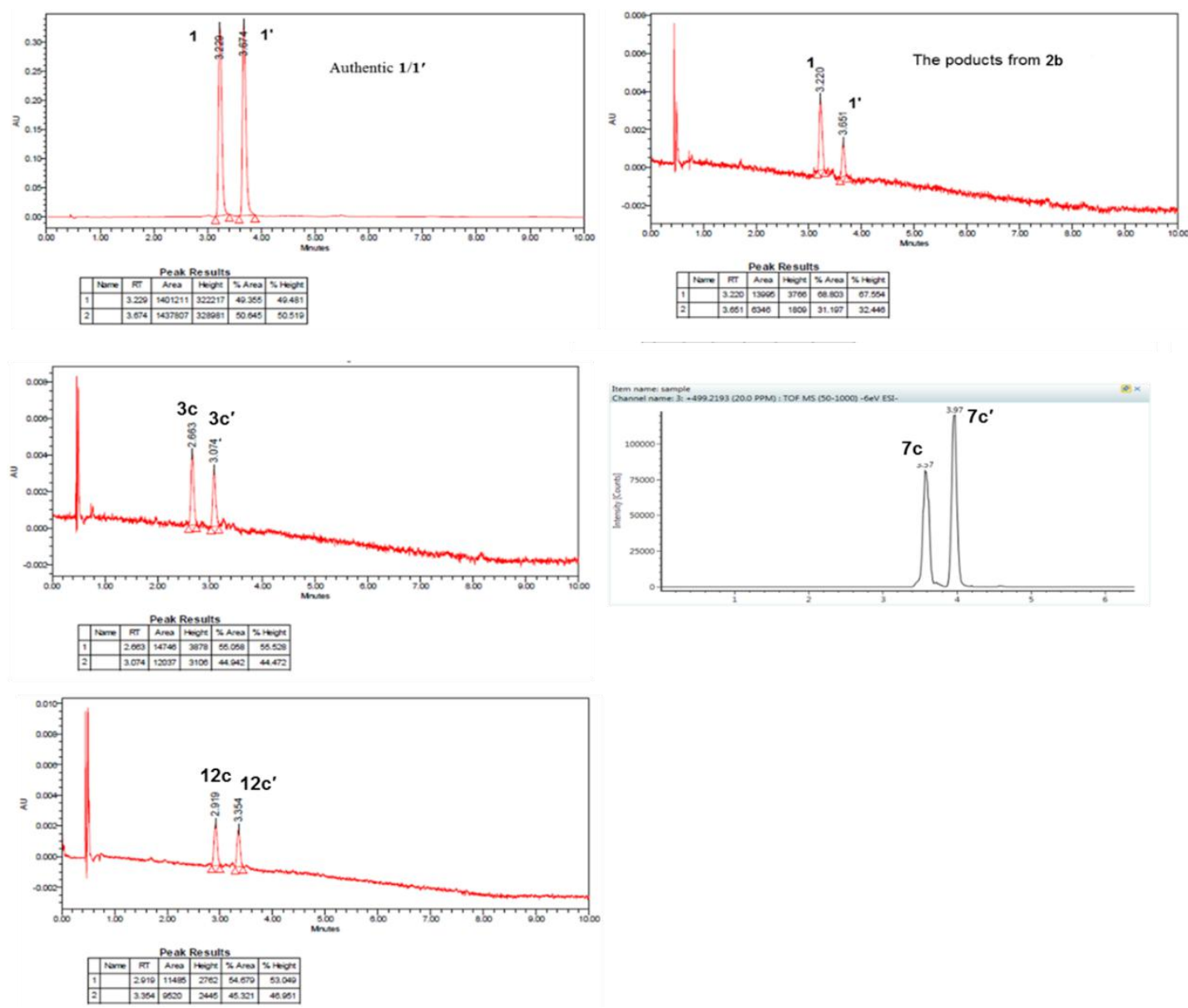

Figure S22. Separation of albogrisin $B(1)$ and $B^{\prime}\left(1^{\prime}\right)$ together with its analogs $\left(3 \mathrm{c} / 3 \mathrm{c}^{\prime}, 7 \mathrm{c} / 7 \mathrm{c}^{\prime}, 12 \mathrm{c} / 12 \mathrm{c}^{\prime}\right)$ by SFC 
A
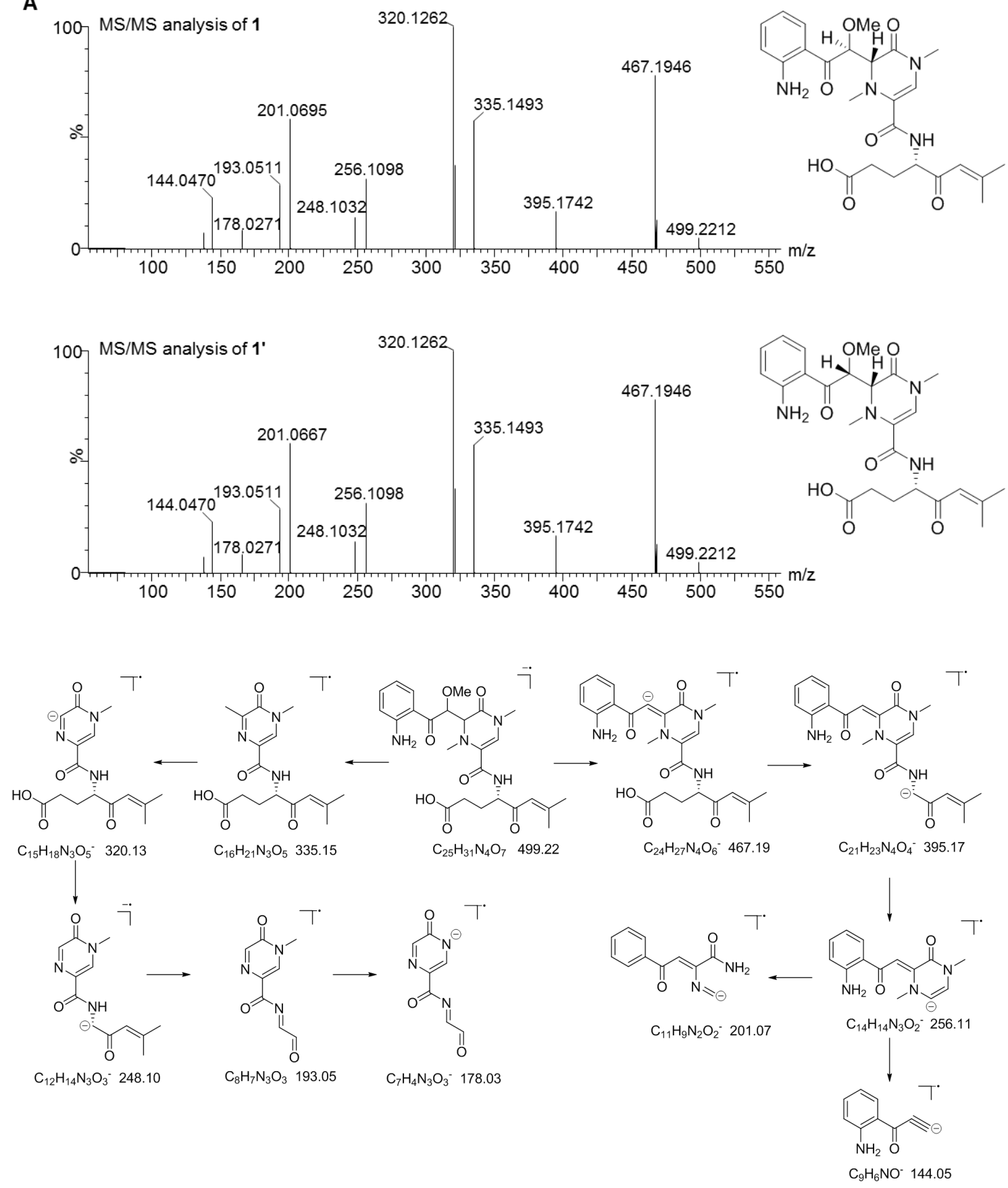
B
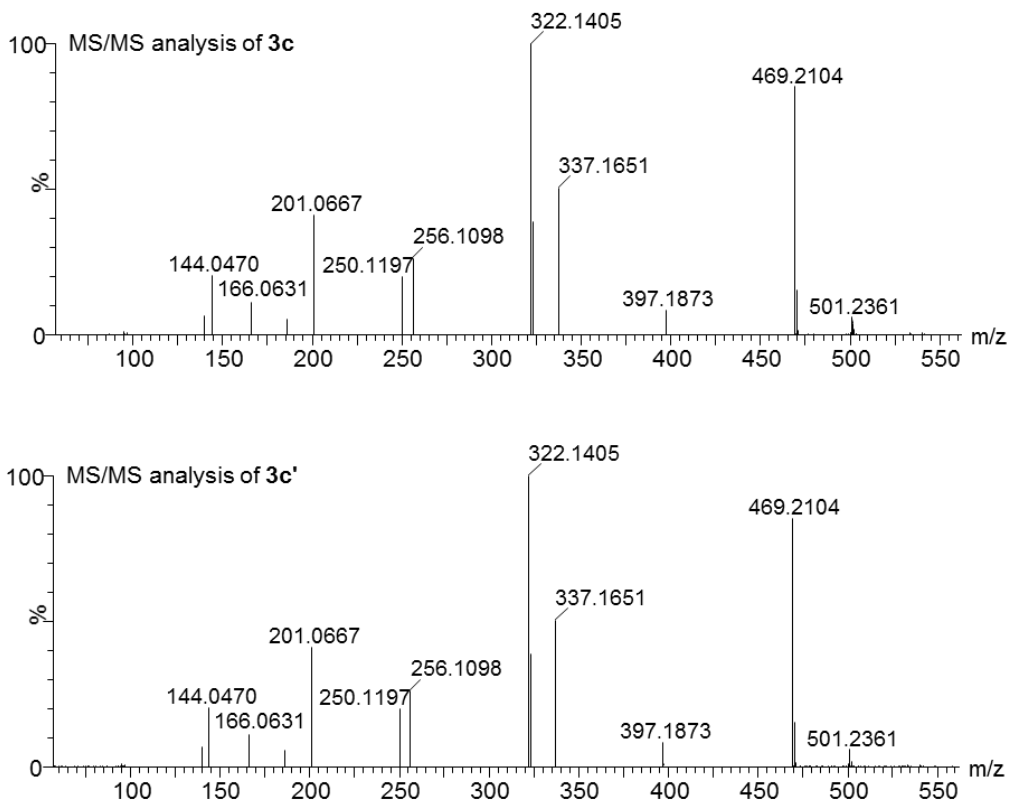

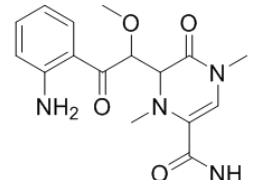

$\mathrm{H}$

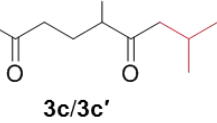

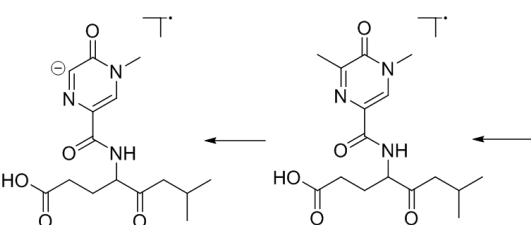

$\mathrm{C}_{15} \mathrm{H}_{20} \mathrm{~N}_{3} \mathrm{O}_{5}-322.14$<smiles>CC(C)CC(=O)ONC(=O)c1cn(CC(C)C)c(=O)cn1</smiles>

$\mathrm{C}_{12} \mathrm{H}_{16} \mathrm{~N}_{3} \mathrm{O}_{3}{ }^{-} 250.12$

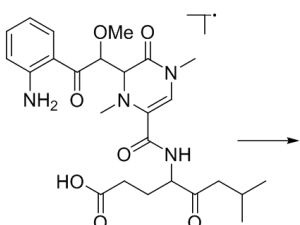

$\mathrm{C}_{25} \mathrm{H}_{33} \mathrm{~N}_{4} \mathrm{O}_{7} \quad 501.23$

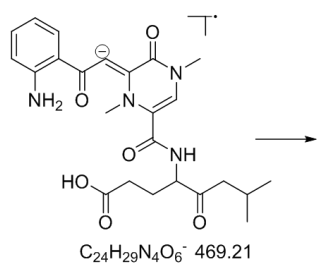

$\mathrm{C}_{24} \mathrm{H}_{29} \mathrm{~N}_{4} \mathrm{O}_{6}-469.21$

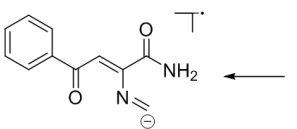

$\mathrm{C}_{11} \mathrm{H}_{9} \mathrm{~N}_{2} \mathrm{O}_{2}-201.07$

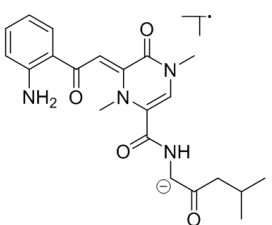

$\mathrm{C}_{21} \mathrm{H}_{25} \mathrm{~N}_{4} \mathrm{O}_{4}-397.19$

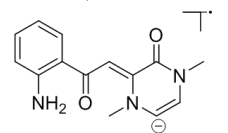

$\mathrm{C}_{14} \mathrm{H}_{14} \mathrm{~N}_{3} \mathrm{O}_{2}{ }^{-2} 256.11$

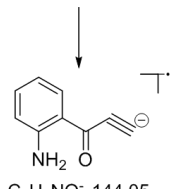

$\mathrm{C}_{9} \mathrm{H}_{6} \mathrm{NO}^{-} 144.05$ 
C
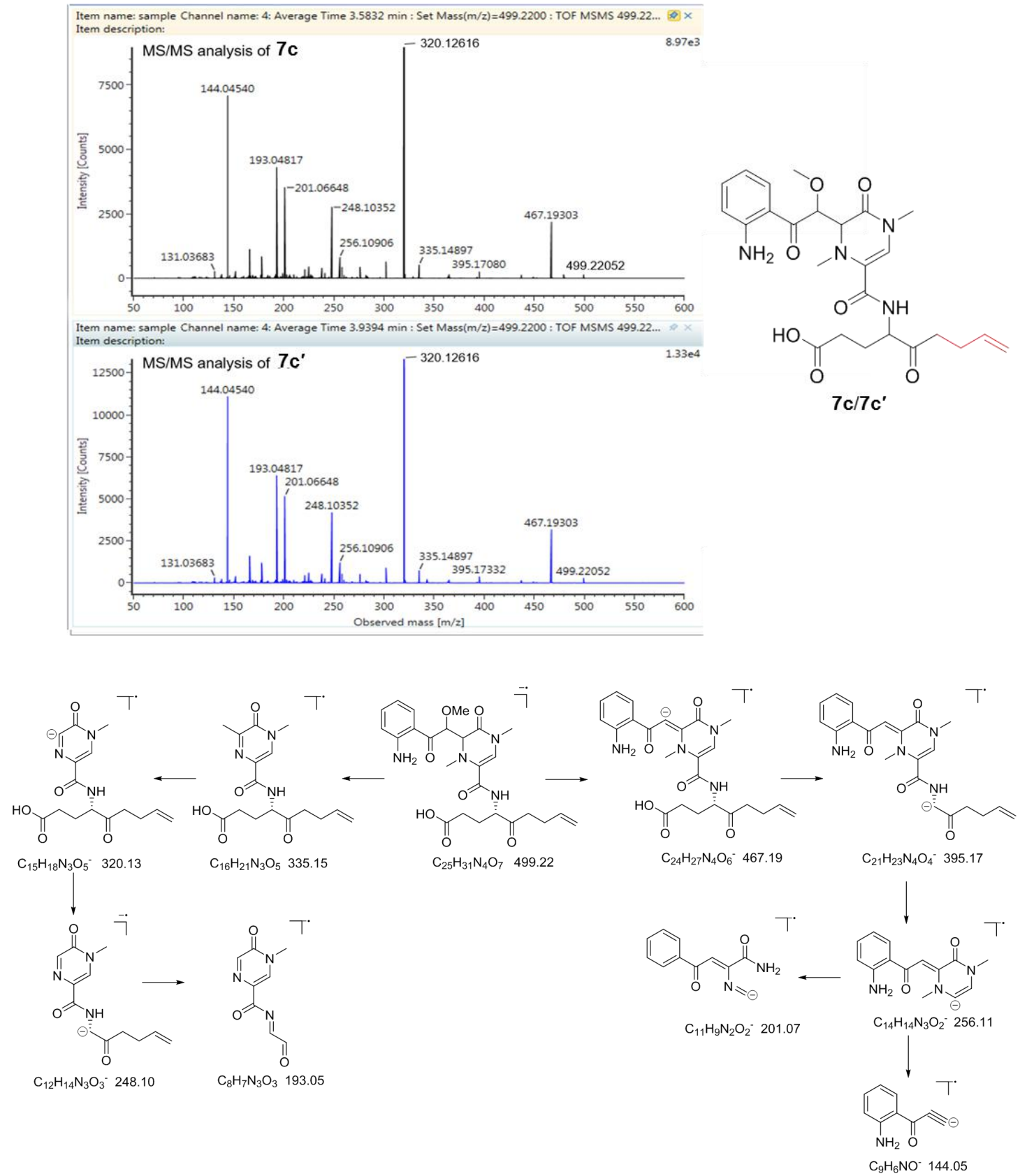
D
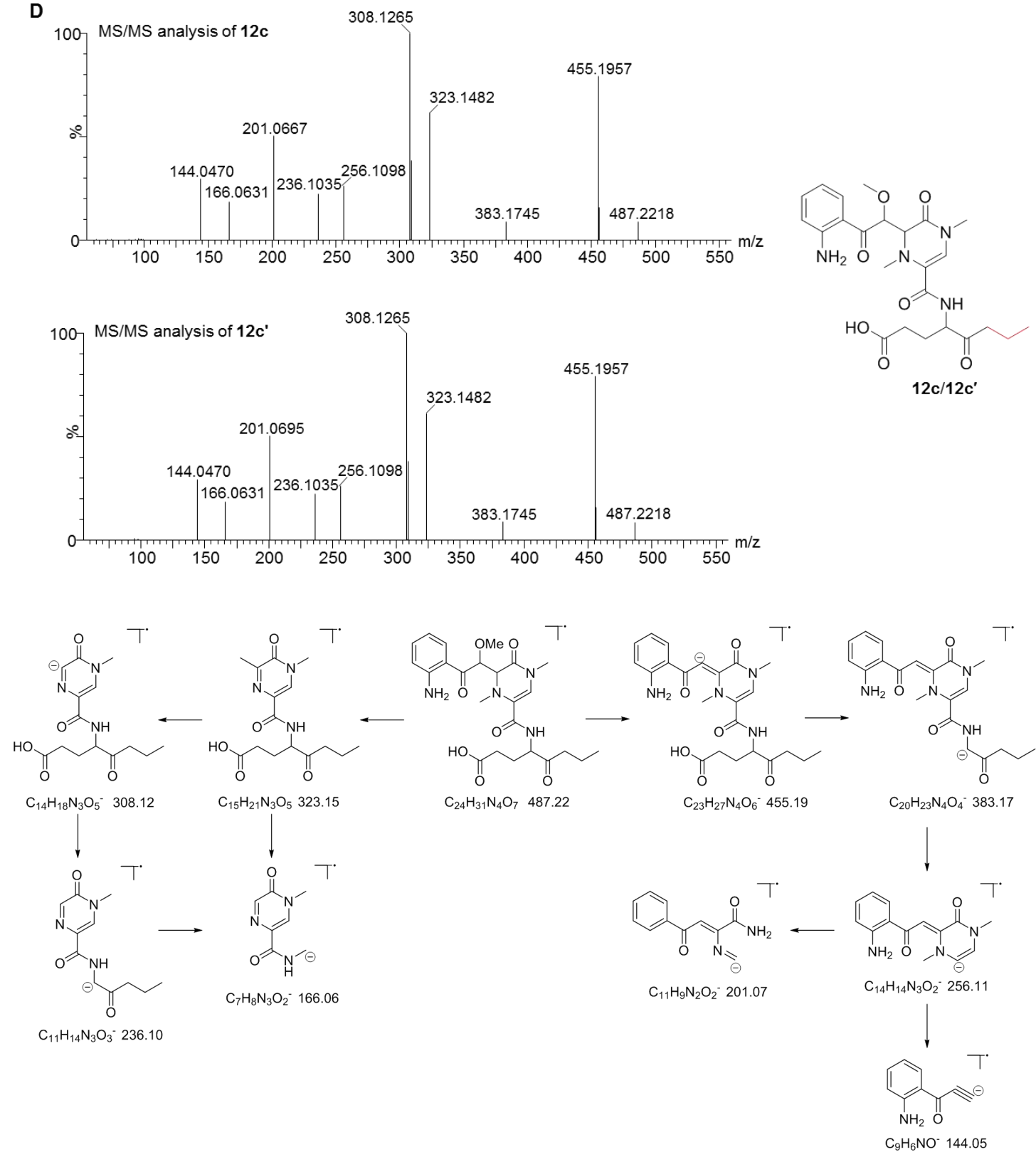

Figure S23. (-) ESI-MS/MS fragmentations of albogrisin analogs by ionization of $[\mathrm{M}-\mathrm{H}]^{-}$and proposed mechanism

(A) Compounds $1 / \mathbf{1}^{\prime}$. (B) Compounds $\mathbf{3 c} / \mathbf{3} \mathbf{c}^{\prime}$. (C) Compounds $\mathbf{7} \mathbf{c} / \mathbf{7} \mathbf{c}^{\prime}$. (D) Compounds $12 \mathrm{c} / \mathbf{1 2} \mathrm{c}^{\prime}$. 

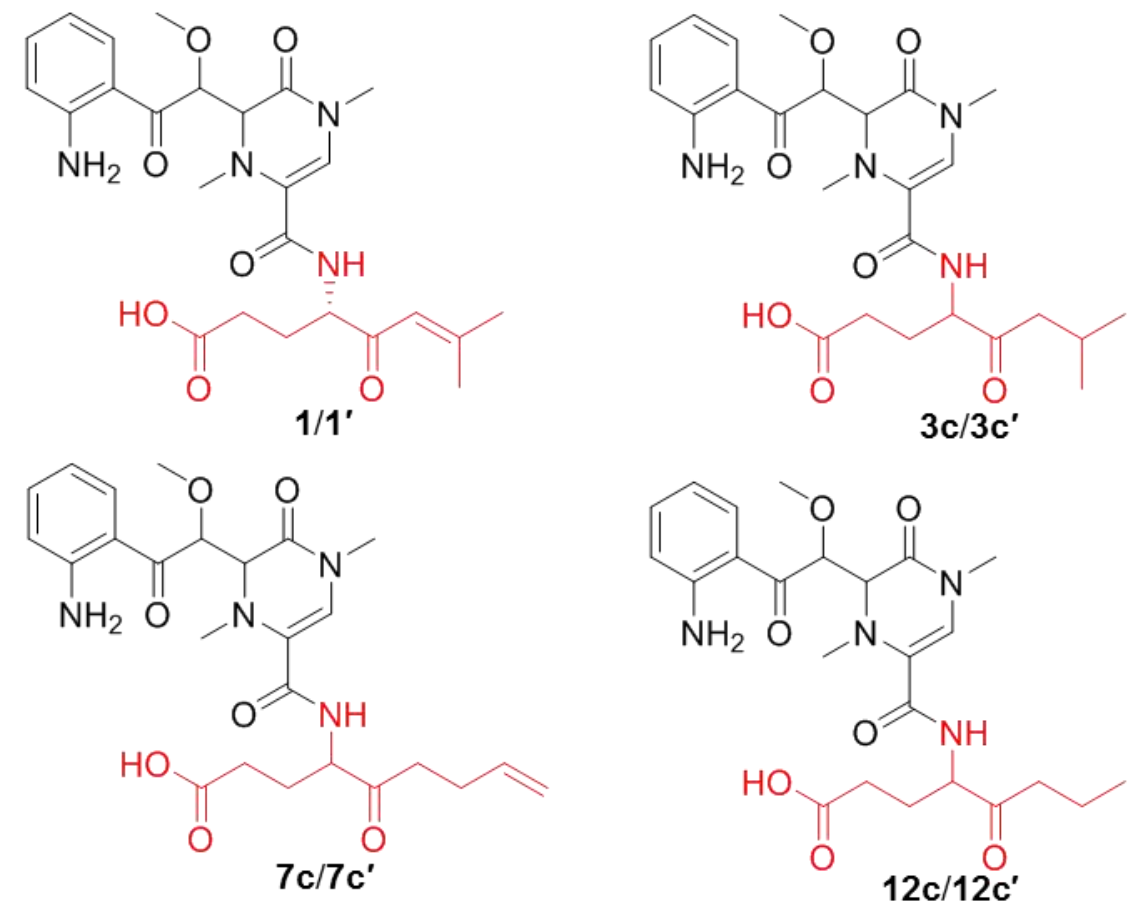

Figure S24. The proposed structures of $3 c / 3 c^{\prime}, 7 c / 7 c^{\prime}$ and $12 c / 12 c^{\prime}$ 


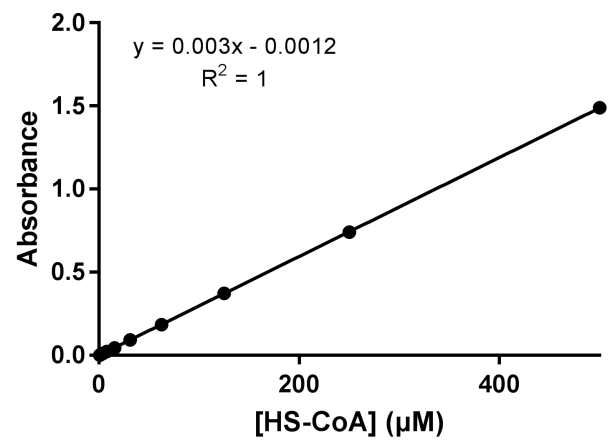

Figure S25. The standard curve showing the absorbance $(412 \mathrm{~nm})$ of different HS-CoA concentrations 

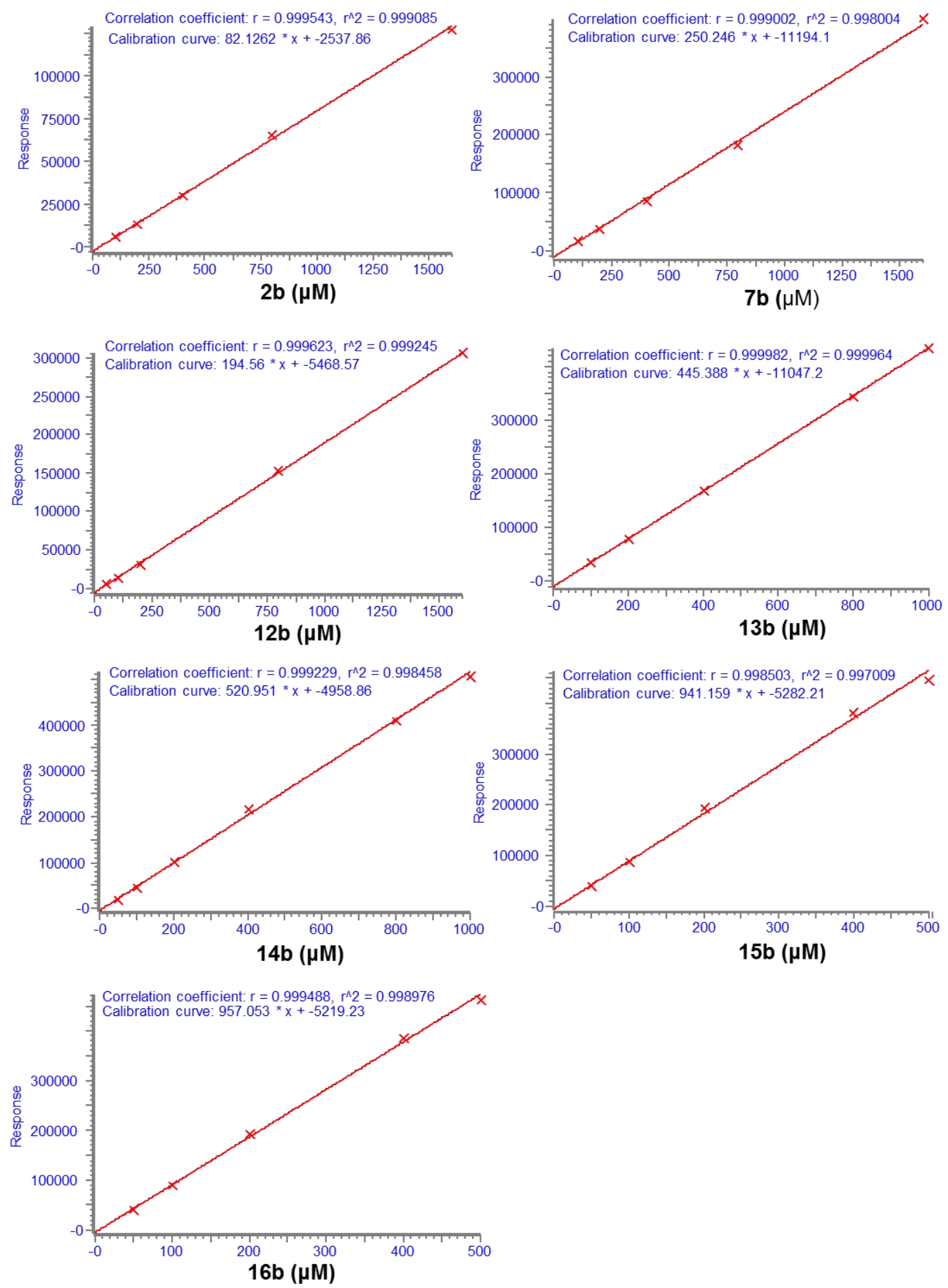

Figure S26. The standard curves representing the relationship between the peak response value of UPLC-APCI-HRMS and different concentrations of $2 b, 7 b$ and 12b-16b 


\section{Supporting Tables}

Table S1. The members of the $\alpha$-oxoamine synthases family found as stand-alone enzymes or components of multi-domain synthases

\begin{tabular}{|c|c|c|c|}
\hline Name & substrate & Pathway & Ref \\
\hline AONS & L-Alanine, pimeloyl-CoA & Biotin biosynthesis & 10 \\
\hline SPT & L-Serine, palmitoyl-CoA & Sphingolipid biosynthesis & 13 \\
\hline ALAS & Glycine, succinyl-CoA & Heme biosynthesis & 14 \\
\hline KBL & Glycine, acetyl-CoA & Threonine degradation & 15 \\
\hline CqsA & $\begin{array}{l}S \text {-Adenosinemethion or } \\
(S) \text {-2-aminobutyrate, } \\
\text { decanoyl-CoA }\end{array}$ & Cholera autoinducer- 1 biosynthesis & 16 \\
\hline KtmB & $\begin{array}{l}\text { L-Phenylalanine, } \\
\text { benzylfumaryl-CoA }\end{array}$ & Ketomemicin biosynthesis & 17 \\
\hline PapD & $\begin{array}{l}\text { 4-Aminophenylalanine, } \\
\text { acetyl-CoA }\end{array}$ & Pyrazine biosynthesis & 18 \\
\hline Fum8p & Alanine, $\mathrm{C}_{18}$-S-ACP & Fumonisins biosynthesis & 19 \\
\hline SxtA & L-Arginine, propionyl-S-ACP & Saxitoxin biosynthesis & $2 \mathrm{a}$ \\
\hline RedL & Glycine, a $\beta$-keto $\mathrm{C}_{14}-\mathrm{S}-\mathrm{ACP}$ & Undecylprodigiosin biosynthesis & 20 \\
\hline RedN & $\begin{array}{l}\text { L-Serine, } \\
\text { pyrrolyl- } \beta \text {-ketoacyl-S-ACP }\end{array}$ & Undecylprodigiosin biosynthesis & 21 \\
\hline LqsA & Unknown & $\begin{array}{l}\text { 3-Hydroxypentadecan-4-one } \\
\text { biosynthesis }\end{array}$ & 22 \\
\hline CuaB & L-Alanine, tetraketide-S-ACP & Curvulamine biosynthesis & 23 \\
\hline ORF34 & Glycine, succinyl-CoA & $\begin{array}{l}\text { 2-Amino-3-hydroxycyclopent-2-enone } \\
\text { biosynthesis }\end{array}$ & 24 \\
\hline
\end{tabular}


Table S2. The DNA sequence of alb29 and the amino acid sequence of Alb29

\begin{abstract}
alb29 (accession no. MN650035) genomic DNA sequence:
atggaaaattcgcgtcacggettctccgacgttaagaagctccggcacctgagtgacggctactgggactcggcggcacggctcggagtcc atggegcagtgctgcaggccgtcccgggaggaagactcagcgcgecggacggtcgagtagcggtcaacatgtcgtcctactcctatctggg getggacgagagcccgaggatcatcgacgecgcgatcgecgcgetgcggagcaacatggtcctgaacagttcgttgtcgcgagtccggat gaccettccgctcctcgaagaagccgagtgcgcactcggcgatctgttcggggcggatgtggcgaccctcaattcgtgctcggcagcggeg tgggccacgttgccggtcctggettccggtctcctcaccgatggtgtcgccccggtgatggtgttcgacaagcgegccatttctgcatggcgt cgctcaagtccetgtgtgccgacgagaccagggtcgagacgatcaggcacaacgacgtcgacgetcttgccgacatctgcaggaagaaca aacgcgtagcttatgtctgcgattccgtctacagcacgggaggaactctagcaccacttgaggaactcttcgcgctccagaaggagttcgggc tcttcctctacttcgacgaagcacatagcacgtcggtaatcggtgacatgggccggggttatgttctggaccggatgggcgcgatcaacgattc gaccatgctcatcacgtcgetgaacaagggtttcggtgcgtcaggcggtgccatcgtgttcggccccagggacgacgaccgcaaacgaaag atcatccagcgcagcagcggeccgttgatgtggtcccagcgtttgaacactccggcactgggegcgatcatcgagtccgccaagctccacc gcagtgaggcgetgcetgagttgcaagccaaactgcacagcaatattgcgcttttcgatggectcgttcgtgccgctggccagggaaacagc gtcccgatccgatacctggagctgggttccgaggtcgatacgctggaagcgtcggettacctgttcgacaacggattctacgtggagccgga cttcttccaatcgtcagcaggggtgcggcgggcetgcgcgeccgaatccggtcctccatgtcgaccgcggacatcgagcagttcgcacac gtgtggcacaagctcggggtcgataagcagtag
\end{abstract}

Alb29 amino acid sequence:

MENSRHGFSDVKKLRHLSDGYWDSAARLGVHGAVLQAVPGGRLSAPDGRVAVNMSSY

SYLGLDESPRIIDAAIAALRSNMVLNSSLSRVRMTLPLLEEAECALGDLFGADVATLNSCS

AAAWATLPVLASGLLTDGVAPVMVFDKRAHFCMASLKSLCADETRVETIRHNDVDALA DICRKNKRVAYVCDSVYSTGGTLAPLEELFALQKEFGLFLYFDEAHSTSVIGDMGRGYVL DRMGAINDSTMLITSLNKGFGASGGAIVFGPRDDDRKRKIIQRSSGPLMWSQRLNTPALG AIIESAKLHRSEALPELQAKLHSNIALFDGLVRAAGQGNSVPIRYLELGSEVDTLEASAYLF DNGFYVEPDFFPIVSRGAAGLRARIRSSMSTADIEQFAHVWHKLGVDKQ 
Table S3. Amino acid sequence identity between Alb29 and other $\alpha$-oxoamine synthases $^{a}$

\begin{tabular}{|c|c|c|c|c|c|}
\hline Alb29 aligns with & AONS & ALAS & KBL & CqsA & KtmB \\
\hline aa & 384 & 549 & 398 & 389 & 389 \\
\hline Identity/Similarity & $26 / 89$ & $24 / 79$ & $25 / 95$ & $25 / 95$ & $42 / 93$ \\
\hline $\begin{array}{l}\text { aONS (PDB ID: } \\
\text { Saccharomyces cere } \\
\text { WP_001039912.1), } \\
\text { mobaraensis. }\end{array}$ & $\begin{array}{l}5 \mathrm{~W}) \\
\mathrm{KBI} \\
o \quad c h\end{array}$ & $\begin{array}{l}\text { coli; } \\
\text { iprot I } \\
e ; \quad \mathrm{K}\end{array}$ & $\begin{array}{l}\mathrm{AS} \\
0 \mathrm{AB} 7 \\
(\mathrm{Ger}\end{array}$ & $\begin{array}{l}\text { Bank } \\
\text { E. coll } \\
\text { ak II }\end{array}$ & $\begin{array}{r}\mathrm{NP} \\
\mathrm{MFOC}(\mathrm{G} \\
\mathrm{MFOC}\end{array}$ \\
\hline
\end{tabular}


Table S4. The DNA sequence of $m g r 36$ and the amino acid sequence of Mgr36

mgr36 (accession no. MN650036) genomic DNA sequence:

gtgctgagcaccatgcaggacgtaccgctgctgatctcgaggatcctgacccacgggtcggcgatccacggcacttctcaggtgatcacctg gaccggtgagggagcccegcagcgccgttcctacgcggagatcggctccegggccgccagctggcgcacgcectgcgcgaggacctc ggcgtcagcggcgacgagcgggtcgccaccetgatgtggaacaacgccgagcacgtcgaggcgtacttcgcgatccctccatgggcgc cgtgctccacacctgaacctcegctcceggccgagcagctcgcgtggatcgtcaaccacgecgeggaccgcgtggtcctcgtcaacgg ctcgetgatccegctgatcgeccegctgetgecgcacctcaagaccgtcgagcacgtcgtcgtctceggecceggegaccgctccecctg gecgacacccacgtccaggtgcacgagtacgaggagctgatcgecggacagcccgtcgcetacgactggecggagctggacgagcggt ccgccgccgccatgtgctacacctceggcaccaccggcgacccaagggcgtggtctacagccaccgttcgatctacctgcactcgatgca ggtgaacatgacccagtccatgggectgaccgaccaggacacctccetggtcgtcgtccegcagttccacgtgaacgcetggggtctgccg cacgccaccttcatgaccggcgtcaacatgctgatgccggaccgettcctgcagccegcccgetcgecgagatgatcgagggcgagaag cccacgcacgecgecgecgtcccaccatctggcagggectgctcgecgagctcaccgccegccecegggacgtctcctcctcacccag gtcaccatcggeggctccgectgecegecgtcgetgatggaggecttcgacaagctgggcatgcgggtctgtcacgectggggcatgacg gagacctcccgetcggcaccatcgccegcctccggccacgccgtcggcaccgacgaggagttcgcctaccggctgacccagggecg cttcceggccggcgtcgaggecegctcaccggccceggeggegagcgectccctgggacggcgagtcegcgggcgagctggaggt gegcggeccetggatcgecggcgectactacaacggeccegacgecgaaccgetgegeceggecgacaagttcagcgacgacggetgg ctcaagaccggcgacgtcggcaccatcagcgccgacggettcctcacctgaccgaccgggccaaggacgtcatcaagtcgggcggcga gtggatctcetcggtggagetggagaacgcgetgatggcgcacceggacgtggecgaggecgecgtggtcgecgtcccegacgacaagt ggggcgagcgeccgctcgccacggtcgtcctcaaggagggttccaccgccgacttcaccacgctgcgcgcettcctccaggacgagggg aagatcgccaagtggcagctgcccgagcgctggacggtgatcgaggcggtgccgaagaccagcgtcggcaagttcgacaagaaggtgct gcgccgcagtacgccgagggcacgctggacgtcacgcagatctga

Mgr36 amino acid sequence:

ALSTMQDVPLLISRILTHGSAIHGTSQVITWTGEGAPQRRSYAEIGSRAAQLAHALREDLG VSGDERVATLMWNNAEHVEAYFAIPSMGAVLHTLNLRLPAEQLAWIVNHAADRVVLVN GSLIPLIAPLLPHLKTVEHVVVSGPGDRSPLADTHVQVHEYEELIAGQPVAYDWPELDERS AAAMCYTSGTTGDPKGVVYSHRSIYLHSMQVNMTQSMGLTDQDTSLVVVPQFHVNAW GLPHATFMTGVNMLMPDRFLQPAPLAEMIEGEKPTHAAAVPTIWQGLLAELTARPRDVS SLTQVTIGGSACPPSLMEAFDKLGMRVCHAWGMTETSPLGTIARPPAHAVGTDEEFAYRL TQGRFPAGVEARLTGPGGERLPWDGESAGELEVRGPWIAGAYYNGPDAEPLRPADKFSD DGWLKTGDVGTISADGFLTLTDRAKDVIKSGGEWISSVELENALMAHPDVAEAAVVAVP DDKWGERPLATVVLKEGSTADFTTLRAFLQDEGKIAKWQLPERWTVIEAVPKTSVGKFD KKVLRRQYAEGTLDVTQI 
Table S5. HRMS data of the Mgr36-generated acyl-CoA products

\begin{tabular}{|c|c|c|c|}
\hline Product & $\begin{array}{l}\text { Calculated } \\
{[\mathrm{M}-\mathrm{H}]^{-}}\end{array}$ & $\begin{array}{l}\text { Detected } \\
{[\mathrm{M}-\mathrm{H}]^{-}}\end{array}$ & Chemical formula \\
\hline $2 a$ & 848.1492 & 848.1473 & $\mathrm{C}_{26} \mathrm{H}_{42} \mathrm{~N}_{7} \mathrm{O}_{17} \mathrm{SP}_{3}$ \\
\hline $3 \mathbf{a}$ & 850.1649 & 850.1628 & $\mathrm{C}_{26} \mathrm{H}_{44} \mathrm{~N}_{7} \mathrm{O}_{17} \mathrm{SP}_{3}$ \\
\hline $4 a$ & 852.1442 & 852.1440 & $\mathrm{C}_{25} \mathrm{H}_{42} \mathrm{~N}_{7} \mathrm{O}_{18} \mathrm{SP}_{3}$ \\
\hline $5 \mathbf{a}$ & 834.1336 & 834.1336 & $\mathrm{C}_{25} \mathrm{H}_{40} \mathrm{~N}_{7} \mathrm{O}_{17} \mathrm{SP}_{3}$ \\
\hline $6 \mathbf{a}$ & 832.1179 & 832.1136 & $\mathrm{C}_{25} \mathrm{H}_{38} \mathrm{~N}_{7} \mathrm{O}_{17} \mathrm{SP}_{3}$ \\
\hline $7 a$ & 848.1492 & 848.1487 & $\mathrm{C}_{26} \mathrm{H}_{42} \mathrm{~N}_{7} \mathrm{O}_{17} \mathrm{SP}_{3}$ \\
\hline $8 \mathbf{a}$ & 846.1336 & 846.1330 & $\mathrm{C}_{26} \mathrm{H}_{40} \mathrm{~N}_{7} \mathrm{O}_{17} \mathrm{SP}_{3}$ \\
\hline $9 a$ & 856.0946 & 856.0946 & $\mathrm{C}_{24} \mathrm{H}_{39} \mathrm{~N}_{7} \mathrm{O}_{17} \mathrm{SClP}_{3}$ \\
\hline $10 \mathrm{a}$ & 808.1179 & 808.1168 & $\mathrm{C}_{23} \mathrm{H}_{38} \mathrm{~N}_{7} \mathrm{O}_{17} \mathrm{SP}_{3}$ \\
\hline $11 \mathrm{a}$ & 822.1336 & 822.1336 & $\mathrm{C}_{24} \mathrm{H}_{40} \mathrm{~N}_{7} \mathrm{O}_{17} \mathrm{SP}_{3}$ \\
\hline $12 \mathrm{a}$ & 836.1492 & 836.1523 & $\mathrm{C}_{25} \mathrm{H}_{42} \mathrm{~N}_{7} \mathrm{O}_{17} \mathrm{SP}_{3}$ \\
\hline $13 \mathrm{a}$ & 850.1649 & 850.1651 & $\mathrm{C}_{26} \mathrm{H}_{44} \mathrm{~N}_{7} \mathrm{O}_{17} \mathrm{SP}_{3}$ \\
\hline $14 a$ & 864.1805 & 864.1816 & $\mathrm{C}_{27} \mathrm{H}_{46} \mathrm{~N}_{7} \mathrm{O}_{17} \mathrm{SP}_{3}$ \\
\hline $15 \mathrm{a}$ & 878.1962 & 878.1979 & $\mathrm{C}_{28} \mathrm{H}_{48} \mathrm{~N}_{7} \mathrm{O}_{17} \mathrm{SP}_{3}$ \\
\hline $16 \mathrm{a}$ & 892.2118 & 892.2155 & $\mathrm{C}_{29} \mathrm{H}_{50} \mathrm{~N}_{7} \mathrm{O}_{17} \mathrm{SP}_{3}$ \\
\hline $20 \mathrm{a}$ & 880.1391 & 880.1398 & $\mathrm{C}_{26} \mathrm{H}_{42} \mathrm{~N}_{7} \mathrm{O}_{19} \mathrm{SP}_{3}$ \\
\hline $21 \mathrm{a}$ & 894.1547 & 894.1565 & $\mathrm{C}_{27} \mathrm{H}_{44} \mathrm{~N}_{7} \mathrm{O}_{19} \mathrm{SP}_{3}$ \\
\hline $22 \mathrm{a}$ & 908.1704 & 908.1695 & $\mathrm{C}_{28} \mathrm{H}_{46} \mathrm{~N}_{7} \mathrm{O}_{19} \mathrm{SP}_{3}$ \\
\hline
\end{tabular}


Table S6. HRMS data of the products synthesized by one-pot reaction of Mgr36 and Alb29

\begin{tabular}{lllll}
\hline Product & $\begin{array}{l}\text { Calculated } \\
{[\mathbf{M}-\mathbf{H}]^{-}}\end{array}$ & $\begin{array}{l}\text { Detected } \\
{[\mathbf{M}-\mathrm{H}]^{-}}\end{array}$ & $\begin{array}{l}\text { Chemical } \\
\text { formula }\end{array}$ & $\begin{array}{l}\text { Labeled product } \\
{\left[\mathbf{M}-\mathrm{H}^{-}\right.}\end{array}$ \\
\hline $\mathbf{2 b}$ & 184.0974 & 184.0984 & $\mathrm{C}_{9} \mathrm{H}_{15} \mathrm{NO}_{3}$ & 189.1077 \\
$\mathbf{3 b}$ & 186.1130 & 186.1134 & $\mathrm{C}_{9} \mathrm{H}_{17} \mathrm{NO}_{3}$ & 191.1231 \\
$\mathbf{4 b}$ & 188.0923 & 188.0927 & $\mathrm{C}_{8} \mathrm{H}_{15} \mathrm{NO}_{4}$ & 193.1031 \\
$\mathbf{5 b}$ & 170.0817 & 170.0815 & $\mathrm{C}_{8} \mathrm{H}_{13} \mathrm{NO}_{3}$ & 175.0918 \\
$\mathbf{6 b}$ & 168.0661 & 168.0660 & $\mathrm{C}_{8} \mathrm{H}_{11} \mathrm{NO}_{3}$ & 173.0766 \\
$\mathbf{7 b}$ & 184.0974 & 184.0971 & $\mathrm{C}_{9} \mathrm{H}_{15} \mathrm{NO}_{3}$ & 189.1076 \\
$\mathbf{8 b}$ & 182.0817 & 182.0820 & $\mathrm{C}_{9} \mathrm{H}_{13} \mathrm{NO}_{3}$ & 187.0927 \\
$\mathbf{1 2 b}$ & 172.0974 & 172.0982 & $\mathrm{C}_{8} \mathrm{H}_{15} \mathrm{NO}_{3}$ & 177.1076 \\
$\mathbf{1 3 b}$ & 186.1130 & 186.1126 & $\mathrm{C}_{9} \mathrm{H}_{17} \mathrm{NO}_{3}$ & 191.1232 \\
$\mathbf{1 4 b}$ & 200.1287 & 200.1285 & $\mathrm{C}_{10} \mathrm{H}_{19} \mathrm{NO}_{3}$ & 205.1388 \\
$\mathbf{1 5 b}$ & 214.1443 & 214.1441 & $\mathrm{C}_{11} \mathrm{H}_{21} \mathrm{NO}_{3}$ & 219.1543 \\
$\mathbf{1 6 b}$ & 228.1600 & 228.1596 & $\mathrm{C}_{12} \mathrm{H}_{23} \mathrm{NO}_{3}$ & 233.1698 \\
\hline
\end{tabular}


Table S7. HRMS data and ratio of the FDAA derivatives of $2 b$ analogs

\begin{tabular}{|c|c|c|c|c|}
\hline FDAA product & $\begin{array}{l}\text { D }\left(\mathrm{RT}^{a}, \text { detected }^{+}\right. \\
{\left[\mathrm{M}+\mathrm{H}^{+}\right) \text {; }} \\
\mathrm{L}\left(\mathrm{RT}^{a}, \text { detected }\right. \\
{\left[\mathrm{M}+\mathrm{H}^{+}\right)}\end{array}$ & $\begin{array}{l}\text { Calculated } \\
{[\mathbf{M}+\mathbf{H}]^{+}}\end{array}$ & $\begin{array}{l}\text { Chemical } \\
\text { formula }\end{array}$ & $\begin{array}{l}\text { The ratio of } D: L \\
\text { ( from one-pot } \\
\text { reaction) }\end{array}$ \\
\hline 2b-FDAA & $\begin{array}{l}\text { D (30.05, 438.1615), } \\
\text { L (32.02, 438.1617); }\end{array}$ & 438.1625 & $\mathrm{C}_{18} \mathrm{H}_{23} \mathrm{~N}_{5} \mathrm{O}_{8}$ & $1: 1.7$ \\
\hline 3b-FDAA & $\begin{array}{l}\text { D (31.72, 440.1764), } \\
\text { L (33.92, 440.1758); }\end{array}$ & 440.1781 & $\mathrm{C}_{18} \mathrm{H}_{25} \mathrm{~N}_{5} \mathrm{O}_{8}$ & $1: 1.8$ \\
\hline 4b-FDAA & $\begin{array}{l}\mathrm{D}(5.45,442.1560) \\
\mathrm{L}(5.64,442.1546)\end{array}$ & 442.1574 & $\mathrm{C}_{17} \mathrm{H}_{23} \mathrm{~N}_{5} \mathrm{O}_{9}$ & $1: 2.2$ \\
\hline 5b-FDAA & $\begin{array}{l}\text { D (23.16, 424.1470), } \\
\text { L (24.42, 424.1453); }\end{array}$ & 424.1468 & $\mathrm{C}_{17} \mathrm{H}_{21} \mathrm{~N}_{5} \mathrm{O}_{8}$ & $1: 1.3$ \\
\hline 7b-FDAA & $\begin{array}{l}\text { D (25.11, 438.1622), } \\
\text { L (26.52, 438.1627); }\end{array}$ & 438.1625 & $\mathrm{C}_{18} \mathrm{H}_{23} \mathrm{~N}_{5} \mathrm{O}_{8}$ & $1: 1.0$ \\
\hline 8b-FDAA & $\begin{array}{l}\text { D }(28.18,436.1443) \\
\text { L (29.66, 436.1462); }\end{array}$ & 436.1468 & $\mathrm{C}_{18} \mathrm{H}_{21} \mathrm{~N}_{5} \mathrm{O}_{8}$ & $1: 1.1$ \\
\hline 12b-FDAA & $\begin{array}{l}\text { D (24.28, 426.1606), } \\
\text { L (25.81, 426.1607); }\end{array}$ & 426.1625 & $\mathrm{C}_{17} \mathrm{H}_{23} \mathrm{~N}_{5} \mathrm{O}_{8}$ & $1: 1.6$ \\
\hline 13b-FDAA & $\begin{array}{l}\text { D (31.98, 440.1761), } \\
\text { L (34.19, 440.1773); }\end{array}$ & 440.1781 & $\mathrm{C}_{18} \mathrm{H}_{25} \mathrm{~N}_{5} \mathrm{O}_{8}$ & $1: 1.4$ \\
\hline 14b-FDAA & $\begin{array}{l}\text { D (46.82, 454.1923), } \\
\text { L (50.23, 454.1924); }\end{array}$ & 454.1938 & $\mathrm{C}_{19} \mathrm{H}_{27} \mathrm{~N}_{5} \mathrm{O}_{8}$ & $1: 0.9$ \\
\hline 15b-FDAA & $\begin{array}{l}\text { D (37.32, 468.2100), } \\
\text { L (39.55, 468.2092); }\end{array}$ & 468.2094 & $\mathrm{C}_{20} \mathrm{H}_{29} \mathrm{~N}_{5} \mathrm{O}_{8}$ & $1: 0.9$ \\
\hline 16b-FDAA & $\begin{array}{l}\mathrm{D}(39.93,482.2238) \\
\mathrm{L}(41.82,482.2238)\end{array}$ & 482.2251 & $\mathrm{C}_{21} \mathrm{H}_{31} \mathrm{~N}_{5} \mathrm{O}_{8}$ & $1: 1.1$ \\
\hline
\end{tabular}

${ }^{a} \mathrm{RT}$ : Retention time. 
Table S8. Kinetic properties of Alb29

Kinetic parameters $( \pm \mathrm{SD})$ were determined by nonlinear regression analysis of the data to the Michaelis-Menten equation.

\begin{tabular}{|c|c|c|c|c|}
\hline Substrate & $K_{\mathrm{m}}(\mu \mathrm{M})$ & $\begin{array}{c}V_{\max } \\
\left(\text { nmol min }^{-1} \mathrm{mg}_{\text {protein }}{ }^{-1}\right)\end{array}$ & $k_{\text {cat }}\left(\mathbf{s}^{-1}\right)$ & $\begin{array}{l}k_{\mathrm{cat}} / K_{\mathrm{m}} \\
\left(\mathbf{s}^{-1} \mathbf{M}^{-1}\right)\end{array}$ \\
\hline${ }_{\mathrm{L}}$-Glu & $3826 \pm 320$ & $136 \pm 3$ & $0.108 \pm 0.003$ & 28.2 \\
\hline $2 \mathbf{a}$ & $2.69 \pm 0.65$ & $108 \pm 5$ & $0.086 \pm 0.004$ & 31970 \\
\hline $\mathbf{3 a}$ & $13.95 \pm 1.31$ & $61.4 \pm 1.3$ & $0.049 \pm 0.001$ & 3491 \\
\hline $4 a$ & $46.74 \pm 5.00$ & $5.36 \pm 0.2$ & $0.00424 \pm 0.0002$ & 90.7 \\
\hline $12 \mathrm{a}$ & $55.09 \pm 8.45$ & $70.7 \pm 0.4$ & $0.056 \pm 0.004$ & 1017 \\
\hline $14 a$ & $147.1 \pm 17.0$ & $168.3 \pm 8.5$ & $0.134 \pm 0.0067$ & 910.9 \\
\hline $16 \mathbf{a}$ & $28.58 \pm 2.67$ & $3.34 \pm 0.09$ & $0.00265 \pm 0.00007$ & 92.7 \\
\hline
\end{tabular}


Table S9. HRMS data of the new albogrisin analogs

\begin{tabular}{lllll}
\hline Product & $\begin{array}{l}\text { Calculated } \\
{\left[\mathbf{M}-\mathbf{H}^{-}\right.}\end{array}$ & $\begin{array}{l}\text { Detected } \\
{[\mathbf{M}-\mathrm{H}]^{-}}\end{array}$ & $\begin{array}{l}\text { Chemical } \\
\text { formula }\end{array}$ & $\begin{array}{l}\text { Labeled product } \\
{\left[\mathbf{M}-\mathrm{H}^{-}\right.}\end{array}$ \\
\hline $\begin{array}{l}\text { Authentic 1/1' } \\
\text { The products when } \\
\text { feeding 2b }\end{array}$ & 499.2193 & 499.2217 & $\mathrm{C}_{25} \mathrm{H}_{32} \mathrm{~N}_{4} \mathrm{O}_{7}$ & - \\
$\mathbf{3 c}$ & 499.2193 & 499.2207 & $\mathrm{C}_{25} \mathrm{H}_{32} \mathrm{~N}_{4} \mathrm{O}_{7}$ & - \\
$\mathbf{3} \mathbf{c}^{\prime}$ & 501.2349 & 501.2361 & $\mathrm{C}_{25} \mathrm{H}_{34} \mathrm{~N}_{4} \mathrm{O}_{7}$ & 506.2467 \\
$\mathbf{7 c}$ & 501.2349 & 501.2358 & $\mathrm{C}_{25} \mathrm{H}_{34} \mathrm{~N}_{4} \mathrm{O}_{7}$ & 506.2463 \\
$\mathbf{7 c ^ { \prime }}$ & 499.2193 & 499.2203 & $\mathrm{C}_{25} \mathrm{H}_{32} \mathrm{~N}_{4} \mathrm{O}_{7}$ & 504.2334 \\
$\mathbf{1 2 c}$ & 499.2193 & 499.2198 & $\mathrm{C}_{25} \mathrm{H}_{32} \mathrm{~N}_{4} \mathrm{O}_{7}$ & 504.2326 \\
$\mathbf{1 2 c ^ { \prime }}$ & 487.2193 & 487.2184 & $\mathrm{C}_{24} \mathrm{H}_{32} \mathrm{~N}_{4} \mathrm{O}_{7}$ & 492.2310 \\
\hline
\end{tabular}


Table S10. The SFC-MS/MS fragment ions of albogrisin analogs in the negative mode

\begin{tabular}{|c|c|c|c|}
\hline Compound & $m / z$ found & $m / z$ calculated & $\begin{array}{l}\text { Formula } \\
\text { composition }\end{array}$ \\
\hline \multirow[t]{11}{*}{1} & 499.2212 & 499.2193 & $\mathrm{C}_{25} \mathrm{H}_{31} \mathrm{~N}_{4} \mathrm{O}_{7}$ \\
\hline & 467.1946 & 467.1931 & $\mathrm{C}_{24} \mathrm{H}_{27} \mathrm{~N}_{4} \mathrm{O}_{6}$ \\
\hline & 395.1742 & 395.1719 & $\mathrm{C}_{21} \mathrm{H}_{23} \mathrm{~N}_{4} \mathrm{O}_{4}$ \\
\hline & 335.1493 & 335.1481 & $\mathrm{C}_{16} \mathrm{H}_{21} \mathrm{~N}_{3} \mathrm{O}_{5}$ \\
\hline & 320.1262 & 320.1246 & $\mathrm{C}_{15} \mathrm{H}_{18} \mathrm{~N}_{3} \mathrm{O}_{5}$ \\
\hline & 256.1098 & 256.1086 & $\mathrm{C}_{14} \mathrm{H}_{14} \mathrm{~N}_{3} \mathrm{O}_{2}$ \\
\hline & 248.1032 & 248.1035 & $\mathrm{C}_{12} \mathrm{H}_{14} \mathrm{~N}_{3} \mathrm{O}_{3}$ \\
\hline & 201.0695 & 201.0664 & $\mathrm{C}_{11} \mathrm{H}_{9} \mathrm{~N}_{2} \mathrm{O}_{2}$ \\
\hline & 193.0511 & 193.0487 & $\mathrm{C}_{8} \mathrm{H}_{7} \mathrm{~N}_{3} \mathrm{O}_{3}$ \\
\hline & 178.0271 & 178.0253 & $\mathrm{C}_{7} \mathrm{H}_{4} \mathrm{~N}_{3} \mathrm{O}_{3}$ \\
\hline & 144.0470 & 144.0449 & $\mathrm{C}_{9} \mathrm{H}_{6} \mathrm{NO}$ \\
\hline \multirow[t]{11}{*}{$1^{\prime}$} & 499.2212 & 499.2193 & $\mathrm{C}_{25} \mathrm{H}_{31} \mathrm{~N}_{4} \mathrm{O}_{7}$ \\
\hline & 467.1946 & 467.1931 & $\mathrm{C}_{24} \mathrm{H}_{27} \mathrm{~N}_{4} \mathrm{O}_{6}$ \\
\hline & 395.1742 & 395.1719 & $\mathrm{C}_{21} \mathrm{H}_{23} \mathrm{~N}_{4} \mathrm{O}_{4}$ \\
\hline & 335.1493 & 335.1481 & $\mathrm{C}_{16} \mathrm{H}_{21} \mathrm{~N}_{3} \mathrm{O}_{5}$ \\
\hline & 320.1262 & 320.1246 & $\mathrm{C}_{15} \mathrm{H}_{18} \mathrm{~N}_{3} \mathrm{O}_{5}$ \\
\hline & 256.1098 & 256.1086 & $\mathrm{C}_{14} \mathrm{H}_{14} \mathrm{~N}_{3} \mathrm{O}_{2}$ \\
\hline & 248.1032 & 248.1035 & $\mathrm{C}_{12} \mathrm{H}_{14} \mathrm{~N}_{3} \mathrm{O}_{3}$ \\
\hline & 201.0667 & 201.0664 & $\mathrm{C}_{11} \mathrm{H}_{9} \mathrm{~N}_{2} \mathrm{O}_{2}$ \\
\hline & 193.0511 & 193.0487 & $\mathrm{C}_{8} \mathrm{H}_{7} \mathrm{~N}_{3} \mathrm{O}_{3}$ \\
\hline & 178.0271 & 178.0253 & $\mathrm{C}_{7} \mathrm{H}_{4} \mathrm{~N}_{3} \mathrm{O}_{3}$ \\
\hline & 144.0470 & 144.0449 & $\mathrm{C}_{9} \mathrm{H}_{6} \mathrm{NO}$ \\
\hline \multirow[t]{3}{*}{$3 c$} & 501.2361 & 501.2349 & $\mathrm{C}_{25} \mathrm{H}_{33} \mathrm{~N}_{4} \mathrm{O}_{7}$ \\
\hline & 469.2104 & 469.2087 & $\mathrm{C}_{24} \mathrm{H}_{29} \mathrm{~N}_{4} \mathrm{O}_{6}$ \\
\hline & 397.1873 & 397.1876 & $\mathrm{C}_{21} \mathrm{H}_{25} \mathrm{~N}_{4} \mathrm{O}_{4}$ \\
\hline
\end{tabular}




\begin{tabular}{|c|c|c|c|}
\hline & 337.1651 & 337.1638 & $\mathrm{C}_{16} \mathrm{H}_{23} \mathrm{~N}_{3} \mathrm{O}_{5}$ \\
\hline & 322.1405 & 322.1403 & $\mathrm{C}_{15} \mathrm{H}_{20} \mathrm{~N}_{3} \mathrm{O}_{5}$ \\
\hline & 256.1098 & 256.1086 & $\mathrm{C}_{14} \mathrm{H}_{14} \mathrm{~N}_{3} \mathrm{O}_{2}$ \\
\hline & 250.1197 & 250.1218 & $\mathrm{C}_{12} \mathrm{H}_{16} \mathrm{~N}_{3} \mathrm{O}_{3}$ \\
\hline & 201.0667 & 201.0664 & $\mathrm{C}_{11} \mathrm{H}_{9} \mathrm{~N}_{2} \mathrm{O}_{2}$ \\
\hline & 166.0631 & 166.0617 & $\mathrm{C}_{7} \mathrm{H}_{8} \mathrm{~N}_{3} \mathrm{O}_{2}$ \\
\hline & 144.0470 & 144.0449 & $\mathrm{C}_{9} \mathrm{H}_{6} \mathrm{NO}$ \\
\hline \multirow[t]{10}{*}{$3 c^{\prime}$} & 501.2361 & 501.2349 & $\mathrm{C}_{25} \mathrm{H}_{33} \mathrm{~N}_{4} \mathrm{O}_{7}$ \\
\hline & 469.2104 & 469.2087 & $\mathrm{C}_{24} \mathrm{H}_{29} \mathrm{~N}_{4} \mathrm{O}_{6}$ \\
\hline & 397.1873 & 397.1876 & $\mathrm{C}_{21} \mathrm{H}_{25} \mathrm{~N}_{4} \mathrm{O}_{4}$ \\
\hline & 337.1651 & 337.1638 & $\mathrm{C}_{16} \mathrm{H}_{23} \mathrm{~N}_{3} \mathrm{O}_{5}$ \\
\hline & 322.1405 & 322.1403 & $\mathrm{C}_{15} \mathrm{H}_{20} \mathrm{~N}_{3} \mathrm{O}_{5}$ \\
\hline & 256.1098 & 256.1086 & $\mathrm{C}_{14} \mathrm{H}_{14} \mathrm{~N}_{3} \mathrm{O}_{2}$ \\
\hline & 250.1197 & 250.1218 & $\mathrm{C}_{12} \mathrm{H}_{16} \mathrm{~N}_{3} \mathrm{O}_{3}$ \\
\hline & 201.0667 & 201.0664 & $\mathrm{C}_{11} \mathrm{H}_{9} \mathrm{~N}_{2} \mathrm{O}_{2}$ \\
\hline & 166.0631 & 166.0617 & $\mathrm{C}_{7} \mathrm{H}_{8} \mathrm{~N}_{3} \mathrm{O}_{2}$ \\
\hline & 144.0470 & 144.0449 & $\mathrm{C}_{9} \mathrm{H}_{6} \mathrm{NO}$ \\
\hline \multirow[t]{10}{*}{$7 \mathrm{c}$} & 499.22052 & 499.2193 & $\mathrm{C}_{25} \mathrm{H}_{31} \mathrm{~N}_{4} \mathrm{O}_{7}$ \\
\hline & 467.19303 & 467.1931 & $\mathrm{C}_{24} \mathrm{H}_{27} \mathrm{~N}_{4} \mathrm{O}_{6}$ \\
\hline & 395.17080 & 395.1719 & $\mathrm{C}_{21} \mathrm{H}_{23} \mathrm{~N}_{4} \mathrm{O}_{4}$ \\
\hline & 335.14897 & 335.1481 & $\mathrm{C}_{16} \mathrm{H}_{21} \mathrm{~N}_{3} \mathrm{O}_{5}$ \\
\hline & 320.12616 & 320.1246 & $\mathrm{C}_{15} \mathrm{H}_{18} \mathrm{~N}_{3} \mathrm{O}_{5}$ \\
\hline & 256.10906 & 256.1086 & $\mathrm{C}_{14} \mathrm{H}_{14} \mathrm{~N}_{3} \mathrm{O}_{2}$ \\
\hline & 248.10352 & 248.1035 & $\mathrm{C}_{12} \mathrm{H}_{14} \mathrm{~N}_{3} \mathrm{O}_{3}$ \\
\hline & 201.06648 & 201.0664 & $\mathrm{C}_{11} \mathrm{H}_{9} \mathrm{~N}_{2} \mathrm{O}_{2}$ \\
\hline & 193.04817 & 193.0487 & $\mathrm{C}_{8} \mathrm{H}_{7} \mathrm{~N}_{3} \mathrm{O}_{3}$ \\
\hline & 144.04540 & 144.0449 & $\mathrm{C}_{9} \mathrm{H}_{6} \mathrm{NO}$ \\
\hline \multirow[t]{2}{*}{$7 c^{\prime}$} & 499.22052 & 499.2193 & $\mathrm{C}_{25} \mathrm{H}_{31} \mathrm{~N}_{4} \mathrm{O}_{7}$ \\
\hline & 467.19303 & 467.1931 & $\mathrm{C}_{24} \mathrm{H}_{27} \mathrm{~N}_{4} \mathrm{O}_{6}$ \\
\hline
\end{tabular}




\begin{tabular}{|c|c|c|c|}
\hline & 395.17332 & 395.1719 & $\mathrm{C}_{21} \mathrm{H}_{23} \mathrm{~N}_{4} \mathrm{O}_{4}$ \\
\hline & 335.14897 & 335.1481 & $\mathrm{C}_{16} \mathrm{H}_{21} \mathrm{~N}_{3} \mathrm{O}_{5}$ \\
\hline & 320.12616 & 320.1246 & $\mathrm{C}_{15} \mathrm{H}_{18} \mathrm{~N}_{3} \mathrm{O}_{5}$ \\
\hline & 256.10906 & 256.1086 & $\mathrm{C}_{14} \mathrm{H}_{14} \mathrm{~N}_{3} \mathrm{O}_{2}$ \\
\hline & 248.10352 & 248.1035 & $\mathrm{C}_{12} \mathrm{H}_{14} \mathrm{~N}_{3} \mathrm{O}_{3}$ \\
\hline & 201.06648 & 201.0664 & $\mathrm{C}_{11} \mathrm{H}_{9} \mathrm{~N}_{2} \mathrm{O}_{2}$ \\
\hline & 193.04817 & 193.0487 & $\mathrm{C}_{8} \mathrm{H}_{7} \mathrm{~N}_{3} \mathrm{O}_{3}$ \\
\hline & 144.04540 & 144.0449 & $\mathrm{C}_{9} \mathrm{H}_{6} \mathrm{NO}$ \\
\hline \multirow[t]{10}{*}{$12 \mathrm{c}$} & 487.2218 & 487.2193 & $\mathrm{C}_{24} \mathrm{H}_{31} \mathrm{~N}_{4} \mathrm{O}_{7}$ \\
\hline & 455.1957 & 455.1931 & $\mathrm{C}_{23} \mathrm{H}_{27} \mathrm{~N}_{4} \mathrm{O}_{6}$ \\
\hline & 383.1745 & 383.1719 & $\mathrm{C}_{20} \mathrm{H}_{23} \mathrm{~N}_{4} \mathrm{O}_{4}$ \\
\hline & 323.1482 & 323.1481 & $\mathrm{C}_{15} \mathrm{H}_{21} \mathrm{~N}_{3} \mathrm{O}_{5}$ \\
\hline & 308.1265 & 308.1246 & $\mathrm{C}_{14} \mathrm{H}_{18} \mathrm{~N}_{3} \mathrm{O}_{5}$ \\
\hline & 256.1098 & 256.1126 & $\mathrm{C}_{14} \mathrm{H}_{14} \mathrm{~N}_{3} \mathrm{O}_{2}$ \\
\hline & 236.1035 & 236.1035 & $\mathrm{C}_{11} \mathrm{H}_{14} \mathrm{~N}_{3} \mathrm{O}_{3}$ \\
\hline & 201.0667 & 201.0664 & $\mathrm{C}_{11} \mathrm{H}_{9} \mathrm{~N}_{2} \mathrm{O}_{2}$ \\
\hline & 166.0631 & 166.0617 & $\mathrm{C}_{7} \mathrm{H}_{8} \mathrm{~N}_{3} \mathrm{O}_{2}$ \\
\hline & 144.0470 & 144.0449 & $\mathrm{C}_{9} \mathrm{H}_{6} \mathrm{NO}$ \\
\hline \multirow[t]{10}{*}{$12 c^{\prime}$} & 487.2218 & 487.2193 & $\mathrm{C}_{24} \mathrm{H}_{31} \mathrm{~N}_{4} \mathrm{O}_{7}$ \\
\hline & 455.1957 & 455.1931 & $\mathrm{C}_{23} \mathrm{H}_{27} \mathrm{~N}_{4} \mathrm{O}_{6}$ \\
\hline & 383.1745 & 383.1719 & $\mathrm{C}_{20} \mathrm{H}_{23} \mathrm{~N}_{4} \mathrm{O}_{4}$ \\
\hline & 323.1482 & 323.1481 & $\mathrm{C}_{15} \mathrm{H}_{21} \mathrm{~N}_{3} \mathrm{O}_{5}$ \\
\hline & 308.1265 & 308.1246 & $\mathrm{C}_{14} \mathrm{H}_{18} \mathrm{~N}_{3} \mathrm{O}_{5}$ \\
\hline & 256.1098 & 256.1126 & $\mathrm{C}_{14} \mathrm{H}_{14} \mathrm{~N}_{3} \mathrm{O}_{2}$ \\
\hline & 236.1035 & 236.1035 & $\mathrm{C}_{11} \mathrm{H}_{14} \mathrm{~N}_{3} \mathrm{O}_{3}$ \\
\hline & 201.0695 & 201.0664 & $\mathrm{C}_{11} \mathrm{H}_{9} \mathrm{~N}_{2} \mathrm{O}_{2}$ \\
\hline & 166.0631 & 166.0617 & $\mathrm{C}_{7} \mathrm{H}_{8} \mathrm{~N}_{3} \mathrm{O}_{2}$ \\
\hline & 144.0470 & 144.0449 & $\mathrm{C}_{9} \mathrm{H}_{6} \mathrm{NO}$ \\
\hline
\end{tabular}


Table S11. Strains and plasmids used in this study

\begin{tabular}{|c|c|c|}
\hline Strain & Relevant properties & Source \\
\hline \multicolumn{3}{|l|}{ E. coli } \\
\hline DH5 $\alpha$ & Host for general DNA manipulation & TaKaRa \\
\hline BL21 (DE3) & Host for recombinant protein expression & Novagen \\
\hline ET12567/pUZ8002 & $\begin{array}{l}\text { Donor strain for conjugation between E. coli and } \\
\text { Streptomyces, recF dam dcm hsdS/pUZ8002 }\end{array}$ & 25 \\
\hline \multicolumn{3}{|l|}{ Streptomyces } \\
\hline S. albogriseolus & Wild-type albogrisin-producing strain & 26 \\
\hline \multicolumn{3}{|l|}{ MGR072 } \\
\hline$\Delta a l b 29$ & alb29 in-frame deletion mutant & This work \\
\hline$\Delta a l b 29:: \mathrm{pHrdB}$ & $\Delta$ alb29 complemented with blank vector $\mathrm{pHrdB}$ & This work \\
\hline$\Delta a l b 29:: p H r d B-29$ & $\begin{array}{l}\Delta a l b 29 \text { complemented with alb29 under the control of } \\
\text { promoter } h r d B^{*} p\end{array}$ & This work \\
\hline \multicolumn{3}{|l|}{ Plasmids } \\
\hline pJTU1278 & bla, tsr, lacZ, oriT, oripIJ101, ori ${ }^{C o l E 1}$ & 3 \\
\hline pD-29 & pJTU1278 derivative for alb29 deletion & This work \\
\hline $\mathrm{pHrdB}$ & pSET152 derivative with $h r d B^{*} p$ & This work \\
\hline pHrdB-29 & pHrdB derivative for complementation of alb29 & This work \\
\hline pET28a & kan, $\mathrm{P}_{\mathrm{T} 7}$, His-tag & Novagen \\
\hline pET28a-29 & pET28a derivative carrying alb29 & This work \\
\hline pET28a-36 & pET28a derivative carrying $m g r 36$ & This work \\
\hline pGro7 & molecular chaperone expression plasmid & TaKaRa \\
\hline
\end{tabular}


Table S12. Primers used in this study and their sequence

\begin{tabular}{|c|c|}
\hline Primes $^{a}$ & Sequence (from $5^{\prime}$ to $\left.3^{\prime}\right)^{b}$ \\
\hline \multirow[t]{2}{*}{ alb29U-F } & GAGCTCCACCGCGGTGGCGGCCGCTCTAGAACGTCATCATGACC \\
\hline & GACGAT \\
\hline alb29U-R & GCAGGTGAGCCTCTGACTCGACCTCCCCCACATTCCCTCTCACAT \\
\hline alb29D-F & GAGGTCGAGTCAGAGGCTCA \\
\hline \multirow[t]{2}{*}{ alb29D-R } & CCCCTCGAGGTCGACGGTATCGATAAGCTTACGCCCTGAACGCC \\
\hline & CGTGAA \\
\hline alb29T-F & TCACGTTCTGAGTTCGAGGC \\
\hline alb29T-R & AAGGTCGAGACGGTGACAAC \\
\hline \multirow[t]{2}{*}{$h r d B-F$} & AAGCTTGGGCTGCAGGTCGACTCTAGACACGGTCCACCCCGAGG \\
\hline & TGGAGCG \\
\hline \multirow[t]{2}{*}{$h r d B-\mathrm{R}$} & TTCGATATCGCGCGCGGCCGCGGATCCCATATGGAACAACCTCT \\
\hline & CGGAACGTTGGAAAAC \\
\hline \multirow[t]{2}{*}{ alb29-pHrdB-F } & GTTTTCCAACGTTCCGAGAGGTTGTTCCATATGATGGAAAATTCG \\
\hline & CGTCACGGCTTCTCC \\
\hline \multirow[t]{2}{*}{ alb29-pHrdB-R } & AAACAGCTATGACATGATTACGAATTCCTAGTGATGATGATGAT \\
\hline & GATGCTGCTTATCGACCCCGAGCTTGTG \\
\hline \multirow[t]{2}{*}{ alb29-28a-F } & GACTGGTGGACAGCAAATGGGTCGCGGATCCATGGAAAATTCGC \\
\hline & GTCACGGCTTCT \\
\hline \multirow[t]{2}{*}{ alb29-28a-R } & GGCCGCAAGCTTGTCGACGGAGCTCGAATTCCTACTGCTTATCG \\
\hline & ACCCCGAGCTTG \\
\hline \multirow[t]{2}{*}{$m g r 36-28 \mathrm{a}-\mathrm{F}$} & GACTGGTGGACAGCAAATGGGTCGCGGATCCATGCTGAGCACCA \\
\hline & TGCAGGACGTAC \\
\hline \multirow[t]{2}{*}{$m g r 36-28 \mathrm{a}-\mathrm{R}$} & GGCCGCAAGCTTGTCGACGGAGCTCGAATTCTCAGATCTGCGTG \\
\hline & ACGTCCAGCGTG \\
\hline
\end{tabular}

${ }^{a} \mathrm{~F}$, forward primer; $\mathrm{R}$, reverse primer.

${ }^{b}$ Restriction endonuclease sites are underlined. 
Table S13. The DNA sequence containing the promoter of orf2284

\section{Sequence:}

cacggtccacccegaggtggagegegtggtgeccgegecgcgegagcactgacegcgtttccecegacggegeggtccggecegccat ccccetcetgtggeggegtcgegtccgtgagecgtccecegtcggaccetgcgacaccgtcgacggtgtcgcagggtccgacggtacgaa acgacgagacgacggtacgaagggecggtcgaagccceggagcggeggectcctcaccectggtgcacgettctgtccetatctggcagg tttgactggctgcggggtgtgactcgggecacgcggaatgggegtaacgctcctgggaggaacgcgatgacctaagaggtgacagccgc ggagggaatacggacgecgttcatggegetgtgcatctccecggectccgeccgegecgtcggeccatccccaagccggeggtcggecc ctgtccactgtggacggggecggaagccgttttccaacgttccgagaggttgttc 
Table S14. The accession numbers of the known AOSs used for phylogenetic analysis of Alb29

\begin{tabular}{lll}
\hline Protein & Organism & Accession \\
\hline AONS & E. coli & WP_000118826.1 \\
ALAS & Saccharomyces cerevisiae & NP_010518.1 \\
KBL & E. coli & WP_001213834.1 \\
SPT & Homo sapiens & NP_006406.1 \\
CqSA & Vibrio cholerae & WP_001039912.1 \\
KtmB & S. mobaraensis & EMF00971.1 \\
PapD & Pseudomonas fluorescens SBW25 & WP_012723046.1 \\
ORF34 & S. aizunensis & AAX98209.1 \\
\hline
\end{tabular}




\section{References}

(1) Ducrot, P.; Rabhi, C.; Thal, C. Tetrahedron 2000, 56, 2683-2692.

(2) (a) Chun, S. W.; Hinze, M. E.; Skiba, M. A.; Narayan, A. R. H. J. Am. Chem. Soc. 2018, 140, 2430-2433. (b) Tian, C.-S.; Jiao, X.-Z.; Liu, X.-Y.; Li, R.-Z.; Dong, L.; Liu, X.-J.; Zhang, Z.-G.; Xu, J.; Xu, M.-J.; Xie, P. Tetrahedron Lett. 2012, 53, 4892-4895.

(3) (a) Kieser, T.; Bibb, M. J.; Buttner, M. J.; Chater, K. F.; Hopwood, D. A. Practical Streptomyces Genetics; John Innes Foundation Norwich, 2000. (b) Sambrook, J.; Russel, D. Molecular Cloning: a Laboratory Manual.; Cold Spring Harbour. PP, 2001.

(4) He, Y.-L.; Wang, Z.-J.; Bai, L.-Q.; Liang, J.-D.; Zhou, X.-F.; Deng, Z.-X. J Microbiol. Biotechnol. 2010, 20, 678-682.

(5) Gibson, D. G.; Benders, G. A.; Andrews-Pfannkoch, C.; Denisova, E. A.; Baden-Tillson, H.; Zaveri, J.; Stockwell, T. B.; Brownley, A.; Thomas, D. W.; Algire, M. A.; Merryman, C.; Lei, Y.; Noskov, V. N.; Glass, J. I.; Venter, J. C.; Hutchison III, C. A.; Smith, H. O. Science 2008, 319, 1215-1220.

(6) Xu, J.-J.; Zhang, J.-H.; Zhuo, J.-M.; Li, Y.; Tian, Y.-Q.; Tan, H.-R. J. Biol. Chem. 2017, 292, 19708-19720.

(7) Jones, D. T.; Taylor, W. R.; Thornton, J. M. CABIOS, Comput. Appl. Biosci. 1992, 8, 275-282.

(8) Felsenstein, J. Evolution 1985, 39, 783-791.

(9) Zhang, H.-K.; Gao, S.-H.; Lercher, M. J.; Hu S.-N.; Chen, W.-H. Nucleic Acids Res. 2012, 40, W569-W572.

(10) Pinon, V.; Ravanel, S.; Douce, R.; Alban, C. Plant Physiol. 2005, 139, 1666-1676.

(11) Webster, S. P.; Alexeev, D.; Campopiano, D. J.; Watt, R. M.; Alexeeva, M.; Sawyer, L.; Baxter, R. L. Biochemistry 2000, 39, 516-528.

(12) Kumar, S.; Stecher, G.;Tamura, K. J. M. B. Mol. Biol. Evol. 2016, 33, 1870-1874.

(13) Teng, C.; Dong, H.-L.; Shi, L.-H.; Deng, Y.; Mu, J.-Y.; Zhang, J.; Yang, X.-H.; Zuo, J.-R. Plant Physiol. 2008, 146, 1322-1332.

(14) Ferreira, G. C.; Dailey, H. A. J. Biol. Chem. 1993, 268, 584-590.

(15) Schmidt, A.; Sivaraman, J.; Li, Y.; Larocque, R.; Barbosa, J. A. R. G.; Smith, C.; Matte, A.; Schrag, J. D.; Cygler, M. Biochemistry 2001, 40, 5151-5160.

(16) (a) Kelly, R. C.; Bolitho, M. E.; Higgins, D. A.; Lu, W.-Y.; Ng, W.-L.; Jeffrey, P. D.; Rabinowitz, J. D.; Semmelhack, M. F.; Hughson, F. M.; Bassler, B. L. Nat. Chem. Biol. 2009, 5, 891-895. (b) Wei, Y.-Z.; Perez, L. J.; Ng, W.-L.; Semmelhack, M. F.; Bassler, B. L. ACS Chem. Biol. 2011, 6, 356-365.

(17) Kawata, J.; Naoe, T.; Ogasawara, Y.; Dairi, T. Angew. Chem. 2017, 129, 2058-2061.

(18) Masuo, S.; Tsuda, Y.; Namai, T.; Minakawa, H.; Shigemoto, R.; Takaya, N. ChemBioChem. 2020, 21, 353-359.

(19) Gerber, R.; Lou, L.-L.; Du, L.-C. J. Am. Chem. Soc. 2009, 131, 3148-3149.

(20) Mo, S.; Sydor, P. K.; Corre, C.; Alhamadsheh, M. M.; Stanley, A. E.; Haynes, S. W.; Song, L.-J.; Reynolds, K. A.; Challis, G. L. Cell Chem. Biol. 2008, 15, 137-148.

(21) Zhao, Z.-L.; Shi, T.; Xu, M.; Brock, N. L.; Zhao, Y.-L.; Wang, Y.-M.; Deng, Z.-X.; Pang, X.-H.; Tao, M.-F. Org. Lett. 2016, 18, 572-575. 
(22) Hornung, C.; Poehlein, A.; Haack, F. S.; Schmidt, M.; Dierking, K.; Pohlen, A.; Schulenburg, H.; Blokesch, M.; Plener, L.; Jung, K.; Bonge, A.; Krohn-Molt, I.; Utpatel, C., Timmermann, G.; Spieck, E.; Pommerening-Röser, A.; Bode, E.; Bode, H. B.; Daniel, R.; Schmeisser, C.; Streit, W. R. PLoS one 2013, 8, e55045.

(23) Dai, G.-Z.; Han, W.-B.; Mei, Y.-N.; Xu, K.; Jiao, R.-H.; Ge, H.-M.; Tan, R.-X. Proc. Natl. Acad. Sci. U. S. A. 2020, 117, 1174-1180.

(24) Zhang, W.-J.; Bolla, M. L.; Kahne, D.; Walsh, C. T. J. Am. Chem. Soc. 2010, 132, 6402-6411.

(25) Bierman, M.; Logan, R.; O’brien, K.; Seno, E. T.; Rao, R. N.; Schoner, B. E. Gene 1992, 116, 43-49.

(26) Li, X.-L.; Xu, M.-J.; Zhao, Y.-L.; Xu, J. Molecules 2010, 15, 9298-9307. 